\title{
Ketamine and Ketamine Metabolite Pharmacology: Insights into Therapeutic Mechanisms
}

\author{
Panos Zanos, Ruin Moaddel, Patrick J. Morris, Lace M. Riggs, Jaclyn N. Highland, Polymnia Georgiou, Edna F. R. Pereira, \\ Edson X. Albuquerque, Craig J. Thomas, Carlos A. Zarate, Jr., and Todd D. Gould
}

Departments of Psychiatry (P.Z., L.M.R., J.N.H., P.G., T.D.G.), Pharmacology (E.F.R.P., E.X.A., T.D.G.), Anatomy and Neurobiology (T.D.G.), Epidemiology and Public Health, Division of Translational Toxicology (E.F.R.P., E.X.A.), Medicine (E.X.A.), and Program in Neuroscience (L.M.R.) and Toxicology (J.N.H.), University of Maryland School of Medicine, Baltimore, Maryland; Biomedical Research Center, National Institute on Aging, Intramural Research Program, National Institutes of Health, Baltimore, Maryland (R.M.); Division of Preclinical Innovation, National Center for Advancing Translational Sciences, Intramural Research Program, National Institutes of Health,

Rockville, Maryland (P.J.M., C.J.T.); and Experimental Therapeutics and Pathophysiology Branch, Intramural Research Program, National Institute of Mental Health, National Institutes of Health, Bethesda, Maryland (C.A.Z.)

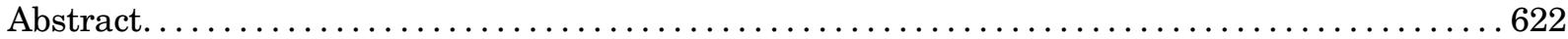

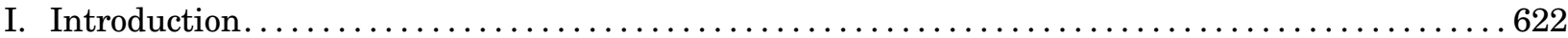

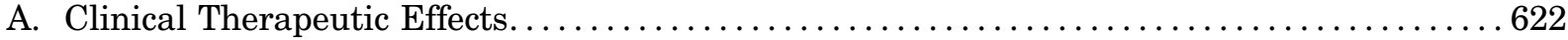

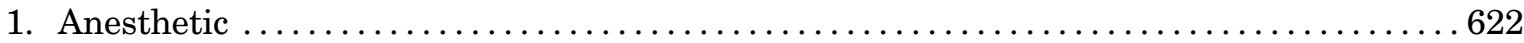

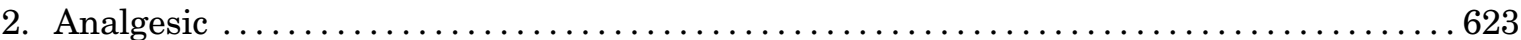

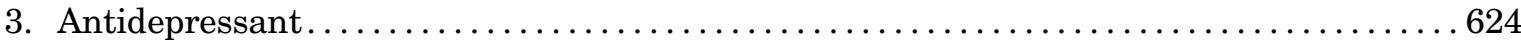

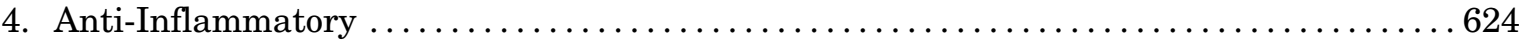

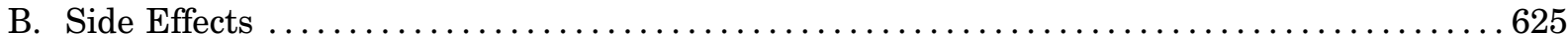

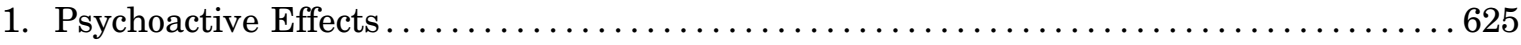

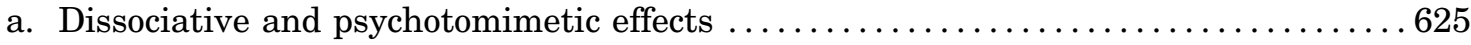

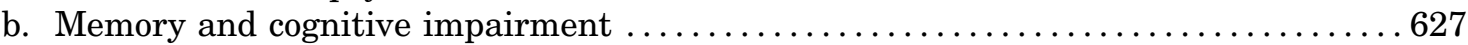

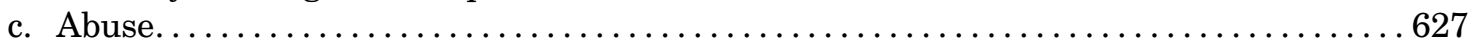

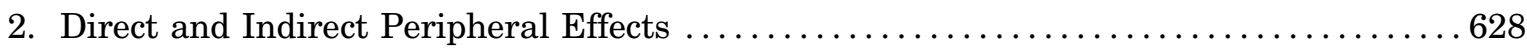

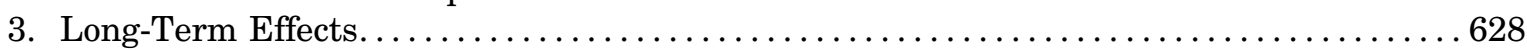

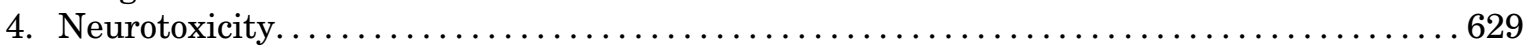

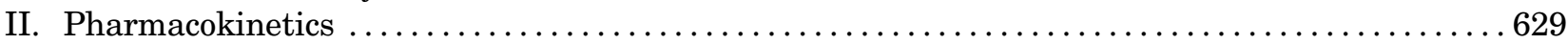

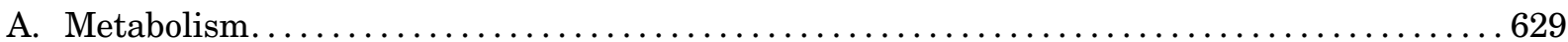

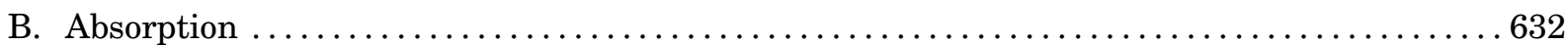

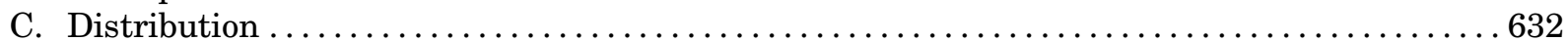

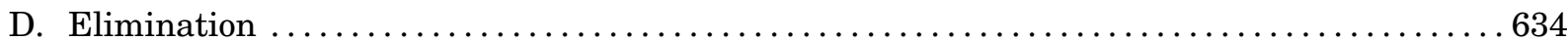

III. Pharmacodynamics of Ketamine and Its Metabolites . . . . . . . . . . . . . . . . . . . . 635

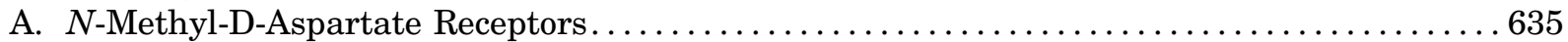

B. Hyperpolarization-Activated Cyclic Nucleotide-Gated Channels . . . . . . . . . . . . . . 645

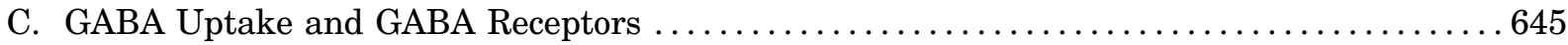

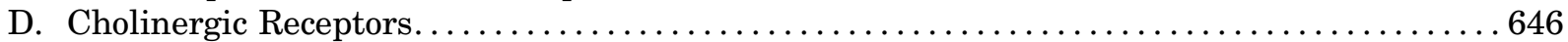

Address correspondence to: Dr. Todd D. Gould, Department of Psychiatry, University of Maryland School of Medicine, Room 936 MSTF, 685 West Baltimore Street, Baltimore, MD 21201. E-mail: gouldlab@me.com

This work is supported by a National Institutes of Health (NIH) Grant MH107615 and a Harrington Discovery Institute Scholar-Innovator Grant to T.D.G., a National Association for Research on Schizophrenia and Depression Young Investigator Award to P.Z., and the National Institute of Aging (R.M.), National Institute of Mental Health (C.A.Z.), and National Center for Advancing Translational Sciences (C.J.T.) NIH intramural research programs.

The authors declare competing financial interests: R.M. and C.A.Z. are listed as coinventors on a patent for the use of $(2 R, 6 R)$-hydroxynorketamine, $(S)$-dehydronorketamine, and other stereoisomeric dehydro- and hydroxylated metabolites of $(R, S)$-ketamine in the treatment of depression and neuropathic pain. P.Z., R.M., P.J.M., C.J.T., C.A.Z., and T.D.G. are listed as coinventors on a patent application for the use of (2R,6R)hydroxynorketamine and $(2 S, 6 S)$-hydroxynorketamine in the treatment of depression, anxiety, anhedonia, suicidal ideation, and post-traumatic stress disorders. R.M., P.J.M., C.A.Z., and C.J.T. have assigned their patent rights to the U.S. government but will share a percentage of any royalties that may be received by the government. P.Z. and T.D.G. have assigned their patent rights to the University of Maryland, Baltimore, but will share a percentage of any royalties that may be received by the University of Maryland, Baltimore. All other authors declare no competing interests.

https://doi.org/10.1124/pr.117.015198. 


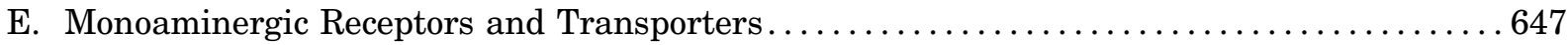

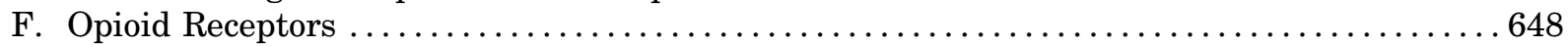

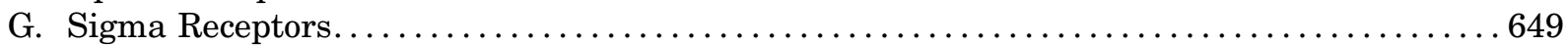

H. Voltage-Gated Sodium Channels ..................................... 650

I. L-Type Voltage-Dependent Calcium Channels .......................... 650

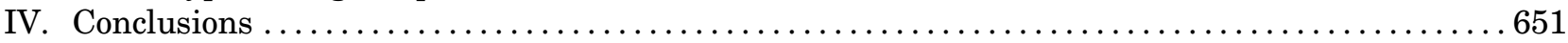

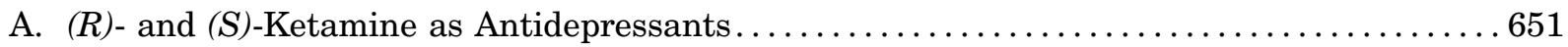

B. Utility of Ketamine's Hydroxynorketamine Metabolites as Drug Treatments ..........6 652

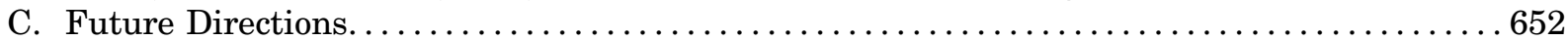

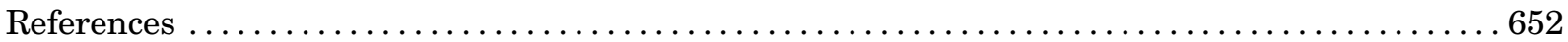

\begin{abstract}
Ketamine, a racemic mixture consisting of $(S)$ - and $(R)$-ketamine, has been in clinical use since 1970. Although best characterized for its dissociative anesthetic properties, ketamine also exerts analgesic, anti-inflammatory, and antidepressant actions. We provide a comprehensive review of these therapeutic uses, emphasizing drug dose, route of administration, and the time course of these effects. Dissociative, psychotomimetic, cognitive, and peripheral side effects associated with short-term or prolonged exposure, as well as recreational ketamine use, are also discussed. We further describe ketamine's pharmacokinetics, including its rapid and extensive metabolism to norketamine, dehydronorketamine, hydroxyketamine, and hydroxynorketamine (HNK) metabolites. Whereas the anesthetic and analgesic properties of ketamine are generally attributed to direct ketamine-induced inhibition of
\end{abstract}

$N$-methyl-D-aspartate receptors, other putative loweraffinity pharmacological targets of ketamine include, but are not limited to, $\gamma$-amynobutyric acid (GABA), dopamine, serotonin, sigma, opioid, and cholinergic receptors, as well as voltage-gated sodium and hyperpolarization-activated cyclic nucleotide-gated channels. We examine the evidence supporting the relevance of these targets of ketamine and its metabolites to the clinical effects of the drug. Ketamine metabolites may have broader clinical relevance than was previously considered, given that HNK metabolites have antidepressant efficacy in preclinical studies. Overall, pharmacological target deconvolution of ketamine and its metabolites will provide insight critical to the development of new pharmacotherapies that possess the desirable clinical effects of ketamine, but limit undesirable side effects.

\section{Introduction}

$(R, S)$-Ketamine (hereafter referred to as ketamine) is a phenylcyclohexylamine derivative (mol. wt. $=237.73)$ consisting of its two optical enantiomers, $(S)$ - and $(R)$ ketamine (Adams et al., 1978). It became commercially available for human use in 1970 as a rapid-acting i.v. anesthetic (Dundee et al., 1970). Ketamine was derived from phencyclidine (PCP) with the aim of lessening the serious psychotomimetic/psychodysleptic side effects and abuse potential of the parent drug, which was subsequently removed from the market in 1978 (Mion and Villevieille, 2013). However, ketamine still induces dissociative effects (Domino et al., 1965; Erdemir et al., 1970; Oye et al., 1992; Krystal et al., 1994; Bowdle et al., 1998; Newcomer et al., 1999; Lahti et al., 2001; Pomarol-Clotet et al., 2006) and has abuse potential (Siegel, 1978; Reich and Silvay, 1989; Dalgarno and Shewan, 1996; Stewart, 2001; Morgan and Curran, 2012), although to a lesser extent than PCP. Despite these side effects, ketamine has proven to be a desirable drug due to its short half-life and lack of clinicallysignificant respiratory depression (Clements et al., 1982; Gorlin et al., 2016). In addition to its well-characterized anesthetic action in adults, children, and obstetric patients, ketamine possesses analgesic effects (Weisman, 1971), antiinflammatory effects (Roytblat et al., 1998), and antidepressant activity (Berman et al., 2000; Zarate et al., 2006; also see Wolff and Winstock, 2006).

\section{A. Clinical Therapeutic Effects}

1. Anesthetic. Ketamine induces general, dissociative anesthesia in animals (McCarthy et al., 1965; Chen et al., 1966; Bree et al., 1967) and humans (Domino et al., 1965; Corssen and Domino, 1966; Virtue et al., 1967; Miyasaka and Domino, 1968; Domino, 2010). Moreover, ketamine is also used as an adjunct to local anesthetics in veterinary practice and in humans (Green et al., 1981; Bion, 1984; Gomez de Segura et al., 1998; Hawksworth and Serpell, 1998; Kathirvel et al., 2000).

Dissociative anesthesia- a form of anesthesia that lacks complete unconsciousness but is characterized by catatonia, catalepsy, and amnesia-is achieved in humans at ketamine doses ranging from 1 to $2 \mathrm{mg} / \mathrm{kg}$ administered i.v. (bolus) or $4-11 \mathrm{mg} / \mathrm{kg}$ administered i.m. (Sage and Laird, 1972; Sussman, 1974; Dachs and

ABBREVIATIONS: $\sigma_{1} \mathrm{R}$, sigma I receptor; $\sigma_{2} \mathrm{R}$, sigma II receptor; AMPA, $\alpha$-amino-3-hydroxy-5-methyl-4-isoxazolepropionic acid; AUC, area under the curve; CHO, Chinese hamster ovary; CRPS, complex regional pain syndrome; $\mathrm{D}_{2} \mathrm{R}, \mathrm{D}_{2}$ receptor; DA, dopamine; DHNK, dehydronorketamine; HCN, hyperpolarization-activated cyclic nucleotide-gated channel; HEK, human embryonic kidney; HK, hydroxyketamine; HNK, hydroxynorketamine; 5-HT, serotonin; IL-6, interleukin 6; mAChR, muscarinic acetylcholine receptor; nAChR, nicotinic acetylcholine receptor; NET, norepinephrine transporter; NMDAR, $N$-methyl-D-aspartate receptor; PCP, phencyclidine; PET, positron emission tomography; SERT, serotonin transporter; VDCC, voltage-dependent calcium channel. 
Innes, 1997; Weber et al., 2004; Green et al., 2011; Gao et al., 2016). Peak ketamine plasma concentrations of approximately $1200-2400 \mathrm{ng} / \mathrm{ml}$, or $5-10 \mu \mathrm{M}$, are necessary to induce dissociative anesthesia (Little et al., 1972; Idvall et al., 1979; Grant et al., 1983).

The average steady-state plasma concentration necessary to achieve anesthesia with ketamine was reported to be $2200 \mathrm{ng} / \mathrm{ml}$, or $9.3 \mu \mathrm{M}$ (Idvall et al., 1979). Oral (500 mg; Craven, 2007) or intrarectal $(8-15 \mathrm{mg} / \mathrm{kg}$; Idvall et al., 1983; Malaquin, 1984; Malinovsky et al., 1996) administration of ketamine are sufficient to induce sedation and/or general anesthesia in humans.

Awakening from ketamine-induced anesthesia occurs at plasma concentrations ranging from 640 to $1100 \mathrm{ng} / \mathrm{ml}$ or 2.7-4.7 $\mu \mathrm{M}$ (Idvall et al., 1979; Reich and Silvay, 1989). White et al. (1985) showed that administration of the racemic mixture of ketamine (5- to 7 -minute i.v. infusion of $50 \mathrm{mg} / \mathrm{min}$ for a total dose of $275 \pm 25 \mathrm{mg}$ ) induced general anesthesia in five healthy adult volunteers, as indicated by the absence of an eyelid reflex. Upon termination of the infusion, it took approximately $11 \pm 3$ minutes for the volunteers to open their eyes $(1900-3300 \mathrm{ng} / \mathrm{ml}$ or $8.0-14 \mu \mathrm{M}$ serum concentration), and approximately $45 \pm 10$ minutes for them to fully regain proper orientation of self, place, and time (3.78-4.62 $\mu \mathrm{M}$ serum concentration; White et al., 1985).

Intranasal $(S)$-ketamine at the doses of $3-9 \mathrm{mg} / \mathrm{kg}$ induces sedation in patients (Tsze et al., 2012). As an anesthetic for humans, $(S)$-ketamine is reported to be twice as potent as the racemic mixture and approximately three times more potent than $(R)$-ketamine (White et al., 1985; Schüttler et al., 1987; Himmelseher and Pfenninger, 1998). Specifically, the total i.v. dose required for the induction of anesthesia is $275 \pm 25 \mathrm{mg}$ for racemic ketamine, $140 \pm 21 \mathrm{mg}$ for $(S)$-ketamine, and $429 \pm 37 \mathrm{mg}$ for $(R)$-ketamine (White et al., 1985). Time needed to regain complete orientation of self, place, and time following a 5- to 7-minute i.v. administration of $(S)$-ketamine $(25 \mathrm{mg} / \mathrm{min}$; total dose: $140 \pm 21 \mathrm{mg})$ or $(R)$-ketamine $(75 \mathrm{mg} / \mathrm{min}$; total dose: $429 \pm 37 \mathrm{mg})$ was $21 \pm 2$ minutes $(500-900 \mathrm{ng} / \mathrm{ml}$ or 2.1-3.8 $\mu \mathrm{M}$ serum concentration) and $18 \pm 3$ minutes (2200-3200 $\mathrm{ng} / \mathrm{ml}$ or $9.3-13 \mu \mathrm{M}$ serum concentration), respectively (White et al., 1985). These data indicate that the $(S)$-ketamine isomer is a more potent anesthetic compared with $(R)$-ketamine, given that a threefold higher dose of $(R)$-ketamine is required to elicit a comparable level of sedation. Additionally, the serum concentration of $(R)$-ketamine that caused half-maximal median frequency decrease $\left(\mathrm{IC}_{50}\right)$ in electroencephalographic oscillations was measured to be $2000 \pm$ $500 \mathrm{ng} / \mathrm{ml}(8.0 \pm 2.0 \mu \mathrm{M})$, versus $1800 \pm 500 \mathrm{ng} / \mathrm{ml}$ $(7.6 \pm 2.0 \mu \mathrm{M})$ for the racemic drug and $800 \pm$ $400 \mathrm{ng} / \mathrm{ml}(3.4 \pm 1.7 \mu \mathrm{M})$ for the $(S)$-ketamine isomer (Schüttler et al., 1987).
2. Analgesic. An early report of the analgesic effects of ketamine was provided by Weisman (1971), who observed these effects in pediatric ophthalmologic procedures (Weisman, 1971). Ketamine is described to provide a form of analgesia quantitatively and qualitatively similar to opioids, but with less respiratory depressive effects, as was reported in pediatric patients treated for fractures (Kennedy et al., 1998), burns (see McGuinness et al., 2011), or in cases of traumatic amputation (Bonanno, 2002). When administered i.v. or i.m., ketamine's analgesic effects are associated with plasma concentrations ranging between 70 and $160 \mathrm{ng} / \mathrm{ml}$, or approximately $0.29-0.67 \mu \mathrm{M}$ (Clements and Nimmo, 1981; Grant et al., 1981; Clements et al., 1982; Flood and Krasowski, 2000).

Intravenous ketamine is used as an analgesic to reduce chronic and acute postoperative pain (Laskowski et al., 2011). Adequate analgesia is achieved at subanesthetic doses of ketamine, as low as $0.15-0.25 \mathrm{mg} / \mathrm{kg}$, when administered i.v. (Roytblat et al., 1993; Backonja et al., 1994; Eide et al., 1994), or $0.5-1 \mathrm{mg} / \mathrm{kg}$ when administered i.m. to patients following acute trauma (Hirlinger and Dick, 1984). In addition, ketamine's antinociceptive and analgesic effects have been observed when ketamine is administered as follows: 1) orally at the dose of $0.5 \mathrm{mg} / \mathrm{kg}$ twice per day for 15 days (as adjuvant to morphine; Lauretti et al., 1999) or at the single dose of $2 \mathrm{mg} / \mathrm{kg}$ (Marchetti et al., 2015); 2) intranasally at a dose ranging from 10 to $50 \mathrm{mg}$ twice per day (Carr et al., $2004)$; 3) transdermally at the dose of $25 \mathrm{mg}$ released throughout a 24-hour period (Azevedo et al., 2000); 4) s.c. at a dose ranging from 0.05 to $0.15 \mathrm{mg} / \mathrm{kg}$ per hour for 7 days (Eide et al., 1995); and 5) rectally at the dose of $10 \mathrm{mg} / \mathrm{kg}$ (Tanaka et al., 2000). Following oral dosing, lower ketamine concentrations in the blood may be required to achieve analgesia compared with the other routes of administration (maximum concentration, $\mathrm{C}_{\max }=45 \pm 10 \mathrm{ng} / \mathrm{ml}$ or $0.19 \pm 0.04 \mu \mathrm{M}$; Grant et al., 1981). Continuous infusion of a subanesthetic dose of ketamine (titrated from 10 to $40 \mathrm{mg} / \mathrm{h}$; maintained for 5 days) has been demonstrated to be effective in improving pain in patients suffering from complex regional pain syndrome (CRPS), resulting in plasma concentrations of both $(S)$ - and $(R)$-ketamine ranging between 200 and $225 \mathrm{ng} / \mathrm{ml}(0.84-0.95 \mu \mathrm{M}$; Goldberg et al., 2010; Moaddel et al., 2010).

The use of intranasal $(S)$-ketamine as an analgesic may be of particular relevance in prehospital settings, where i.v. administration is difficult, and in cases where acute administration for injuries is required, because it reduces pain scores within 5 minutes following administration (Johansson et al., 2013). Similar to their differential anesthetic effects, there is evidence supporting that $(S)$-ketamine is a more potent analgesic drug compared with racemic ketamine and $(R)$-ketamine in humans, although $(S)$-ketamine also 
produces more side effects (Oye et al., 1992; Mathisen et al., 1995).

3. Antidepressant. Evidence of ketamine's antidepressant actions dates back to the 1970s. In preclinical studies, ketamine was found to exert effects similar to those observed following administration of classic antidepressant drugs (i.e., tricyclic antidepressants and monoamine oxidase inhibitors) in rodents (Sofia and Harakal, 1975). In particular, oral administration of ketamine to mice reversed reserpine-induced hyperthermia at the dose of $40 \mathrm{mg} / \mathrm{kg}$ and prevented tetrabenazineinduced ptosis with an $\mathrm{ED}_{50}$ of $27.6 \mathrm{mg} / \mathrm{kg}$ (Sofia and Harakal, 1975), which are phenotypes reversed by classical antidepressants (Delini-Stula, 1980). Early evidence of ketamine's possible antidepressant properties in humans was described in 1973 by Khorramzadeh and Lotfy (1973), who reported that i.v. ketamine at the subanesthetic doses of $0.2-1.0 \mathrm{mg} / \mathrm{kg}$ (i.v. bolus) resulted in emotional discharge and facilitation of psychotherapy in a cohort of 100 psychiatric inpatients. However, the precise depression symptoms that were improved with ketamine were not well delineated in the context of modern diagnostic criteria and therapeutic definitions. In this study, ketamine was in fact referred to as a general abreactive agent (Khorramzadeh and Lotfy, 1973).

The first placebo-controlled study suggesting ketamine has antidepressant actions was reported in 2000 . Based on the results reported in that study, an i.v. 40 -minute infusion of $0.5 \mathrm{mg} / \mathrm{kg}$ ketamine induced a robust and rapid antidepressant response in patients suffering from depression compared with placebo (Berman et al., 2000). This finding was subsequently replicated in a double-blind, placebo-controlled, randomized clinical trial involving patients suffering from treatment-refractory major depression (Zarate et al., 2006). In particular, Zarate et al. (2006) demonstrated that ketamine exerts an antidepressant effect that becomes evident within 2 hours postinfusion, and lasts for an average of 7 days in patients who have failed to respond to at least two prior classical antidepressant medications. Several other clinical trials have replicated these findings in patients suffering from treatmentrefractory depression (e.g., Murrough et al., 2013a; Lapidus et al., 2014). To address the functional unblinding of treatment status due to the dissociative effects of ketamine, which occur even at low subanesthetic doses, Murrough et al. (2013a) used a psychoactive placebo (i.e., midazolam) and demonstrated a higher response rate for the patients who received ketamine (64\%) compared with those who received midazolam (28\%). Ketamine is also reported to exert antidepressant actions in patients suffering from bipolar depression (Diazgranados et al., 2010a; Zarate et al., 2012b). (S)ketamine has been shown effective as an antidepressant administered both via i.v. and intranasal routes (Singh et al., 2016a; Daly et al., 2018; Canuso et al., 2018).
Additional studies have shown that ketamine reduces suicidal ideation (Price et al., 2009; DiazGranados et al., 2010b; Ballard et al., 2014) and decreases anhedonia (Lally et al., 2014, 2015; Ballard et al., 2017) in patients suffering from major depression. Intranasal $(S)$-ketamine also decreased suicidal ideation in patients suffering from depression (Canuso et al., 2018).

The most commonly used subanesthetic antidepressant dose of ketamine $(0.5 \mathrm{mg} / \mathrm{kg} ; 40$-minute infusion) results in a maximal plasma concentration $\left(\mathrm{C}_{\max }\right)$ of $\sim 185 \mathrm{ng} / \mathrm{ml}$ or $\sim 0.78 \mu \mathrm{M}$ ketamine, as calculated from the results of Zarate et al. (2012a). Nevertheless, there is some evidence for antidepressant responses achieved at doses as low as $0.1 \mathrm{mg} / \mathrm{kg}$ (5-minute i.v. infusion or i.m. injection), resulting in ketamine $\mathrm{C}_{\max }$ of $\sim 75 \mathrm{ng} / \mathrm{ml}(0.32 \mu \mathrm{M}$-estimated $)$ as reported in a small pilot ( $n=15$ ) double-blind, placebo-controlled crossover study in patients suffering from treatmentresistant depression (Loo et al., 2016). Although this study indicated that lower doses of ketamine, which produce fewer side effects, could be effective in the treatment of depression, this finding awaits replication in a larger study.

4. Anti-Inflammatory. Inflammation is a critical homeostatic mechanism used by the body to fight infections and to heal tissue injuries (Selye, 1976; Hirsiger et al., 2012). Inflammatory reactions are triggered once immune cells of the innate immune system become activated, whether by invading pathogens or tissue damage. Release of proinflammatory cytokines by these cells then activate members of the adaptive immune system to initiate an inflammatory response (Newton and Dixit, 2012).

Ketamine administration during or prior to surgical operations has been used for a more favorable postoperative outcome, primarily due to its actions to reduce the production of excess proinflammatory cytokines. Anti-inflammatory actions (i.e., reduction of proinflammatory cytokines) of preoperative subanesthetic doses of $0.15-0.25 \mathrm{mg} / \mathrm{kg}$ (single i.v. bolus) ketamine were described in humans (Roytblat et al., 1998; Beilin et al., 2007; Russabrov et al., 2008). Ketamine was shown to inhibit immune reaction-induced proinflammatory cytokine production, including nuclear factor $\kappa \mathrm{B}$, and to decrease blood levels of tumor necrosis factor- $\alpha$, interleukin 6 (IL-6), C-reactive protein, and/or inducible nitric oxide synthase (Larsen et al., 1998; Kawasaki et al., 1999, 2001; Lankveld et al., 2005; Beilin et al., 2007; Loix et al., 2011; De Kock et al., 2013). The ability of ketamine to reduce proinflammatory cytokine levels may be of clinical relevance, given that elevated IL-6 levels have been associated with poor postoperative outcomes (Oka et al., 1992; Hennein et al., 1994; Cremer et al., 1996). However, this possibility awaits systematic investigation.

In addition to its effects on the proinflammatory cytokines, ketamine dose dependently reduces inflammation-induced 
nitric oxide production (Shimaoka et al., 1996; Li et al., 1997; Yang et al., 2005). The anti-inflammatory effects of ketamine have been observed when the drug was administered prior to, and following an immune stimulation, indicating that ketamine may be able to prevent exacerbation of inflammation, and also reduce existing inflammation (Loix et al., 2011). There is evidence that ketamine can alleviate postoperative trauma-induced hyperalgesia by modulating the inflammatory response, which is beneficial in the context of chronic postoperative pain (Stubhaug et al., 1997; De Kock et al., 2001; Suzuki et al., 2006; Remerand et al., 2009).

Ketamine has also been shown to correct abnormal inflammatory bone markers in major depressive disorder. In particular, a 40-minute i.v. infusion of ketamine $(0.5 \mathrm{mg} / \mathrm{kg})$ increased levels of the osteoprotegerin receptor activator of nuclear factor $\kappa \mathrm{B}$ ligand and osteopontin-predictive markers of bone inflammationin patients with major depressive disorder, but had no effect in healthy controls (Kadriu et al., 2017). Moreover, serum levels of the proinflammatory cytokines tumor necrosis factor- $\alpha$, interferon $\gamma$, and interleukin 2 , 5 , and 10 were unaltered following a 40 -minute i.v. subanesthetic infusion of ketamine $(0.5 \mathrm{mg} / \mathrm{kg})$ in patients suffering from depression, whereas levels of the anti-inflammatory cytokine IL- 6 were reported to increase 230 minutes postketamine infusion (Park et al., 2017). However, this effect of ketamine on IL-6 levels was not associated with the antidepressant actions of the drug (Park et al., 2017). It is possible that the infusion itself led to an acute stress-related increase in IL-6 levels, given that this has been observed following saline infusion as well (Cho et al., 2009). Overall, these findings indicate that the anti-inflammatory actions of ketamine occur primarily in the presence of immunostimulation, whereas the drug does not exert any effects on cytokine balance in the absence of an inflammatory reaction (Loix et al., 2011). Thus, ketamine may act as an immunomodulator, and not as an immunosuppressive agent, which is of particular importance because ketamine is commonly administered during the induction of anesthesia, prior to surgery.

Relevant doses and plasma concentrations of ketamine used for clinical therapeutic effects are listed in Table 1.

\section{B. Side Effects}

\section{Psychoactive Effects.}

a. Dissociative and psychotomimetic effects. Ketamine dose dependently exerts broad influences on consciousness and perception, with some patients reporting dissociative and extracorporeal sensations (out-of-body experiences/illusions) when recovering from ketamine-induced anesthesia (Garfield et al., 1972; White et al., 1980, 1982). Whereas these effects of ketamine established the drug as a dissociative anesthetic (Domino et al., 1965), the same effects have been noted following subanesthetic doses as well (e.g., Krystal et al., 1994).

The most common psychoactive effects reported after a single subanesthetic i.v. administration of ketamine include dissociation (distortions in visual, auditory, or somatosensory stimuli, or alterations in the perception of self or time), positive psychotomimetic effects (conceptual disorganization, hallucinations, suspiciousness, unusual thought content), and negative psychotomimetic effects (blunted affect, emotional withdrawal, motor retardation). These effects were reported in both randomized controlled studies (e.g., Malhotra et al., 1996; Anand et al., 2000; Berman et al., 2000; Hetem et al., 2000; Abel et al., 2003; Zarate et al., 2006; Diazgranados et al., 2010a; Zarate et al., 2012b; Murrough et al., 2013b, 2015; Downey et al., 2016; Hu et al., 2016; Li et al., 2016) and nonrandomized or open label studies (e.g., Phelps et al., 2009; Mathew et al., 2010; Valentine et al., 2011; Ibrahim et al., 2012; Ionescu et al., 2015). For instance, a randomized, double-blind, placebo-controlled study by Krystal et al. (1994) showed that a 40-minute i.v. infusion of the subanesthetic dose of $0.5 \mathrm{mg} / \mathrm{kg}$ ketamine (resulting $\mathrm{C}_{\max }$ estimated to be $\sim 100-250 \mathrm{ng} / \mathrm{ml}$ or $0.42-1.1 \mu \mathrm{M}$ ) leads to perceptual aberrations that are consistent with dissociative states, as well as positive and negative psychotomimetic symptoms. These effects emerged within 10 minutes of the beginning of ketamine infusion and subsided within 40 minutes of treatment termination. In contrast, little to no psychoactive effects were observed at the dose of $0.1 \mathrm{mg} / \mathrm{kg}$ (resulting in $\sim 25-50 \mathrm{ng} / \mathrm{ml}$ or $0.1-0.2 \mu \mathrm{M}$ plasma ketamine concentration; Krystal et al., 1994). Ketamine $\left(0.3 \mathrm{mg} / \mathrm{kg}\right.$ bolus; $\mathrm{C}_{\max }=\sim 120 \mathrm{ng} / \mathrm{ml}$ or $\left.0.5 \mu \mathrm{M}\right)$ has also been shown to exacerbate psychotic symptoms in patients suffering from schizophrenia (Lahti et al., 2001). Similarly, Malhotra et al. (1997) also reported that ketamine increased psychotic symptoms in patients suffering from schizophrenia when given as a single i.v. bolus of $0.12 \mathrm{mg} / \mathrm{kg}$, followed by a 60 -minute infusion of $0.65 \mathrm{mg} / \mathrm{kg}$ (total dose $0.77 \mathrm{mg} / \mathrm{kg}$ ).

Experiencing illusions and alterations in hearing, vision, and proprioception has been attributed to the actions of $(S)$-ketamine (Oye et al., 1992; Mathisen et al., 1995; Vollenweider et al., 1997), whereas feelings of relaxation were associated with the actions of $(R)$ ketamine (Vollenweider et al., 1997). In particular, at equimolar doses producing average plasma ketamine levels of $379 \pm 71 \mathrm{ng} / \mathrm{mg}$ (i.e., $1.59 \pm 0.30 \mu \mathrm{M}$ ) and $389 \pm$ $74 \mathrm{ng} / \mathrm{mg}$ (i.e., $1.64 \pm 0.31 \mu \mathrm{M})$ for $(S)$ - and $(R)$-ketamine, respectively, the $(S)$-ketamine enantiomer caused acute psychotic reactions at a mean plasma ketamine level of $539 \mathrm{ng} / \mathrm{ml}$ (i.e., $2.27 \mu \mathrm{M}$ ), whereas $(R)$-ketamine was not associated with these psychotomimetic actions. In contrast, $(R)$-ketamine administration induced a feeling of 


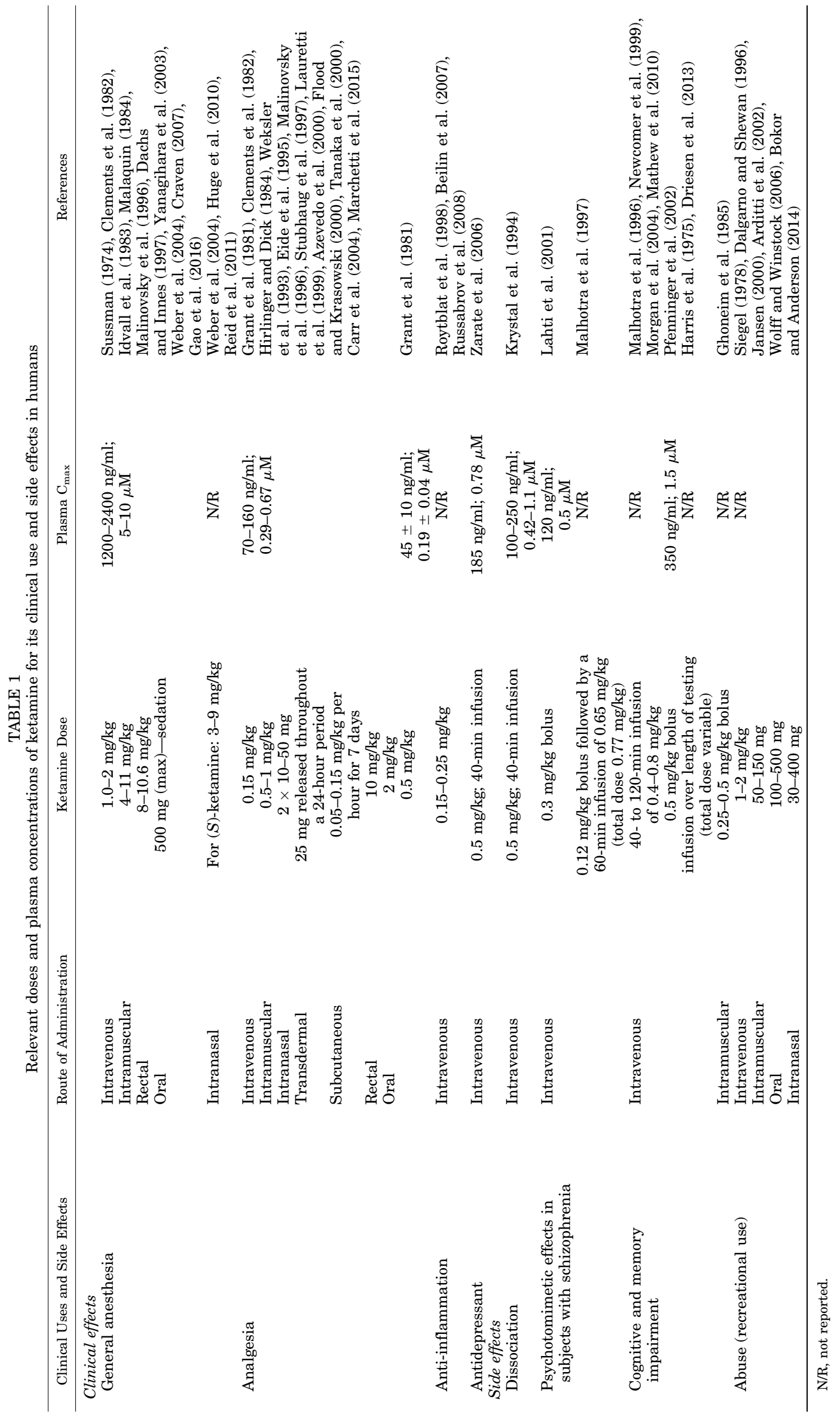


"well-being" and a beneficial effect on mood as measured by the Eigenschaftsworterliste (EWL) mood rating scale (Vollenweider et al., 1997). A clinical study conducted by Mathisen et al. (1995) showed that $56 \%$ of patients who suffered from orofacial pain and were treated with $(S)$ ketamine $\left(0.45 \mathrm{mg} / \mathrm{kg}\right.$, i.m.; serum $\mathrm{C}_{\max }=\sim 120 \mathrm{ng} / \mathrm{ml}$ or $0.5 \mu \mathrm{M})$ experienced illusions, whereas only $22 \%$ of those treated with $(R)$-ketamine experienced illusions, even though a higher dose of $(R)$-ketamine was used $\left(1.8 \mathrm{mg} / \mathrm{kg}\right.$, i.m.; serum $\mathrm{C}_{\max }=\sim 590 \mathrm{ng} / \mathrm{ml}$ or $\left.2.5 \mu \mathrm{M}\right)$. In this study, the prevalence of illusions among patients treated with $(S)$-ketamine was comparable to that observed among patients treated with $(R, S)$-ketamine at a dose of $0.9 \mathrm{mg} / \mathrm{kg}$, i.m.; serum $\mathrm{C}_{\max }=\sim 297 \mathrm{ng} / \mathrm{ml}$ or $1.25 \mu \mathrm{M}$ (Mathisen et al., 1995). Alterations in hearing were reported in $78 \%, 67 \%$, and $57 \%$ of patients treated with $(S)-,(R)$-, and $(R, S)$-ketamine, respectively, whereas blurred vision was reported by $100 \%, 78 \%$, and $85 \%$ of patients receiving $(S)$-, $(R)$-, and $(R, S)$-ketamine, respectively. Additionally, treatment with $(S)$-ketamine led to proprioceptive disturbances in $100 \%$ of patients, as compared with $56 \%$ and $71 \%$ of patients receiving either $(R)$ - or $(R, S)$-ketamine, respectively (Mathisen et al., 1995). Although $43 \%$ of patients treated with $(R, S)$ ketamine reported dreams and hallucinations, neither effect was reported by patients treated with either $(S)$ - or $(R)$-ketamine (Mathisen et al., 1995).

A study conducted in healthy volunteers showed no differences in the postanesthetic effects of $(S)$ - (140 \pm $21 \mathrm{mg}),(R)-(429 \pm 37 \mathrm{mg})$, or $(R, S)$-ketamine $(275 \pm$ $25 \mathrm{mg}$ ) in their propensity to elicit floating sensations (average 67\% of individuals), diplopia (double vision; $60 \%)$, or dizziness (47\%; White et al., 1985). These effects occurred at higher plasma concentrations of $(R)$-ketamine compared with $(S)$ - and $(R, S)$-ketamine (White et al., 1985; Mathisen et al., 1995).

b. Memory and cognitive impairment. In addition to the dissociative and psychotomimetic symptoms, several studies have identified unfavorable effects of subanesthetic administration of ketamine on cognition (also see $\mathrm{Ke}$ et al., 2018). Studies have reported that ketamine decreases mental sharpness (Mathew et al., 2010), concentration (Pfenninger et al., 2002), recall and recognition (Malhotra et al., 1996), as well as explicit (episodic and semantic) and implicit (procedural) forms of memory (Harris et al., 1975; Ghoneim et al., 1985; Newcomer et al., 1999; Morgan et al., 2004; Honey et al., 2005; Driesen et al., 2013) either during or shortly after administration (for dosing details, see Table 1).

Vigilance, verbal fluency, and delayed recall are also impaired during/immediately following a 40-minute i.v. infusion of $0.5 \mathrm{mg} / \mathrm{kg}$ ketamine (resulting in plasma $\mathrm{C}_{\text {max }}$ estimated to be $\sim 100-250 \mathrm{ng} / \mathrm{ml}$ or $0.42-1.1 \mu \mathrm{M}$ ); these effects subside shortly after termination of the infusion (Krystal et al., 1994). Global cognitive function and immediate recall appear to remain intact during ketamine infusion (Krystal et al., 1994). Based on results obtained from cross-sectional studies, long-term ketamine abuse is also associated with cognitive impairments (Morgan and Curran, 2012; Zhang et al., 2018; Morgan et al., 2004). However, the nature of these studies makes it difficult to fully control for the impact of other comorbid or environmental factors (Morgan and Curran, 2012; Zhang et al., 2018).

c. Abuse. Whereas the acute psychotropic effects of ketamine may cause discomfort for some individuals (Domino et al., 1965), its dissociative properties have made it desirable for recreational use (Siegel, 1978; Stewart, 2001). However, some users may experience increased agitation or anxiety/panic attacks (Siegel, 1978; Jansen, 2000; Weiner et al., 2000; Arditti et al., 2002). Within 10 minutes following initiation of a 40 -minute i.v. infusion of a subanesthetic dose of $0.5 \mathrm{mg} / \mathrm{kg}$ ketamine (resulting in plasma $C_{\max }$ estimated to be $\sim 100-250 \mathrm{ng} / \mathrm{ml}$ or 0.42-1.1 $\mu \mathrm{M}$ ), healthy subjects reported feelings of being "high" (i.e., subjectively comparable to that of alcohol intoxication; Krystal et al., 1994). A lower ketamine dose of $0.1 \mathrm{mg} / \mathrm{kg}$ (resulting in plasma $\mathrm{C}_{\max }=\sim 25$ $50 \mathrm{ng} / \mathrm{ml}$ or $0.1-0.2 \mu \mathrm{M}$ ) induced a mild euphoria (i.e., buzzing) feeling (Krystal et al., 1994).

Although controlled studies addressing the abuse potential of ketamine are lacking, valuable information about both the acute and chronic effects of ketamine has been derived from reports of recreational use (see Corazza et al., 2013). In general, doses used for recreational ketamine intake may range between 1 and $2 \mathrm{mg} / \mathrm{kg}$ (i.v.), 50 and $150 \mathrm{mg}$ (i.m.), 100 and $500 \mathrm{mg}$ (oral), or 30 and $400 \mathrm{mg}$ (intranasal insufflation; Siegel, 1978; Dalgarno and Shewan, 1996; Jansen, 2000; Arditti et al., 2002; Wolff and Winstock, 2006; Bokor and Anderson, 2014). Although the effects of specific doses used for recreational use cannot be directly determined due to a lack of controlled studies assessing these, users report that lower doses induce mild stimulatory, dissociative, and hallucinogenic effects, whereas higher doses yield psychotomimetic symptoms and separation from reality (Stewart, 2001; Wolff and Winstock, 2006).

The most common route of recreational administration is nasal insufflation, with an onset of feeling "high" ranging between 5 and 10 minutes, and lasting between 40 and 75 minutes (Dalgarno and Shewan, 1996; Stewart, 2001; Wolff and Winstock, 2006). At peak levels of intake, users report that ketamine induces a highly dissociative experience marked by an altered state of consciousness and sensory detachment (colloquially referred to as the k-hole), which some describe as being comparable to a near-death experience (Jansen, 1989; Stewart, 2001; Wolff and Winstock, 2006; Bokor and Anderson, 2014).

At plasma concentrations ranging from 50 to $200 \mathrm{ng} / \mathrm{ml}$ (0.21-0.84 $\mu \mathrm{M}$; Bowdle et al., 1998), ketamine dose dependently enhances sensory perception (i.e., intensity of sound), emotional connectedness, feelings of unreality, and out-of-body experiences, and may be associated with visual 
hallucinations, altered perceptions of self and time, and floating sensations (Hansen et al., 1988; Bowdle et al., 1998; Jansen, 2000; Muetzelfeldt et al., 2008; Wilkins et al., 2012). Undesired effects reported by illicit users include dizziness, blurred vision, slurred speech, vomiting, palpitations, and chest pain (Siegel, 1978; Dalgarno and Shewan, 1996; Weiner et al., 2000; Muetzelfeldt et al., 2008); see section on peripheral effects below. It has been hypothesized that diminished tactile and musculoskeletal sensations caused by ketamine lead to feelings of weightlessness or detachment from oneself, which may contribute to extracorporeal sensations (Collier, 1972; White et al., 1982). Additionally, longterm use of ketamine may lead to flashbacks, attentional and other cognitive dysfunctions, and decreased sociability, but continued use is reinforced by the other psychotropic effects (Siegel, 1978; Jansen, 2000; Zhang et al., 2018). Despite its reinforcing properties, instances of ketamine dependence are relatively scarce (Bobo and Miller, 2002; Lim, 2003; Blier et al., 2012), but have been reported (Morgan and Curran, 2012). There is also evidence to suggest that repeated use of ketamine may lead to drug tolerance (Dalgarno and Shewan, 1996; Jansen and Darracot-Cankovic, 2001; Pal et al., 2002).

2. Direct and Indirect Peripheral Effects. At subanesthetic doses $(\sim 0.5 \mathrm{mg} / \mathrm{kg}$ administered i.v. over 40 minutes), ketamine can lead to vestibular perturbations, including dizziness (Wan et al., 2015) and nausea/vomiting (Ghoneim et al., 1985; Krystal et al., 1994; Morgan et al., 2004). Ketamine's actions on the sympathetic nervous system (Traber and Wilson, 1969; Traber et al., 1970) are associated with broad cardiovascular outcomes (e.g., tachycardia, hypertension, palpitations) evident in both clinical (0.5-1.0 mg/kg i.v.; Strayer and Nelson, 2008; Murrough et al., 2013b) and recreational settings (100-200 mg i.m. or s.c.; Weiner et al., 2000). Although generally considered clinically insignificant, mild respiratory depression is reported at doses ranging from 0.39 to $3.0 \mathrm{mg} / \mathrm{kg}$ (Domino et al., 1965; Idvall et al., 1979; Bourke et al., 1987). Additionally, hemodynamic effects (i.e., arterial pressure and heart rate) have not been found to vary significantly among $(S)-,(R)$-, and $(R, S)$-ketamine (White et al., 1985), although at least one study suggests that $(S)$-ketamine specifically contributes to $(R, S)$-ketamine's cardiovascular effects, such as increased blood pressure (Geisslinger et al., 1993). Overall, a recent retrospective analysis in individuals who received 684 i.v. ketamine infusions ( $0.5 \mathrm{mg} / \mathrm{kg}$ over 40 minutes) reported that alterations in blood pressure are modest, well tolerated, and clinically insignificant (Riva-Posse et al., 2018).

Ocular effects (e.g., nystagmus, diplopia, dilation) are reported in recreational contexts (Weiner et al., 2000; Stewart, 2001), as well as clinically, at subanesthetic doses of ketamine (e.g., $0.25 \mathrm{mg} / \mathrm{kg}$ i.v.; Backonja et al., 1994; Krystal et al., 1994). Some ocular effects (i.e., blurred vision) have been primarily associated with $(S)$-ketamine
(Mathisen et al., 1995). Additionally, musculoskeletal effects (e.g., myoclonus, twitching, spasms, ataxia, fasciculation) have been noted in cases of ketamine abuse (Corssen and Domino, 1966; Felser and Orban, 1982; Wolff and Winstock, 2006; Bokor and Anderson, 2014).

Prolonged recreational use of ketamine is associated with urological complications that include dysuria, increased frequency and urgency of urination, incontinence, pain, hematuria, and ulcerative cystitis (Shahani et al., 2007; Chu et al., 2008; Tsai et al., 2009; Meng et al., 2013; Skeldon and Goldenberg, 2014). It has been suggested that ketamine may have a direct detrimental impact on the interstitial cells of the bladder, since cystoscopy has shown erythema, edema, and epithelial inflammation in long-term ketamine users (Shahani et al., 2007; Chu et al., 2008). Moreover, computer tomography revealed marked bladder wall thickening, mucosal enhancement, and perivesical inflammation associated with recreational ketamine use (Mason et al., 2010). There is at least one case report of subanesthetic ketamine $(0.1 \mathrm{mg} / \mathrm{kg}$ per hour i.v. administration for 12 hours), being associated with urinary urgency and incontinence (Vickers et al., 2017).

3. Long-Term Effects. Given that ketamine's maintenance of therapeutic efficacy often requires repeated administration of the drug (e.g., Blier et al., 2012; Segmiller et al., 2013; Szymkowicz et al., 2013), it is important to consider the side effects that may be uniquely associated with chronic ketamine exposure. The effects resulting from long-term ketamine treatment are either poorly defined or scarcely reported (reviewed by Short et al., 2018). To date, repeated ketamine abuse has been most consistently associated with long-lasting memoryrelated deficits (Morgan et al., 2006; Morgan and Curran, 2012; Zhang et al., 2018). Deaths caused by ketamine overdose, in the absence of multidrug intoxication, are very rare (Gill and Stajic, 2000; Jansen, 2000), although accidental deaths caused by falls from heights, extreme hypothermia, or car accidents involving individuals using ketamine have been reported (Gill and Stajic, 2000; Jansen, 2000; Jansen and Darracot-Cankovic, 2001).

Overall, there is no report, to our knowledge, involving a lethal dose of ketamine in humans. Nevertheless, in rats, intravenous administration of $(R, S)$-ketamine and $(S)$-ketamine at the dose of $40 \mathrm{mg} / \mathrm{kg}$ induced significant lethality; whereas, all animals that received $(R)$-ketamine at the same dose survived (Marietta et al., 1977). Although these findings indicate that caution should be taken when using ketamine treatment long-term, there is evidence that repeated administration of subanesthetic doses of ketamine may have beneficial long-term effects. For instance, repeated subanesthetic ketamine has been shown to improve clinical outcomes for treatmentresistant depression (Rasmussen et al., 2013; Loo et al., 2016; Cusin et al., 2017). Repeated ketamine administration has also been associated with attenuation of the acute ketamine-induced dissociation, derealization, and dizziness over time (Grott Zanicotti et al., 2013; Singh et al., 2016b). 
Nevertheless, dissociative and psychotomimetic effects have been observed in randomized controlled studies examining the effects of repeated i.v. (Lai et al., 2014; Loo et al., 2016; Singh et al., 2016b), i.m. (Loo et al., 2016), and s.c. (Loo et al., 2016; George et al., 2017) subanesthetic ketamine exposure.

Most, if not all, side effects of ketamine are dose dependent, transient, and self-resolving (Wan et al., 2015; Kishimoto et al., 2016; Loo et al., 2016). However, to more fully assess ketamine's therapeutic utility across clinical contexts, future studies should aim to systematically assess the safety and efficacy of either acute or chronic ketamine treatment, in terms of both short- and long-term outcomes.

4. Neurotoxicity. With emerging indications requiring repeated ketamine administration (e.g., antidepressant actions), there are concerns of more profound untoward effects of treatment, including the induction of Olney lesions. First reported in 1989, Olney lesions are characterized by vacuoles occurring in the cytoplasmic compartment of selected neuronal populations, where lysis of mitochondria was reported (Olney et al., 1989, 1991). These neuronal vacuolation events occur primarily in the posterior cingulate and retrosplenial cortices following administration of $N$-methyl-D-aspartate receptor (NMDAR) antagonists (e.g., PCP, MK-801, and ketamine) in rats (Olney et al., 1989; Fix et al., 1993; Carliss et al., 2007). At low doses, vacuolation appears to reverse within 24 hours of administration, suggesting that permanent cell damage does not occur when noncompetitive (PCP, MK-801, ketamine, and dextrorphan) or competitive (CPP, CGS 19755, and CGP 37849) NMDAR antagonists are used at clinically relevant doses (Olney et al., 1989; Allen and Iversen, 1990; Hargreaves et al., 1994). However, there remains a possibility that high doses (or perhaps repeated administration at low doses) of NMDAR antagonists, such as ketamine, could lead to selective irreversible damage. For instance, preclinical studies in rats have shown that administration of a high dose of MK-801 (i.e., $5 \mathrm{mg} / \mathrm{kg}$ ) leads to necrosis in a small subset of neurons (Allen and Iversen, 1990; Auer, 1996; Kuroda et al., 2015) —an effect that was associated with an age-dependent increase in mortality rate (Auer, 1996). Additionally, studies in nonhuman primates have reported that repeated daily ketamine administration ( $1 \mathrm{mg} / \mathrm{kg}$ per day, i.v.): 1) reduced white matter integrity in fronto-thalamo-temporal connections as assessed by diffusion tensor imaging following a 3-month treatment ( $\mathrm{Li}$ et al., 2017), and 2) increased cell death in the prefrontal cortex as assessed by terminal deoxynucleotidyl transferase-mediated digoxigenin-deoxyuridine nick-end labeling staining of brain sections obtained from animals treated for 6 months (Sun et al., 2014).

Vacuolation was found to occur following administration of high (i.e., $40-60 \mathrm{mg} / \mathrm{kg}$, s.c.) but not lowto-moderate doses $(5-20 \mathrm{mg} / \mathrm{kg}$ s.c.) of ketamine in rats (Olney et al., 1989; Jevtovic-Todorovic et al., 2001). Notably, these doses are much higher than the doses required for the analgesic, anti-inflammatory, or antidepressant actions of the drug. Therefore, the relevance of Olney lesions to human repeated ketamine use is controversial and difficult to assess. One magnetic resonance imaging study reported that recreational ketamine users (total time of ketamine use: 0.5-12 years) presented with cortical atrophy in the frontal, parietal, and occipital lobes, and that measurable atrophies were associated with initiation of drug use occurring 2-4 years prior (Wang et al., 2013). In addition, another study in recreational users (total time of ketamine use: 1-10.5 years) reported a loss of frontal cortical white matter microstructure integrity that was correlated with total lifetime ketamine use (Liao et al., 2010).

Yeung et al. (2010) reported the presence of hyperphosphorylated tau (microtubule associated protein)positive cells in the prefrontal and entorhinal cortices of nonhuman primates and mice receiving daily administrations of ketamine $(1 \mathrm{mg} / \mathrm{kg}$, i.v. bolus for monkeys and $30 \mathrm{mg} / \mathrm{kg}$, i.p. injections for mice) across a period of 3-6 months. Tau hyperphosphorylation has been associated with the memory decline observed in Alzheimer's disease patients (Augustinack et al., 2002; Huang and Jiang, 2009), possibly indicating a mechanism underlying memory impairment following ketamine use (see Memory and cognitive impairment section). Moreover, chronic intermittent administration of (S)-ketamine resulted in a loss of parvalbumin immunoreactivity in the hippocampus and prefrontal cortex of mice (Yang et al., 2016), consistent with findings in animal models of psychosis and schizophrenia (Lodge et al., 2009; Gonzalez-Burgos et al., 2015). In line with the lower potency of $(R)$-ketamine to inhibit the NMDARs compared with the $(S)$-ketamine enantiomer (see section $N$-Methyl-D-Aspartate Receptors), chronic intermittent administration of $(R)$-ketamine, unlike that of $(S)$-ketamine (both administered at $10 \mathrm{mg} / \mathrm{kg}$ i.p., once per week for a total period of 8 weeks in mice), resulted in no loss of parvalbumin immunoreactivity (Yang et al., 2016). Overall, considering the expanding applications of ketamine, it will be critical to further define the long-term effects of chronic ketamine use.

Relevant doses and plasma concentrations of ketamine that result in untoward side effects in humans are listed in Table 1.

\section{Pharmacokinetics}

\section{A. Metabolism}

Ketamine undergoes extensive metabolism (Fig. 1), initially via nitrogen demethylation to norketamine, a reaction that is catalyzed primarily by the cytochrome P450 liver enzymes CYP2B6 and CYP3A4 (Kharasch and Labroo, 1992; Yanagihara et al., 2001; Hijazi and Boulieu, 2002; Portmann et al., 2010; Mossner et al., 2011; Desta et al., 2012; Rao et al., 2016). The demethylation of ketamine occurs in a stereoselective 
(R,S)-KET<smiles>CNC1(c2ccccc2Cl)CCC2CCCCC21</smiles>

(R,S)-DHNK<smiles>NC1(c2ccccc2Cl)CC=CCC1=O</smiles>

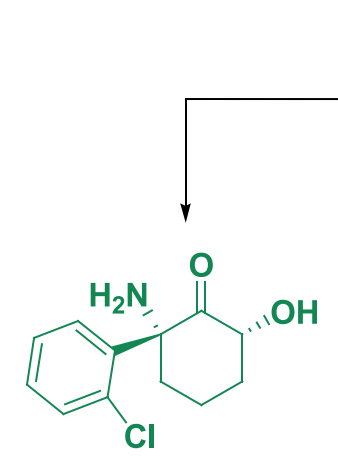

$(2 R, 6 R ; 2 S, 6 S)-H N K$
$(R, S)$-norKET<smiles>NC1(c2ccccc2Cl)CCCCC1=O</smiles>
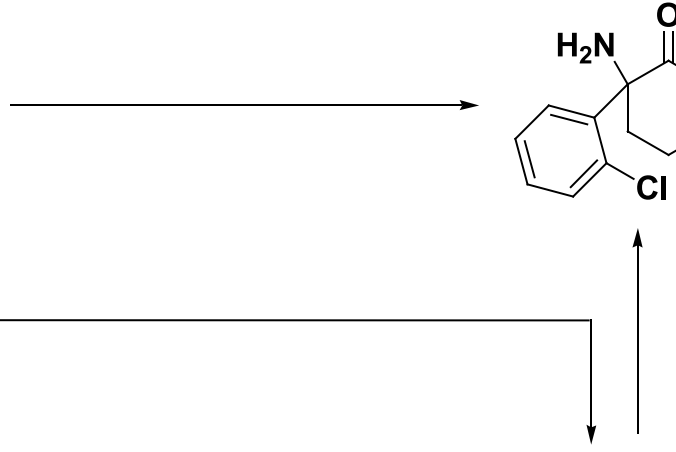<smiles>N[C@]1(c2ccccc2Cl)C[C@H](O)CCC1=O</smiles>

$(2 R, 4 R ; 2 S, 4 S)-H N K$

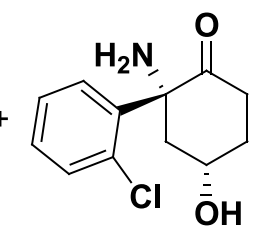

$(2 R, 4 S ; 2 S, 4 R)-\mathrm{HNK}$

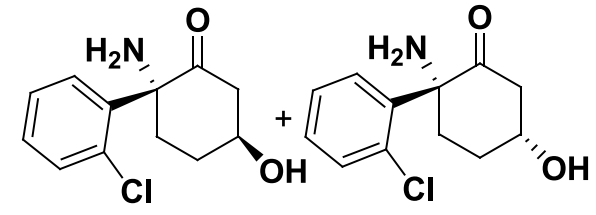

$(2 R, 5 S ; 2 S, 5 R)-\mathrm{HNK} \quad(2 R, 5 R ; 2 S, 5 S)-\mathrm{HNK}$

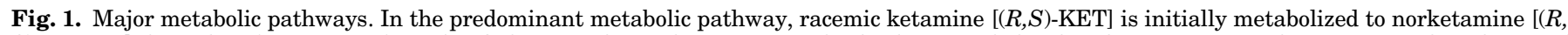

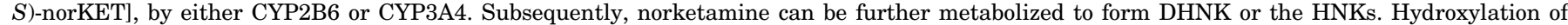

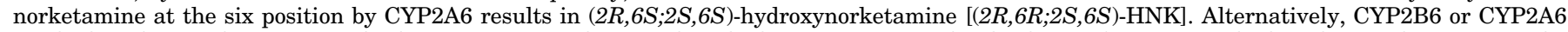

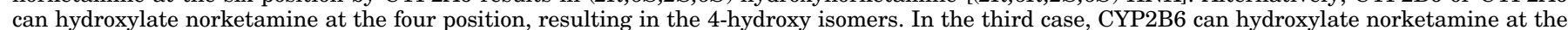

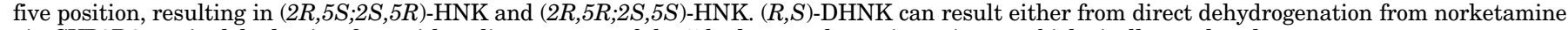
via CYP2B6 or via dehydration from either diastereomer of the 5-hydroxynorketamines via a nonbiologically catalyzed process.

manner, as CYP3A4 demethylates the $(S)$-ketamine enantiomer more rapidly than the $(R)$-ketamine enantiomer, whereas CYP2B6 demethylates both enantiomers of ketamine with near equal efficiency (Portmann et al., 2010). The individual variability in the metabolism of ketamine (Hijazi and Boulieu, 2002; Cheng et al., 2007; Desta et al., 2012) has been attributed, in part, to differences in the expression of $\mathrm{P} 450$ enzymes (Shimada et al., 1994; Hijazi and Boulieu, 2002).

Following demethylation of ketamine to norketamine, norketamine is further metabolized to the hydroxynorketamines (HNKs) and dehydronorketamine (DHNK) (Fig. 1). Early studies noted that the HNKs are formed through the hydroxylation of the cyclohexyl ring of norketamine at various locations (Adams et al., 1981). Several of these HNK metabolites have been detected in humans following ketamine infusion, with $(2 R, 6 R$; $2 S, 6 S)$-HNK and $(2 S, 6 R ; 2 R, 6 S)$-HNK being the predominant circulating HNKs in plasma (Moaddel et al., 2010; Zarate et al., 2012a). Metabolism to $(2 R, 6 R$; $2 S, 6 S)-\mathrm{HNK}$ is primarily carried out by CYP2A6 and CYP2B6 (Moaddel et al., 2010; Desta et al., 2012). These enzymes are also responsible for the formation of the $(2 S, 4 S ; 2 R, 4 R)$ - and $(2 S, 5 S ; 2 R, 5 R)$-HNKs. CYP3A4 and CYP3A5 are the principal enzymes identified to catalyze the conversion of norketamine to $(2 S, 4 R ; 2 R, 4 S)-\mathrm{HNK}$, whereas CYP2B6 is predominantly responsible for the catalysis of the conversion of norketamine to $(2 S, 5 R$; $2 R, 5 S$ )-HNK (Desta et al., 2012). The other secondary metabolite is DHNK (Chang and Glazko, 1972; Adams et al., 1981). DHNK is directly formed from norketamine primarily via the actions of the CYP2B6 enzyme, or from 5 -HNK via a nonenzymatic dehydration event (Adams et al., 1981; Bolze and Boulieu, 1998; Turfus et al., 2009; Portmann et al., 2010; Desta et al., 2012).

In addition to the major metabolic pathways of ketamine, there are several other pathways that have also been studied (Fig. 2). One of these pathways is the direct hydroxylation of ketamine to 6-hydroxyketamine (HK) (Woolf and Adams, 1987; Desta et al., 2012). Metabolism of ketamine to $(2 R, 6 R ; 2 S, 6 S)-\mathrm{HK}$ is primarily catalyzed by CYP2A6, whereas $(2 S, 6 R ; 2 R, 6 S)$-HK production is catalyzed by the CYP3A4 and CYP3A5 enzymes (Desta et al., 2012). The formation of $(2 R, 6 R ; 2 S, 6 S)-\mathrm{HK}$ is associated with greater hydroxylation of $(S)$-ketamine relative to $(R)$-ketamine, suggesting this reaction is enantioselective (Desta et al., 2012). The (2R,6R;2S,6S)-HK metabolite is readily demethylated via CYP2B6 to the corresponding HNK (Desta et al., 2012). However, analogous demethylation from the $(2 S, 6 R ; 2 R, 6 S)-\mathrm{HK}$ metabolite is reported to occur very slowly, with a modest contribution from CYP3A5. In addition to 6-HKs, evidence for the production of the 4-HK metabolite has been reported (Adams et al., 1981; Moaddel et al., 2010; Desta et al., 2012; Zarate et al., 2012a). Whereas hydroxylation of the phenyl ring was initially ruled out as being part of the metabolism of ketamine, more recent studies have provided evidence for the formation of such hydroxyphenyl ketamine metabolites via the actions of the CYP2C9 [primarily for the $(R)$-ketamine enantiomer] and flavin-containing mono-oxygenase enzymes [primarily for the $(S)$-ketamine enantiomer; Desta et al., 2012]. 
<smiles>CNC1(c2ccccc2Cl)CCCCC1=O</smiles><smiles>NC1(c2ccccc2Cl)CCCC(=O)C1</smiles><smiles>NC1(c2ccccc2Cl)CCCCC1=O</smiles>

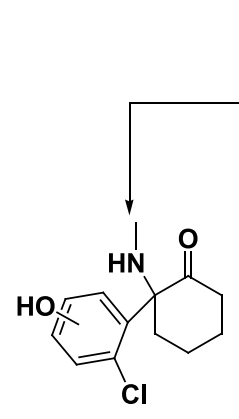

Hydroxyphenyl

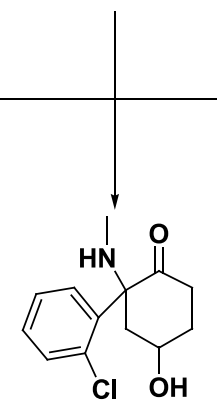

4-HK

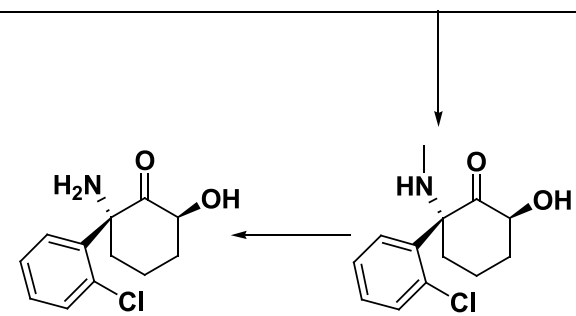

$(2 R, 6 S ; 2 S, 6 R)-\mathrm{HNK}$

(2R,6S;2S,6R)-HK
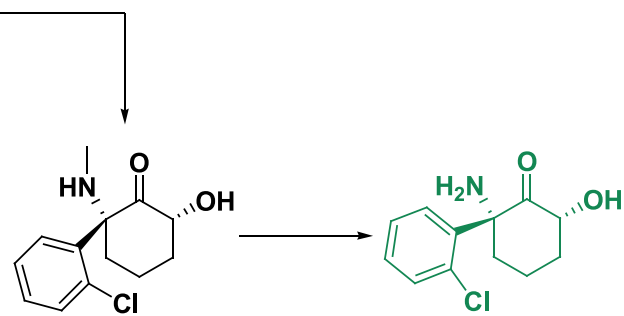

$(2 R, 6 R ; 2 S, 6 S)-\mathrm{HK}$

$(2 R, 6 R ; 2 S, 6 S)-H N K$

Fig. 2. Minor metabolic pathways. Although the majority of ketamine is metabolized via the major metabolic pathways (Fig. 1), there are several minor metabolic pathways, which provide unique, albeit low abundance, ketamine metabolites. The aryl ring of ketamine can be directly hydroxylated by flavin-containing mono-oxygenase enzymes or CYP2C9 to provide hydroxyphenyl-ketamine (hydroxyphenyl-KET). 4-Hydroxyketamine has also been observed; however, the metabolic enzymes responsible for this are currently unknown. CYP3A5 can directly hydroxylate ketamine at the six position to provide $(2 R, 6 S ; 2 S, 6 R)$-HK. Demethylation of $(2 R, 6 S ; 2 S, 6 R)$-HK with CYP3A5 provides $(2 R, 6 S ; 2 S, 6 R)$-HNK. CYP2A6 can also directly hydroxylate ketamine to provide $(2 R, 6 R ; 2 S, 6 S)$-HK, which is then transformed to $(2 R, 6 R ; 2 S, 6 S)$-HNK. Finally, norketamine can be hydroxylated via an unknown enzyme directly on the aryl rich to provide hydroxyphenyl-norketamine (hydroxyphenyl-norKET).

Lastly, phenolic isomers of HNKs have also been observed, potentially resulting from the hydroxylation of norketamine (Turfus et al., 2009).

A population pharmacokinetic model was constructed for ketamine and its metabolites in patients suffering from treatment-resistant bipolar depression in a study that identified norketamine, DHNK, and (2R,6R;2S,6S)$\mathrm{HNK}$ as the major circulating metabolites in plasma following a single 40-minute i.v. infusion of ketamine $(0.5 \mathrm{mg} / \mathrm{kg}$ ) (Zhao et al., 2012). These were also the major metabolites identified in plasma of patients suffering from unipolar or bipolar depression (Zarate et al., 2012a) or CRPS (Moaddel et al., 2010) and treated with ketamine. Specifically, norketamine, DHNK, and $(2 R, 6 R ; 2 S, 6 S)$ $\mathrm{HNK}$ were detected in the plasma of patients suffering from treatment-resistant unipolar and bipolar depression as early as 40 minutes after the end of i.v. ketamine administration $(0.5 \mathrm{mg} / \mathrm{kg}$ delivered during a single 40-minute infusion; Zarate et al., 2012a; Zhao et al., 2012). The average time for metabolites to reach peak plasma concentration was estimated to be approximately 1.33 hours for both $(R)$ - and $(S)$-norketamine and 3.83 hours for $(R)$-DHNK, $(S)$-DHNK, and $(2 R, 6 R$; $2 S, 6 S$ )-HNK (Zhao et al., 2012). In plasma samples from these patients, the ratios of $(S)$ - to $(R)$-ketamine, $(S)$ - to $(R)$-norketamine, and $(S)$ - to $(R)$-DHNK were $0.84,1.0$, and 0.67 , respectively, during a 40 - to 230-minute postinfusion period (Zhao et al., 2012). Similar to these findings, i.v. administration of ketamine $(2 \mathrm{mg} / \mathrm{kg})$ in surgical patients resulted in a plasma ratio of $(S)$ - to $(R)$ ketamine of 0.91 (Geisslinger et al., 1993). Additionally, CRPS patients receiving continuous i.v. ketamine infusion at a dose of $40 \mathrm{mg} / \mathrm{h}$ over a total period of 5 days had plasma ratios of $(S)$ - to $(R)$-ketamine, $(S)$ - to $(R)$-norketamine, and $(S)$ - to $(R)$-DHNK of $0.77,0.71$, and 0.71 , respectively (Moaddel et al., 2010).

Following a 40-minute i.v. ketamine infusion at $0.5 \mathrm{mg} / \mathrm{kg}$ in patients diagnosed with treatment-resistant major depressive disorder, peak plasma concentrations were $204.13 \pm 101.46 \mathrm{ng} / \mathrm{ml}$ or $0.86 \pm 0.43 \mu \mathrm{M}$ for ketamine (at 40 minutes), $73.54 \pm 31.86 \mathrm{ng} / \mathrm{ml}$ or $0.33 \pm$ $0.14 \mu \mathrm{M}$ for norketamine (at 80 minutes), $13.27 \pm$ $6.92 \mathrm{ng} / \mathrm{ml}$ or $0.06 \pm 0.03 \mu \mathrm{M}$ for DHNK (at 110 minutes), and $23.19 \pm 11.88 \mathrm{ng} / \mathrm{ml}$ or $0.097 \pm 0.05 \mu \mathrm{M}$ for $(2 R, 6 R$; $2 S, 6 S$ )-HNK (at 230 minutes) (Zarate et al., 2012a); see Table 2. In patients with treatment-resistant bipolar depression, peak plasma concentrations were $177.23 \pm$ $53.8 \mathrm{ng} / \mathrm{ml}$ or $0.75 \pm 0.23 \mu \mathrm{M}$ for ketamine (at 40 minutes), $69.96 \pm 19.98 \mathrm{ng} / \mathrm{ml}$ or $0.31 \pm 0.09 \mu \mathrm{M}$ for norketamine (at 80 minutes), $50.5 \pm 27.44 \mathrm{ng} / \mathrm{ml}$ or $0.23 \pm 0.12 \mu \mathrm{M}$ for DHNK (at 110 minutes), and $37.59 \pm 14.23$ or $0.16 \pm$ $0.06 \mu \mathrm{M}$ for $(2 R, 6 R ; 2 S, 6 S)$-HNK (Zarate et al., 2012a; Table 2). In a patient with CRPS receiving chronic ketamine treatment (infusion beginning at $10 \mathrm{mg} / \mathrm{h}$, titrated to $40 \mathrm{mg} / \mathrm{h}$, and lasting 5 consecutive days), significant plasma levels of several HNK metabolites were detected, with $(2 R, 6 R ; 2 S, 6 S)$ - and $(2 R, 6 R ; 2 S, 6 S)$ HNKs being the major metabolites present in samples obtained on day 3 (Moaddel et al., 2010).

In a study conducted by Cohen et al. (1973), brain concentrations of ketamine metabolites were measured following tail vein administration of ketamine $(20 \mathrm{mg} / \mathrm{kg})$ in rats. These authors showed that both ketamine and norketamine rapidly accumulated in the brain with peak 
concentrations achieved within 1 minute of administration (Cohen et al., 1973). Subsequently, it was demonstrated that $(2 R, 6 R ; 2 S, 6 S)$-HNK also accumulates in brain tissue shortly after dosing (Leung and Baillie, 1986; Paul et al., 2014; Moaddel et al., 2015b). Intravenous tail vein injection (2-minute infusion) of $20 \mathrm{mg} / \mathrm{kg}(S)$ - or $(R)$-ketamine to rats resulted in higher brain levels of $(2 S, 6 S)$-HNK relative to $(2 R, 6 R)$-HNK, respectively, with maximal concentrations of $769 \pm 133 \mathrm{ng} / \mathrm{g}$ or $3.21 \pm$ $0.55 \mu \mathrm{mol} / \mathrm{kg}$ at 20 minutes for $(2 S, 6 S)-\mathrm{HNK}$ and $274 \pm$ $47 \mathrm{ng} / \mathrm{g}$ or $1.14 \pm 0.20 \mu \mathrm{mol} / \mathrm{kg}$ at 10 minutes for $(2 R, 6 R)$ HNK (Moaddel et al., 2015b; Table 2). It was hypothesized that the difference was due to a passive uptake process of these metabolites into the brain (Moaddel et al., 2015b). A 1:1 ratio for the plasma:brain levels of the corresponding $(2 R, 6 R ; 2 S, 6 S)-\mathrm{HNK}$ was observed, indicating that blood-brain barrier penetration or the central nervous system transport process was not mediated by an enantioselective process (Leung and Baillie, 1986; Moaddel et al., 2015b). Importantly, no in situ metabolism was observed when ketamine was incubated with rat brain microsomes (S9 fraction) (Moaddel et al., 2015b). Likewise, ketamine metabolites were below detectable levels in the brain of mice following in vivo intracerebroventricular administration of ketamine (P.Z., R.M., J.N.H., T.D.G., unpublished data), a finding that suggests that local ketamine metabolism does not occur in the brain.

In mice, norketamine, DHNK, and $(2 R, 6 R ; 2 S, 6 S)-\mathrm{HNK}$ metabolites were detected in plasma within 10 minutes of i.p. administration of $10 \mathrm{mg} / \mathrm{kg}$ ketamine (Can et al., 2016; Zanos et al., 2016). The maximum plasma concentrations were $561.89 \pm 86.09 \mathrm{ng} / \mathrm{ml}$ or $2.36 \pm 0.18 \mu \mathrm{M}$ at 10 minutes for ketamine, $1098.89 \pm 216.89 \mathrm{ng} / \mathrm{ml}$ or $4.91 \pm 0.97 \mu \mathrm{M}$ at 10 minutes for norketamine, $83.92 \pm$ $53.63 \mathrm{ng} / \mathrm{ml}$ or $0.38 \pm 0.24 \mu \mathrm{M}$ at 30 minutes for DHNK, and $674.59 \pm 278.23 \mathrm{ng} / \mathrm{ml}$ or $2.81 \pm 1.16 \mu \mathrm{M}$ at 10 minutes for $(2 R, 6 R ; 2 S, 6 S)$-HNK (Zanos et al., 2016), as summarized in Table 2 . In the brain, ketamine $(1162.34 \pm 202.05 \mathrm{ng} / \mathrm{g}$ or $4.89 \pm 0.85 \mu \mathrm{mol} / \mathrm{kg}$ tissue), norketamine $(450.94 \pm 199.7 \mathrm{ng} / \mathrm{g}$ or $2.02 \pm 0.89 \mu \mathrm{mol} / \mathrm{kg}$ tissue), and $(2 R, 6 R ; 2 S, 6 S)-H N K(498.35 \pm 50.99 \mathrm{ng} / \mathrm{g}$ or $2.08 \pm 0.21 \mu \mathrm{mol} / \mathrm{kg}$ tissue) were detected within 10 minutes of ketamine administration (Zanos et al., 2016). The maximum brain concentration of ketamine was $51.66 \%$ higher than the corresponding plasma concentration, whereas the brain tissue concentrations of norketamine and $(2 R, 6 R ; 2 S, 6 S)$-HNK were $58.96 \%$ and $26.13 \%$ lower than the corresponding maximum plasma concentrations, respectively (Zanos et al., 2016). Levels of DHNK in brain tissue were below the limits of quantification, consistent with the findings that DHNK partitions into red blood cells (Moaddel et al., 2016) and has poor penetration of the blood-brain barrier (Can et al., 2016).

\section{B. Absorption}

Ketamine is administered to humans via multiple routes, including i.v., i.m., oral, intranasal, epidural, and intrarectal (Malinovsky et al., 1996; Andrade, 2017b). The most typical route of administration is via i.v. infusion, which rapidly attains maximum plasma concentrations (e.g., Clements et al., 1982; Weber et al., 2004). Intramuscular administration, which is used in emergency cases of uncooperative patients, neonates, and children, has high bioavailability of $93 \%$, with peak plasma concentrations achieved within 5-30 minutes of administration (e.g., Clements et al., 1982); however, a population pharmacokinetic analysis reported a much lower bioavailability following i.m. administration of ketamine in children (41\%; Hornik et al., 2013). In contrast, oral bioavailability of ketamine is limited to $16 \%-29 \%$, with peak concentration levels of the drug occurring within 20-120 minutes (Grant et al., 1981; Clements et al., 1982; Sekerci et al., 1996; Chong et al., 2009; Rolan et al., 2014; Karch and Drummer, 2015), due to extensive first-pass hepatic metabolism (e.g., Kharasch and Labroo, 1992; Yanagihara et al., 2003). Oral bioavailability of $(S)$-ketamine was calculated to be $8 \%-11 \%$ (Peltoniemi et al., 2012; Fanta et al., 2015), consistent with the greater first-pass metabolism of $(S)$-ketamine relative to $(R, S)$-ketamine. Intranasal and intrarectal ketamine bioavailability is $45 \%-50 \%$ and 25\%-30\%, respectively (Malinovsky et al., 1996; Yanagihara et al., 2003). Intranasal administration is considered an attractive alternative to the i.v. administration of ketamine because it is less invasive, results in rapid systemic absorption, and is not subject to firstpass hepatic metabolism (Malinovsky et al., 1996).

Following oral administration of $(2 S, 6 S)$-HNK in rats $(20 \mathrm{mg} / \mathrm{kg})$, maximum plasma concentrations were reached at $0.4 \pm 0.1$ hour. Oral bioavailability of $(2 S, 6 S)$-HNK was estimated to be $46.3 \%$ in rats (Moaddel et al., 2015b). In mice, the oral bioavailability of $(2 R, 6 R)$-HNK is estimated to be approximately $50 \%$ at the dose of $50 \mathrm{mg} / \mathrm{kg}$ (P.Z., R.M., J.N.H., T.D.G., unpublished data). The oral bioavailability of other ketamine metabolites remains to be determined.

\section{Distribution}

Ketamine is rapidly distributed into highly perfused tissues, including the brain, and has a plasma protein binding between $10 \%$ and 50\% (Wieber et al., 1975; Dayton et al., 1983; Sinner and Graf, 2008; Peltoniemi et al., 2012, 2016; Karch and Drummer, 2015), resulting in a large steady-state volume of distribution $\left(\mathrm{V}_{\mathrm{d}}=3-5 \mathrm{l} / \mathrm{kg}\right.$; Karch and Drummer, 2015). A single i.v. bolus administration of an anesthetic dose of racemic ketamine in humans $(2 \mathrm{mg} / \mathrm{kg})$ leads to equal plasma concentrations of $(S)$-ketamine and $(R)$-ketamine 1 minute postadministration $\left(\mathrm{C}_{\max }=\sim 1800 \mathrm{ng} / \mathrm{ml}\right.$ or $7.6 \mu \mathrm{M}$-estimated from Geisslinger et al., 1993). However, i.v. (bolus) administration of $1 \mathrm{mg} / \mathrm{kg}(S)$-ketamine resulted in a higher plasma concentration of the drug 1 minute postinfusion $\left(\mathrm{C}_{\max }=\sim 2600 \mathrm{ng} / \mathrm{ml}: 11 \mu \mathrm{M}\right.$ - estimated from Geisslinger et al., 1993). These results are particularly 


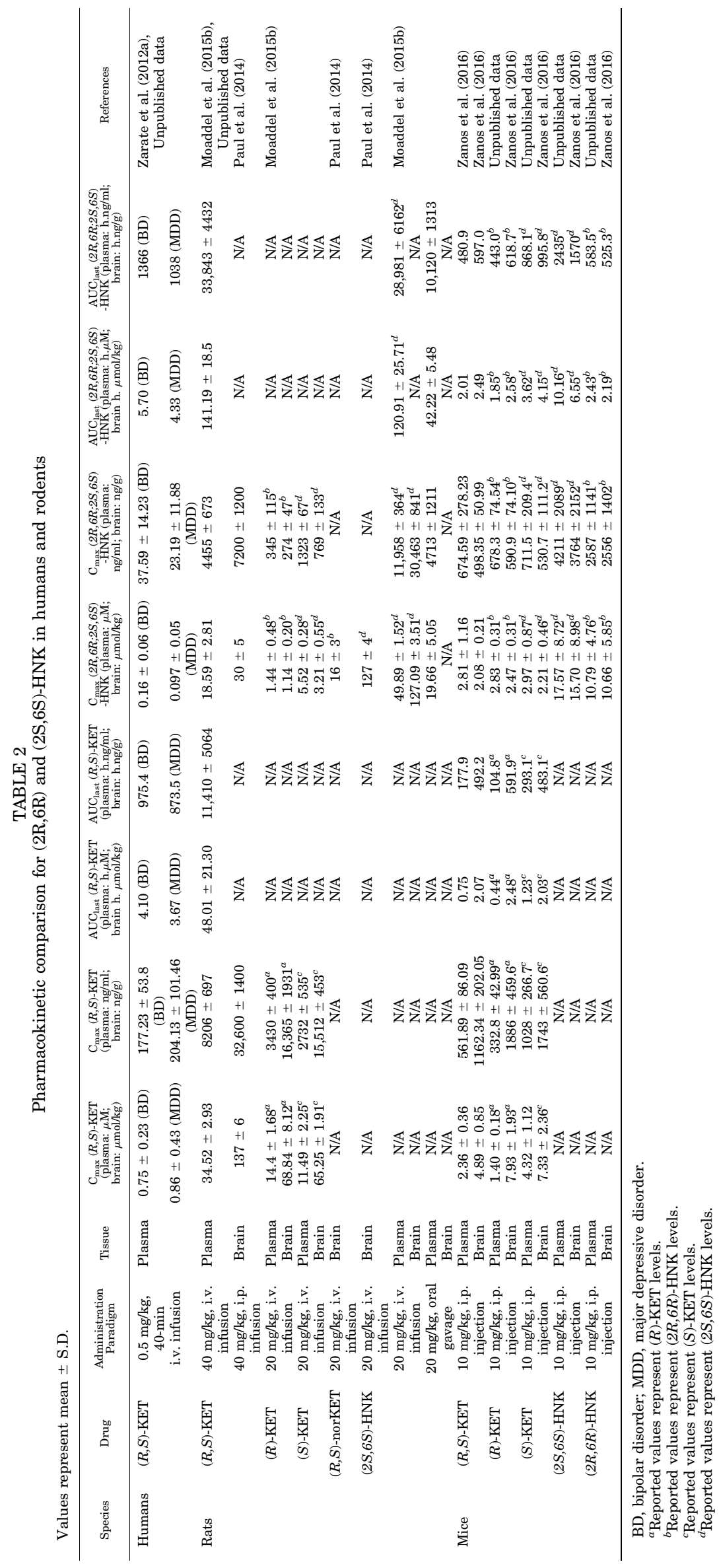


important when comparing the outcomes of $(S)$-ketamine with those of the racemic ketamine or $(R)$-ketamine, because lower doses of $(S)$-ketamine are required to produce similar or greater ketamine concentrations in the plasma (e.g., White et al., 1985; Mathisen et al., 1995). Notably, there is no interconversion between (S)and $(R)$-ketamine, because administration of $(S)$-ketamine does not result in the formation of $(R)$-ketamine in vivo, and vice versa (Geisslinger et al., 1993; Ihmsen et al., 2001). Plasma of patients suffering from treatment-resistant bipolar depression, who were treated with a 40 -minute i.v. infusion of $0.5 \mathrm{mg} / \mathrm{kg}(R, S)$-ketamine, had a ratio of $(S)$ - to $(R)$-ketamine of 0.84 (Zhao et al., 2012), with peak ketamine concentrations of $177.23 \pm 53.8 \mathrm{ng} / \mathrm{ml}$ or $0.75 \pm 0.23 \mu \mathrm{M}$ (Zarate et al., 2012a).

In mice, administration of subanesthetic doses of either $(S)$ - or $(R)$-ketamine $(10 \mathrm{mg} / \mathrm{kg}$, i.p.) resulted in similar brain levels of both drugs [area under the curve $(\mathrm{AUC})_{\text {last }}=483.1$ hours.ng $/ \mathrm{ml}$ or 2.03 hours. $\mu \mathrm{mol} / \mathrm{kg}$ versus 591.9 hours.ng/ml or 2.48 hours. $\mu \mathrm{mol} / \mathrm{kg}$, respectively], with peak levels being $\mathrm{C}_{\max }=1743 \pm$ $560.6 \mathrm{ng} / \mathrm{g}$ or $7.33 \pm 2.36 \mu \mathrm{mol} / \mathrm{kg}$ for $(S)$-ketamine and $1886 \pm 459.6 \mathrm{ng} / \mathrm{ml}$ or $7.93 \pm 1.93$ for $(R)$-ketamine at 10 minutes postinjection (Zanos et al., 2016). Similarly, there were no differences in $(S)$-ketamine $\left(\mathrm{C}_{\max }=\right.$ $2732 \pm 535 \mathrm{ng} / \mathrm{ml}$ or $11.49 \pm 2.25 \mu \mathrm{M})$ and $(R)$-ketamine $\left(\mathrm{C}_{\max }=3430 \pm 400 \mathrm{ng} / \mathrm{ml}\right.$ or $\left.14.4 \pm 1.68 \mu \mathrm{M}\right)$ levels in the plasma of rats 10 minutes following an i.v. administration of $20 \mathrm{mg} / \mathrm{kg}$ of each of these enantiomers (Moaddel et al., 2015b).

Direct i.p. administration of $(2 R, 6 R)$-HNK and $(2 S, 6 S)$ $\mathrm{HNK}$ in mice results in a 1:1 ratio between circulating plasma and brain tissue concentrations (Table 2), with higher total levels $\left(\mathrm{AUC}_{\text {last }}\right)$ of $(2 S, 6 S)$-HNK observed in plasma and brain tissue compared with $(2 R, 6 R)$-HNK (brain: 7.55 versus 3.05 h. $\mu \mathrm{mol} / \mathrm{kg}$; plasma: 11.60 versus 3.22 h. $\mu \mathrm{M}$; Zanos et al., 2016; Table 2). Following i.v. administration of $(2 S, 6 S)-\mathrm{HNK}$ in rats $(20 \mathrm{mg} / \mathrm{kg})$, total drug exposure was calculated as $\mathrm{AUC}_{\text {last }}=28,981 \pm$ $6162 \mathrm{~h} . \mathrm{ng} / \mathrm{ml}$ or $120.91 \pm 25.71 \mathrm{~h} . \mu \mathrm{M}$, with a volume of distribution $V_{\mathrm{d}}=7.35 \pm 0.74 \mathrm{l} / \mathrm{kg}$ (Moaddel et al., $2015 b)$. Following oral administration of (2S, $6 S)$-HNK to rats $(20 \mathrm{mg} / \mathrm{kg})$, total drug exposure was $\mathrm{AUC}_{\text {last }}=$ $10,120 \pm 1313 \mathrm{~h} . \mathrm{ng} / \mathrm{ml}$ or $42.22 \pm 5.48 \mathrm{~h} . \mu \mathrm{M}$ (Moaddel et al., 2015b).

\section{Elimination}

Although plasma levels of ketamine are below detectable limits within 1 day following an i.v. antidepressant dose of ketamine $(0.5 \mathrm{mg} / \mathrm{kg}$ administered over a 40-minute infusion), circulating levels of DHNK and $(2 R, 6 R ; 2 S, 6 S)$-HNK were observed for up to 3 days after ketamine infusion in patients diagnosed with bipolar depression (Zhao et al., 2012) or treatment-resistant major depression (Zarate et al., 2012a). Norketamine and ketamine were detectable for up to 14 and 11 days, respectively, in the urine of children who received anesthetic doses of ketamine, with reported concentrations of $0.1-1442 \mathrm{ng} / \mathrm{ml}$ (or $0.0004-0.031 \mu \mathrm{M}$ ) for norketamine and 2-1204 ng/ml (or 0.008-5.06 $\mu \mathrm{M}$ ) for ketamine (Adamowicz and Kala, 2005).

In adult humans, ketamine has a high rate of clearance and a short elimination half-life (2-4 hours; Clements et al., 1982; White et al., 1985; Domino, 2010). White et al. (1985) also demonstrated a short elimination half-life (155-158 minutes) for both $(S)$-ketamine and $(R)$-ketamine. Elimination of ketamine is primarily performed by the kidneys, with low levels excreted as ketamine (2\%), norketamine (2\%), and DHNK (16\%) (Haas and Harper, 1992; Lin and Lua, 2004; Adamowicz and Kala, 2005; Karch and Drummer, 2015; Dinis-Oliveira, $2017)$. The majority of the drug $(\sim 80 \%)$ is excreted as the glucuronic acid-labile conjugates of $\mathrm{HK}$ and HNK (Dinis-Oliveira, 2017), which are eliminated in urine and bile (Chang and Glazko, 1974).

In adult humans, terminal plasma half-life and the clearance rates of ketamine do not significantly differ between i.v. (half-life = 186 minutes; total body clearance $=19.1 \mathrm{ml} / \mathrm{min}$ per kilogram) and intramuscular (half-life $=155$ minute; total body clearance $=23.2 \mathrm{ml} / \mathrm{min}$ per kilogram) routes of administration (Clements et al., 1982). However, there is evidence that repeated administration of ketamine prolongs its elimination time. For example, Adamowicz and Kala (2005) reported that, among three instances of single i.v. infusions of ketamine during a 2-year period (doses ranged from 0.75 to $1.59 \mathrm{mg} / \mathrm{kg}$ ), the elimination of ketamine was slowed from 2 days following the first infusion to 5 days after the second, and 11 days following the third. Elimination of norketamine remained constant (i.e., 5 days after each infusion; Adamowicz and Kala, 2005).

When compared with adults, ketamine is eliminated approximately twice as fast in children (Haas and Harper, 1992). This is in accordance with evidence supporting a longer duration of anesthesia in adults relative to children following i.m. administration of $6 \mathrm{mg} / \mathrm{kg}$ ketamine (Grant et al., 1981, 1983; Akin et al., 2005). Moreover, a negative correlation between age and ketamine dose per body weight required for anesthesia was reported in children (Lockhart and Nelson, 1974). These differences might be due to differences in the enzymatic metabolism of ketamine in children, as compared with adults (Edginton et al., 2006).

In humans, $(S)$-ketamine has a slightly longer elimination half-life than racemic ketamine $[\sim 5$ hours for (S)-ketamine versus 2-4 hours for racemic ketamine; Hagelberg et al., 2010; Peltoniemi et al., 2012], and its systemic clearance is faster when administered alone than when administered in the racemic mixture [26.3 \pm $3.5 \mathrm{ml} / \mathrm{kg}$ per minute for $(S)$-ketamine versus $14.8 \pm$ $1.7 \mathrm{ml} / \mathrm{kg}$ per minute when administered as the racemic ketamine; Ihmsen et al., 2001]. This may suggest an inhibition of $(S)$-ketamine's clearance by the $(R)$-ketamine enantiomer when the racemic mixture is administered 
(Kharasch and Labroo, 1992). Such inhibition could contribute to the prolonged awakening time in patients receiving racemic ketamine relative to those receiving $(S)$-ketamine (White et al., 1985). We note that systemic clearance of $(R)$-ketamine following racemic ketamine administration is $13.8 \pm 1.3 \mathrm{ml} / \mathrm{kg}$ per minute, which is similar to the $(S)$-ketamine enantiomer $(14.8 \pm 1.7 \mathrm{ml} / \mathrm{kg}$ per minute; Ihmsen et al., 2001).

Following i.v. administration of $(2 S, 6 S)$-HNK in rats $(20 \mathrm{mg} / \mathrm{kg})$, the clearance rate was calculated to be $704 \pm 139 \mathrm{ml} / \mathrm{kg}$ per hour, with an elimination halflife of $8.0 \pm 4.0$ hours. Oral administration of this metabolite resulted in an elimination half-life of $3.8 \pm$ 0.6 hours (Moaddel et al., 2015b).

Overall, it is important to note that there are important species differences in regard to half-life values, AUCs, $\mathrm{C}_{\text {max }}$, and clearance rates of ketamine and its metabolites (see Table 2; also see Zarate et al., 2012a; Zanos et al., 2017c). This should be taken into consideration when comparing the behavioral actions of specific dose regimens for ketamine and its metabolites in mice, rats, and humans. Nevertheless, the brain levels of ketamine and its metabolites following administration of ketamine in humans are not known, and, therefore, direct comparisons are not straightforward.

\section{Pharmacodynamics of Ketamine and Its Metabolites}

As aforementioned, ketamine is a NMDAR antagonist, and ketamine's well-characterized analgesic and anesthetic effects are primarily attributed to NMDAR inhibition (Franks and Lieb, 1994). However, ketamine's pharmacological targets are not limited to NMDARs. It has been reported that ketamine interacts with several other receptors and ion channels, including dopamine, serotonin, sigma, opioid, and cholinergic receptors, as well as hyperpolarization-activated cyclic nucleotidegated (HCN) channels. Ketamine typically has a lower affinity (higher inhibitory constant- $\mathrm{K}_{\mathrm{i}}$-values) for these receptors and channels compared with NMDARs, and independent laboratories have not validated many of the reported findings.

Early pharmacodynamic studies of $(R, S)$-ketamine were conducted in rats and examined the anesthetic effects of the parent compound and its two principal metabolites, $(R, S)$-norketamine and $(2 R, 6 R ; 2 S, 6 S)$ HNK (Leung and Baillie, 1986). The results demonstrated that a $40 \mathrm{mg} / \mathrm{kg}$ i.v. bolus administration of $(R, S)$-ketamine and $(R, S)$-norketamine produced anesthetic actions and increased spontaneous locomotor activity during the postanesthetic recovery phase, whereas $(2 R, 6 R ; 2 S, 6 S)$-HNK (same dose) had no anesthetic or hyperlocomotor effects. As a result, $(2 R, 6 R ; 2 S, 6 S)$-HNK was described as an inactive metabolite, and the majority of the pharmacodynamic assessments were carried out with only $(R, S)$ ketamine and $(R, S)$-norketamine. However, it has been recently demonstrated that ketamine's HNK metabolites are biologically active (Moaddel et al., 2013; Singh et al., 2013, 2015, 2016c; Paul et al., 2014; Zanos et al., 2016; Cavalleri et al., 2017; Yao et al., 2017; Wray et al., 2018). The $(2 S, 6 S)$ - and $(2 R, 6 R)$-HNK metabolites have been shown to exert antidepressant-relevant behavioral responses in rodents (Zanos et al., 2016; Pham et al., 2017a, but see Shirayama and Hashimoto, 2018, as well as Yang et al., 2017). Consistent with the more potent antidepressant actions of $(R)$-ketamine compared with the $(S)$-ketamine enantiomer, $(2 R, 6 R)$-HNK was shown to be a more potent antidepressant than $(2 S, 6 S)$ HNK in several animal tests (Zanos et al., 2016).

\section{A. N-Methyl-D-Aspartate Receptors}

Historically, the primary recognized receptor target of ketamine is the NMDAR, in which ketamine acts as a noncompetitive open-channel blocker (Lodge et al., 1982; Anis et al., 1983; MacDonald et al., 1987). NMDARs are glutamatergic ion channels made of different combinations of four subunits encoded by one of seven genes: GluN1, GluN2A-D, and GluN3A-B (Vyklicky et al., 2014). NMDARs are highly permeable to calcium ions, which can trigger the activation of a number of intracellular pathways in neurons and glial cells. At resting state, NMDAR channels are tonically blocked by magnesium $\left(\mathrm{Mg}^{2+}\right)$. Efficient receptor activation requires the following: 1) membrane depolarization, which displaces the $\mathrm{Mg}^{2+}$ block, and 2) binding of both glutamate and the coactivator glycine and/or D-serine (Paoletti et al., 2013).

Ketamine was initially characterized as a NMDAR antagonist by David Lodge and colleagues (Lodge et al., 1982; Anis et al., 1983), a finding that was subsequently confirmed by other investigators (Harrison and Simmonds, 1985; Thomson et al., 1985). Ketamine binds to the allosteric phencyclidine (PCP) site that is located within the channel pore of the NMDAR, and thus it blocks the receptor noncompetitively (Kohrs and Durieux, 1998; Mion and Villevieille, 2013). Ketamine has a relatively high $(\sim 86 \%)$ trapping capability (binding within the ion channel pore following closure of the channel) to block NMDARs, via binding to the same site as PCP (>98\% trapping) and MK-801 (100\% trapping; Huettner and Bean, 1988; Lerma et al., 1991; MacDonald et al., 1991; Jahr, 1992; Orser et al., 1997). The binding affinity of ketamine to the PCP binding site has been reported to be between 0.18 and $3.1 \mu \mathrm{M}$ in the presence of $\mathrm{Mg}^{2+}$ (Table 3; Wong et al., 1986, 1988; MacDonald et al., 1987; Kornhuber et al., 1989; Reynolds and Miller, 1989; Sharif et al., 1991; Bresink et al., 1995; Lynch et al., 1995; Parsons et al., 1995; Kapur and Seeman, 2001, 2002; Sun and Wessinger, 2004; Seeman et al., 2005; Gilling et al., 2009; Moaddel et al., 2013; Bonifazi et al., 2015; Wallach et al., 2016; Kang et al., 2017; Morris et al., 2017).

NMDAR blockade is thought to underlie the dissociative anesthetic and amnesic effects of ketamine, as well 


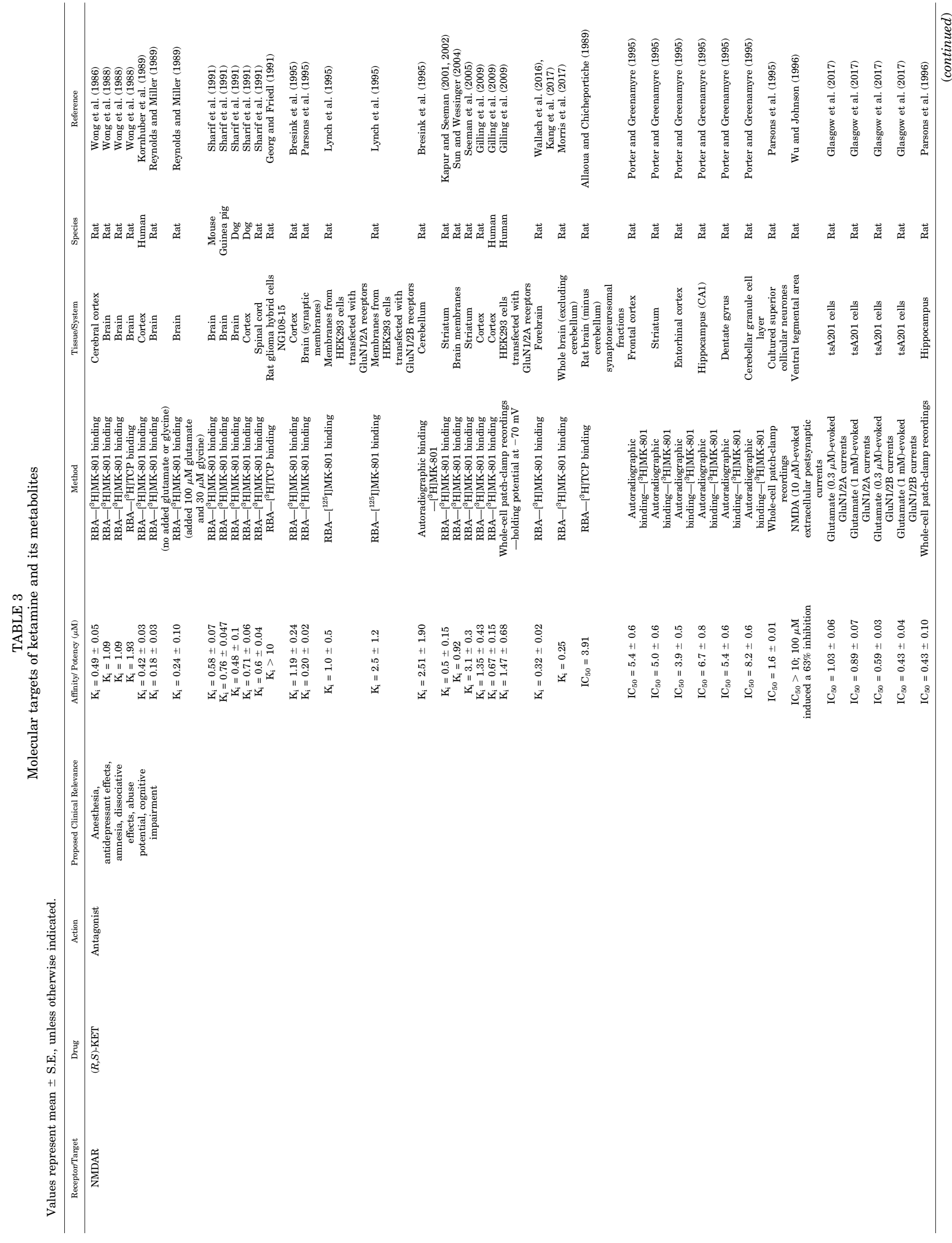




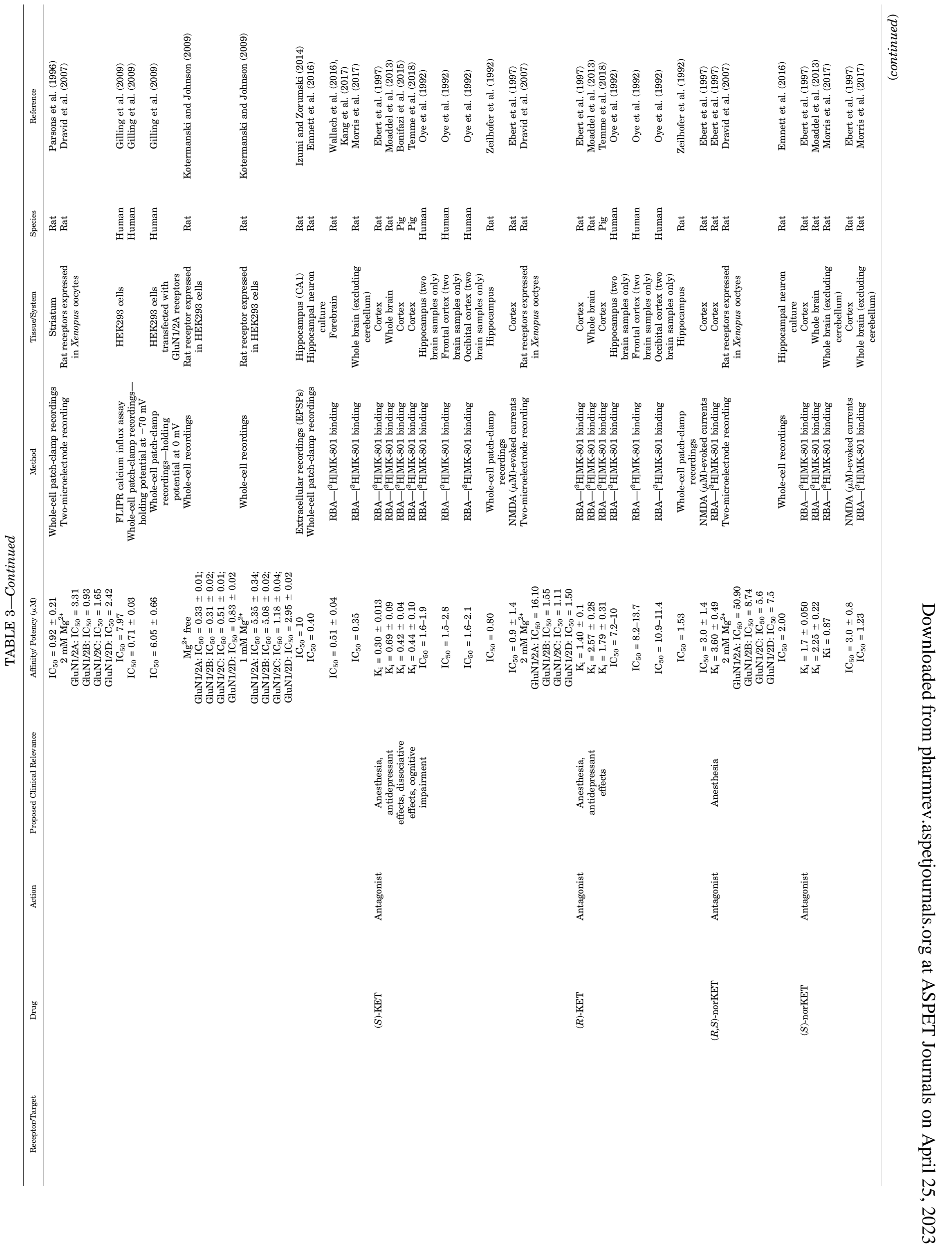




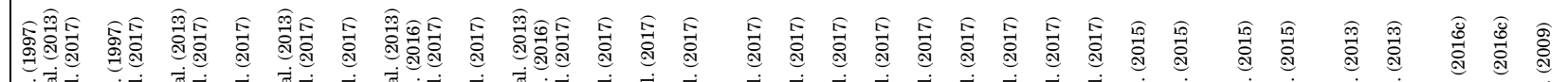

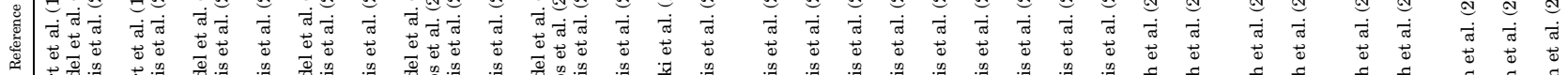

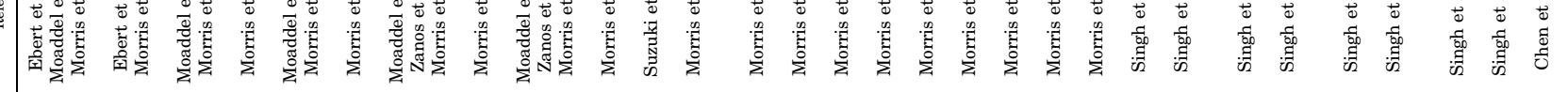

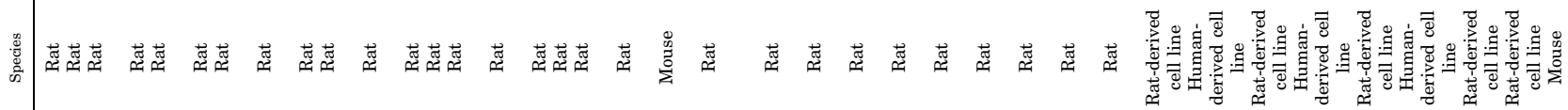

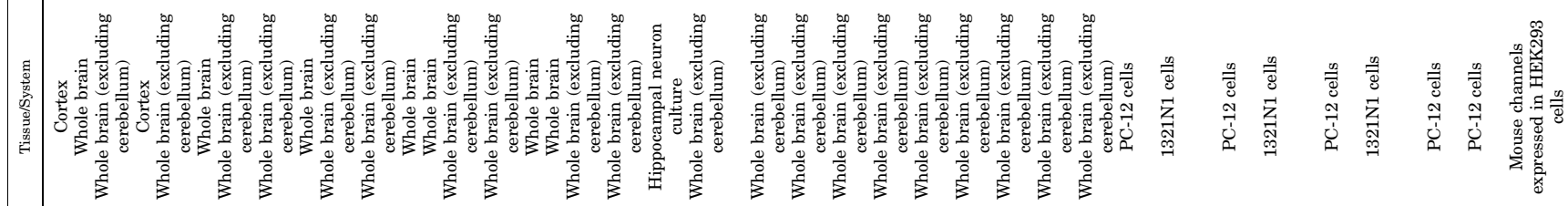

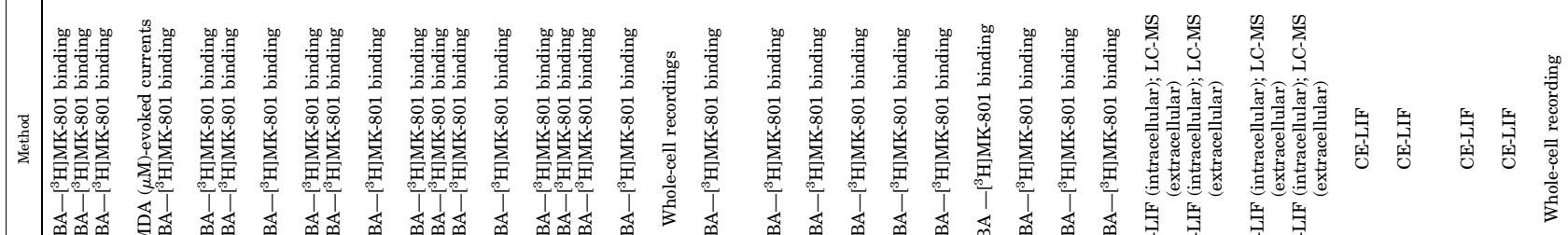

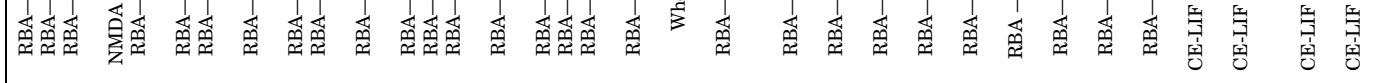

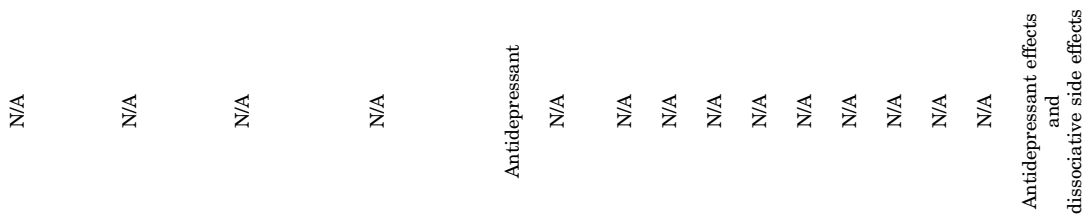

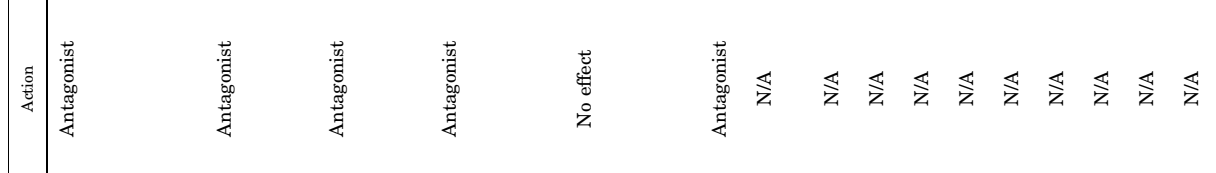<smiles>F[C@H]1CC[C@@H]1F</smiles>

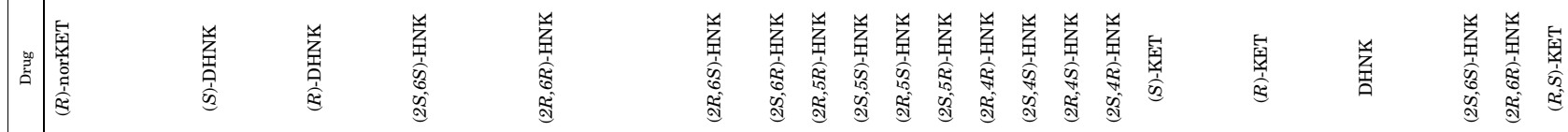




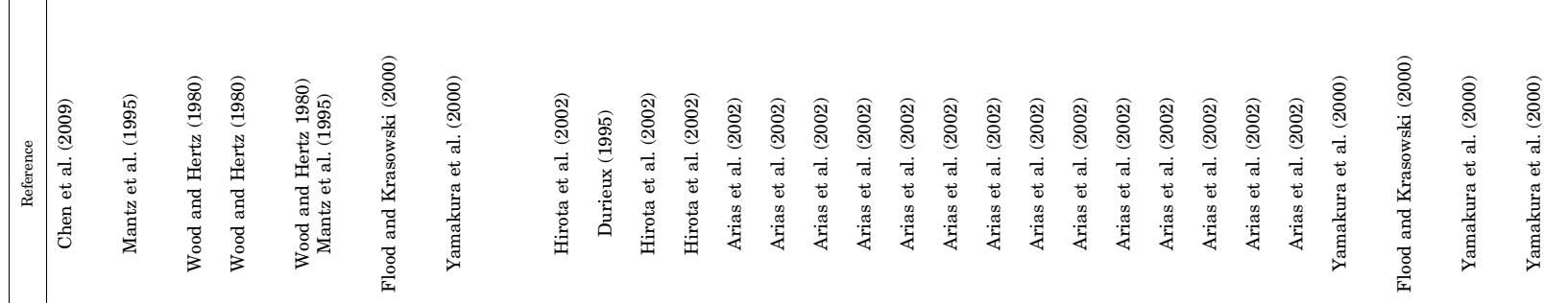

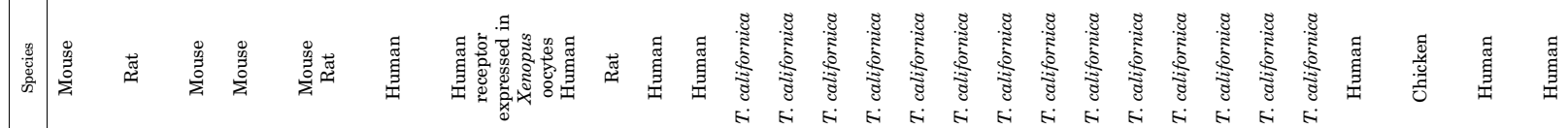

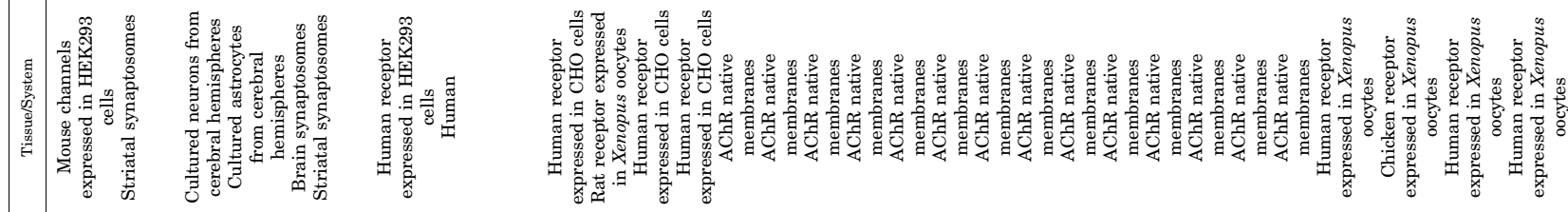

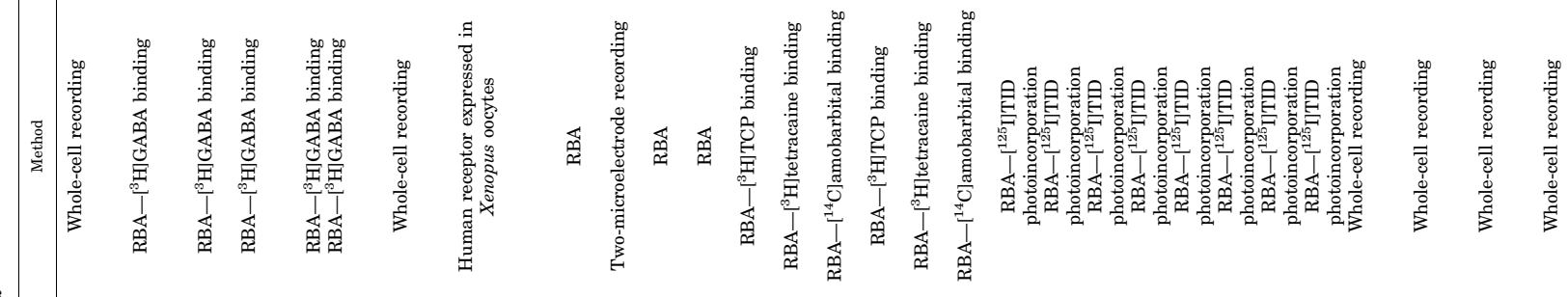

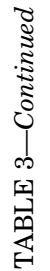

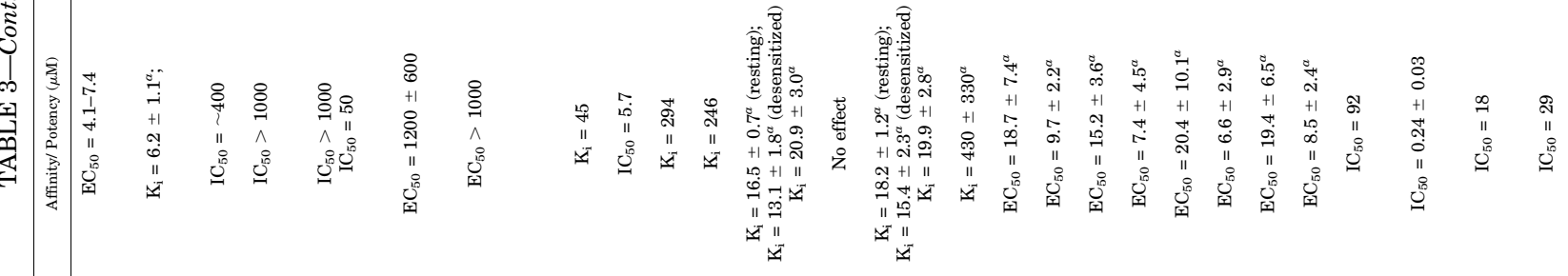

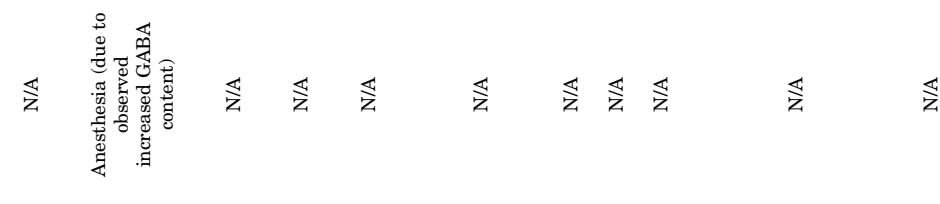

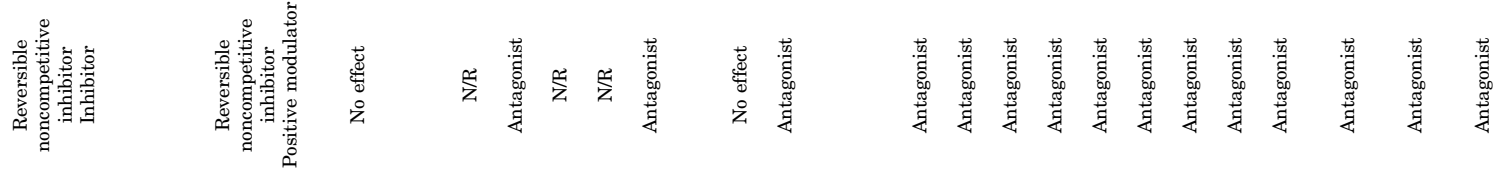

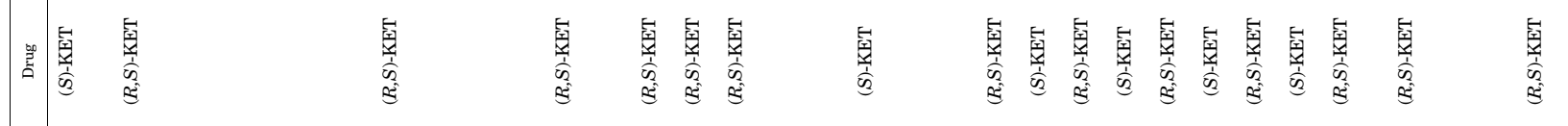

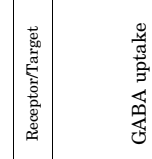

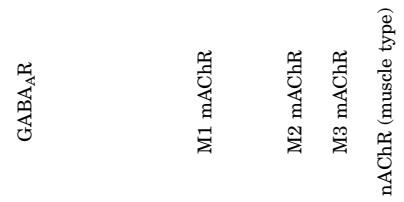

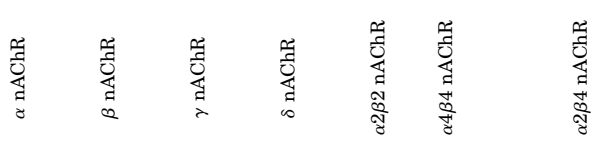




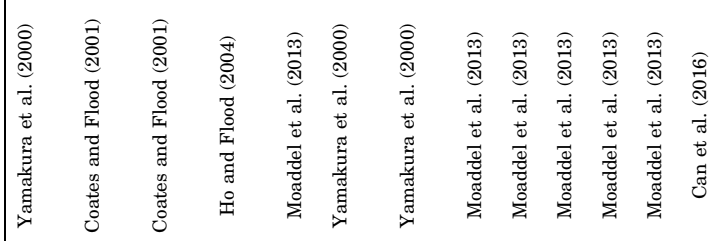

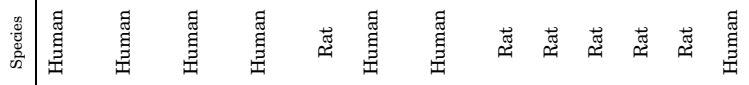

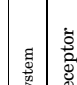

离

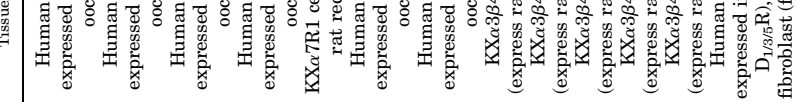

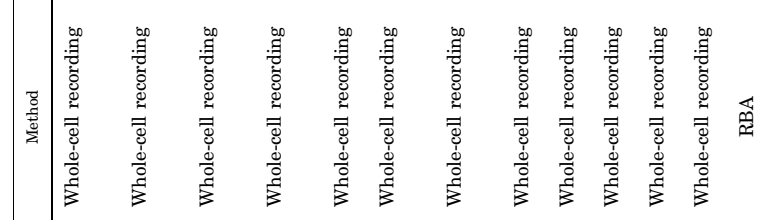

范

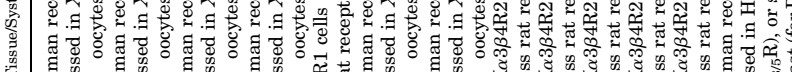

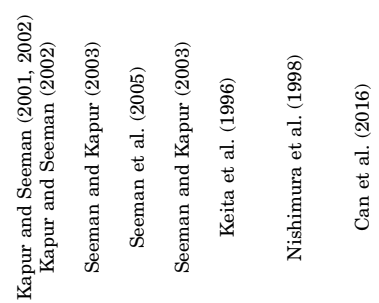

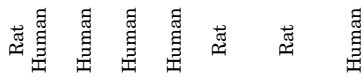

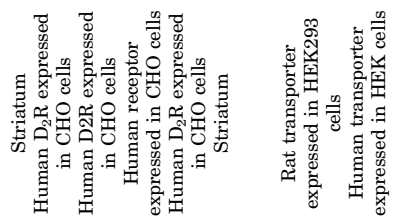

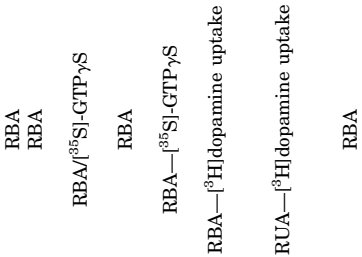

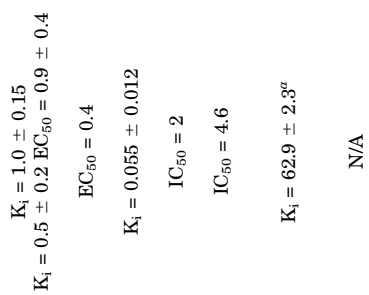

窟

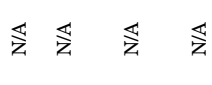

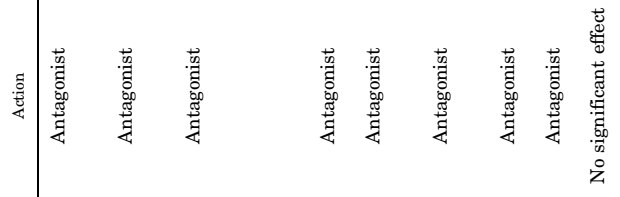

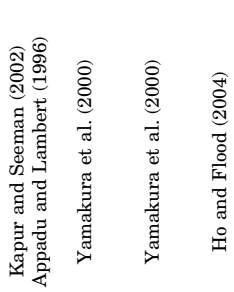

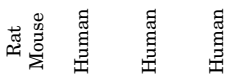

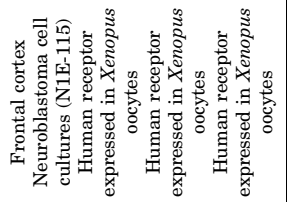

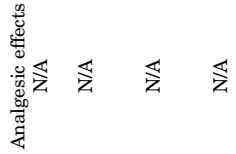

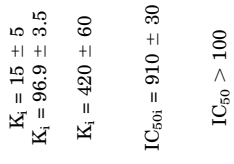

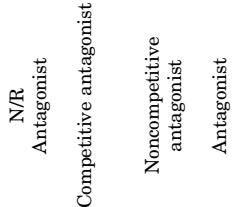

$\widehat{z}$

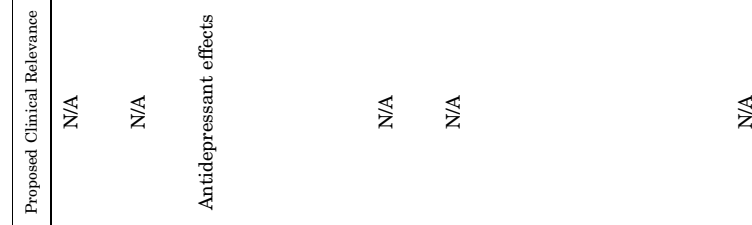

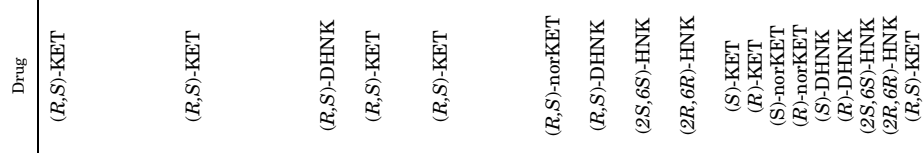

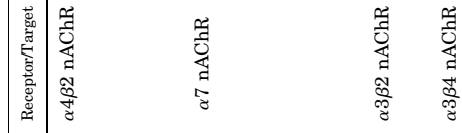

告 


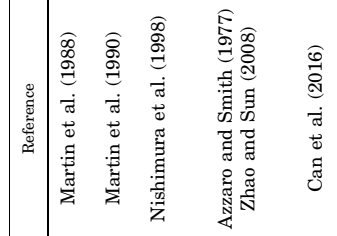

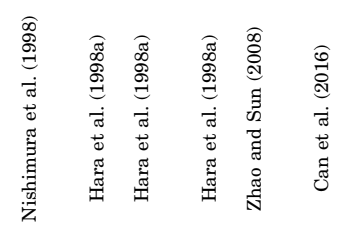

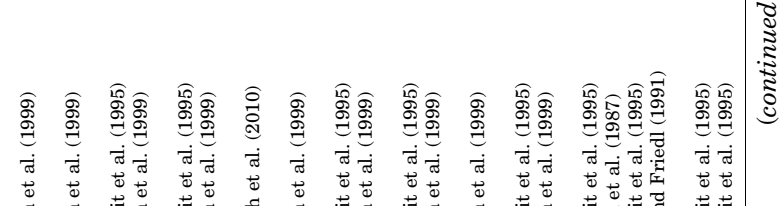

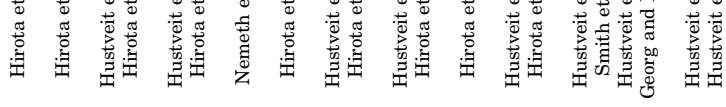

营

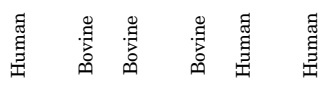

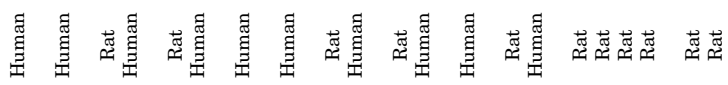

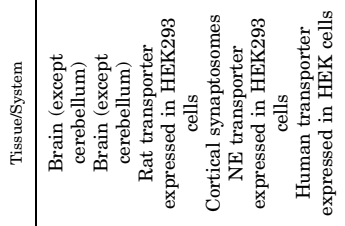

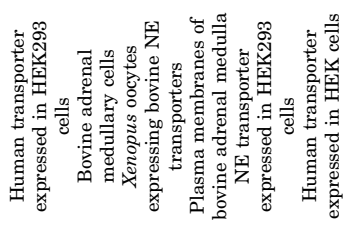

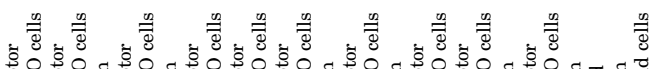

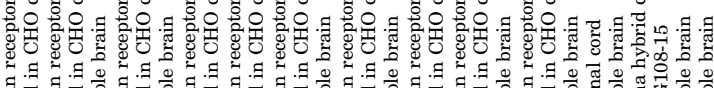

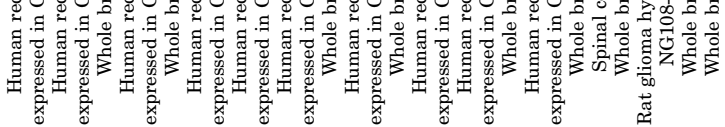

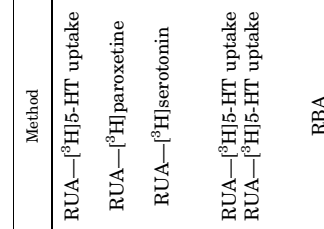

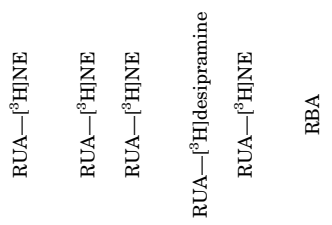

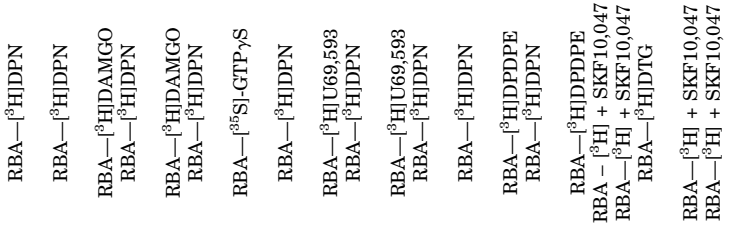

胥

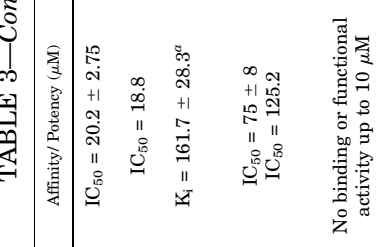

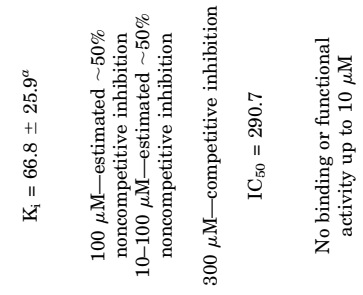

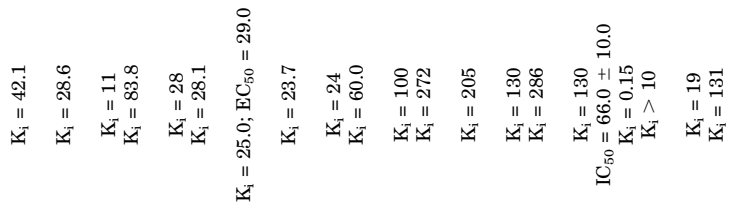

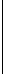

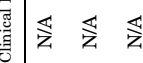

$\stackrel{\mathbb{3}}{\mathrm{z}}$

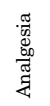

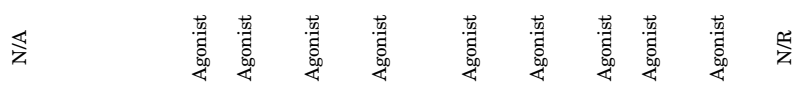

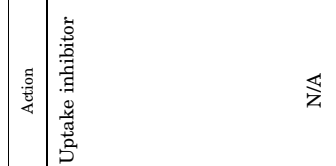

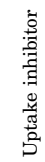

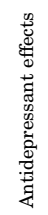

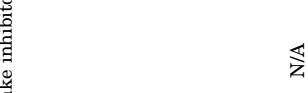

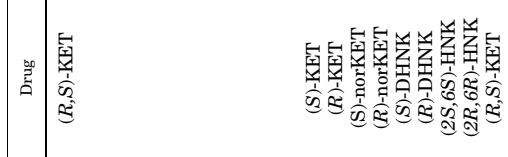

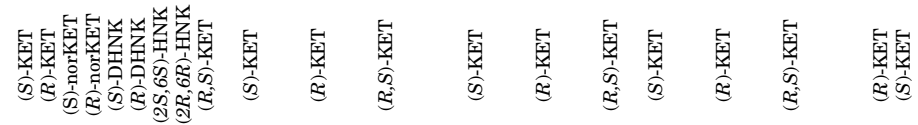

䓢

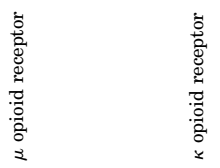

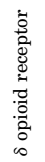




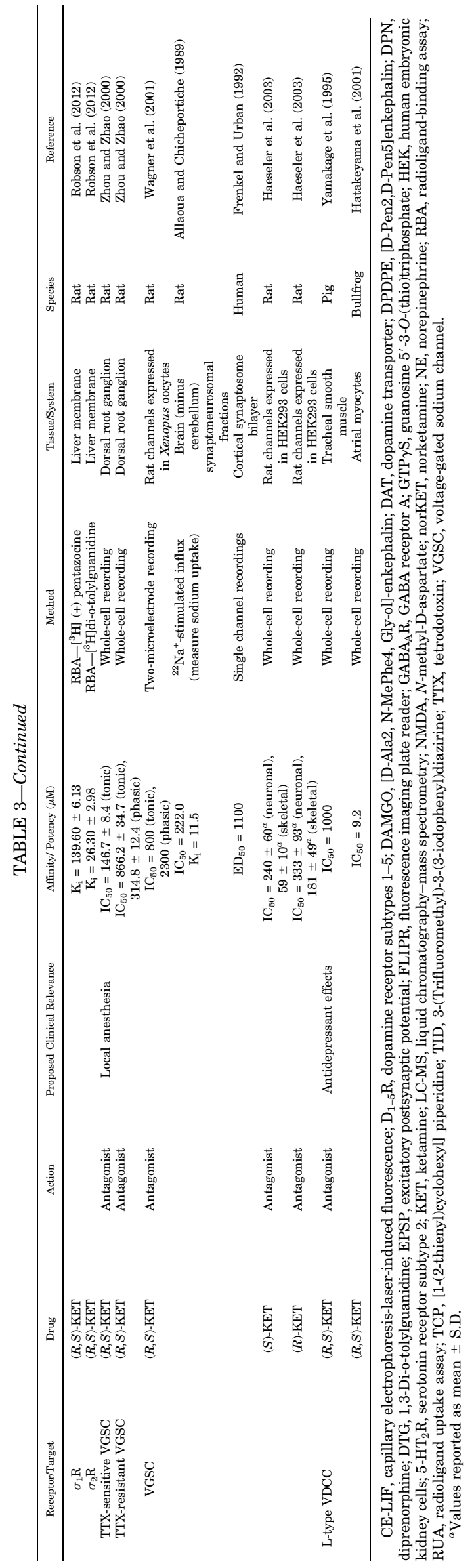


as the antidepressant, analgesic, and altered psychotomimetic effects induced by the drug (White et al., 1980; Oye et al., 1992; Yeung et al., 2010; Li et al., 2010, Autry et al., 2011; Miller et al., 2014). Ketamine-induced cognitive deficits are also hypothesized to be due to NMDAR inhibition (Shaffer et al., 2014). (S)-ketamine has an approximately fourfold higher affinity/potency for the PCP site of the NMDAR compared with the $(R)$-isomer, and twice that of the racemic mixture $[(S)$-ketamine: $\mathrm{K}_{\mathrm{i}}=0.3-0.69 \mu \mathrm{M} ;(R)$-ketamine: $\mathrm{K}_{\mathrm{i}}=1.4-2.57 \mu \mathrm{M}$; and $(R, S)$-ketamine: $\mathrm{K}_{\mathrm{i}}=0.18-3.1 \mu \mathrm{M}$, in the presence of extracellular $\mathrm{Mg}^{2+}$ (Ebert et al., 1997; Kohrs and Durieux, 1998; Moaddel et al., 2013; Zanos et al., 2016; Temme et al., 2018)]. The effects of $(S)$-ketamine and $(R)$-ketamine were also assessed on NMDA receptor-activated cation currents of whole-cell voltage-clamped cultured rat hippocampal neurons (Zeilhofer et al., 1992). These authors showed that both enantiomers exhibited voltageand use-dependent blockades of NMDAR currents, with $(S)$-ketamine being about twice as potent compared with $(R)$-ketamine $\left(\mathrm{IC}_{50}=0.80\right.$ versus $1.53 \mu \mathrm{M}$, respectively; Zeilhofer et al., 1992). Moreover, (S)-ketamine has 2.53 times higher potency to inhibit NMDA-evoked currents in cat dorsal horn neurons compared with the $(R)$-ketamine enantiomer (Lodge et al., 1982). This higher affinity/ potency of the $(S)$-ketamine isomer is hypothesized to explain why $(S)$-ketamine is a more potent anesthetic than $(R, S)$-ketamine (Yamakura and Shimoji, 1999). Consistent with these stereospecific differential potencies to inhibit the NMDAR by ketamine's isomers, the $\mathrm{ED}_{50}$ value for induction of hypnosis (loss of righting reflex) was lower for $(S)$-ketamine and $(R, S)$-ketamine (3.5 and $5.6 \mathrm{mg} / \mathrm{kg}$, respectively) compared with $(R)$ ketamine (10.3 mg/kg; Marietta et al., 1977). Similarly, Ryder et al. (1978) showed that $(S)$-ketamine is an $\sim 3$ times more potent analgesic, 1.5 times more potent hypnotic (loss of righting reflex) and 1.8 times more potent locomotor stimulant agent compared with $(R)$ ketamine. In particular, the median effective analgesic (s.c.) doses were found to be $6.5,3.7$ and $11 \mathrm{mg} / \mathrm{kg}$ for $(R, S)$-ketamine, $(S)$-ketamine and $(R)$-ketamine, respectively (Ryder et al., 1978). The median hypnotic doses for $(R, S)$-ketamine, $(S)$-ketamine and $(R)$-ketamine were calculated to be 45,38 and $56 \mathrm{mg} / \mathrm{kg}$, respectively (Ryder et al., 1978). In addition, $(S)$-ketamine ( $25 \mathrm{mg} / \mathrm{kg}$, s.c.) induced a more profound disruption in sensorimotor gating compared with the $(R)$-ketamine $(25 \mathrm{mg} / \mathrm{kg}$, s.c.) enantiomer in the rat pre-pulse inhibition paradigm, although $(R)$-ketamine also showed a subtle effect in this study compared with the control-treated rats (Littlewood et al., 2006). In agreement with this finding, Yang et al. (2015) showed disruption of sensorimotor gating and hyperlocomotion to only occur from administration of $(S)$-ketamine, but not $(R)$-ketamine in mice. Subanesthetic concentrations of ketamine (40-minute i.v. infusion; $0.5 \mathrm{mg} / \mathrm{kg}$ ), which exert antidepressant actions in patients suffering from major depression (Zarate et al., 2012a), resulted in a maximum of $31 \% \pm 18 \%$ NMDAR occupancy (Shaffer et al., 2014). This occupancy is similar to the NMDAR occupancy estimated $(32 \% \pm 6 \%$ maximum; Shaffer et al., 2014) following an antidepressant-relevant dose of ketamine in rats $(10 \mathrm{mg} / \mathrm{kg}$, i.p.; Yeung et al., 2010). Nevertheless, $(R)$-ketamine was reported to be a more potent and longer-lasting antidepressant compared with the $(S)$-ketamine enantiomer in several rodent models (Zhang et al., 2014; Yang et al., 2015; Zanos et al., 2016; Fukumoto et al., 2017), when using a 30-fold dose range (Zanos et al., 2016). There do not appear to be differences in brain exposure of the two enantiomers (Zanos et al., 2016; Fukumoto et al., 2017), thus challenging the NMDAR inhibition hypothesis as the sole mediator of the antidepressant actions of ketamine.

In membrane fractions of postmortem human brain homogenates, $\mathrm{IC}_{50}$ values for $\left[{ }^{3} \mathrm{H}\right] \mathrm{MK}-801$ displacement by $(S)$ - and $(R)$-ketamine were reported to be $1.6-1.9$ and $7.2-10 \mu \mathrm{M}$, respectively, in the presence of extracellular $\mathrm{Mg}^{2+}$ (Oye et al., 1992). Similarly, in rat cortical tissue $(S)$-ketamine inhibited NMDA (10 $\mu \mathrm{M})$-evoked currents with an $\mathrm{IC}_{50}$ of $0.9 \pm 1.4 \mu \mathrm{M}$, whereas $(R)$-ketamine was a less potent inhibitor with an $\mathrm{IC}_{50}$ of $3.0 \pm 1.4 \mu \mathrm{M}$ (Ebert et al., 1997). Whole-cell patch-clamp electrophysiological recordings obtained from human embryonic kidney (HEK)293T cells transfected with different NMDAR subunits revealed that, in the absence of extracellular $\mathrm{Mg}^{2+}$, ketamine inhibits the NMDARs containing GluN1/ GluN2A $\left(\mathrm{IC}_{50}=0.33 \pm 0.01 \mu \mathrm{M}\right)$ and GluN1/GluN2B $\left(\mathrm{IC}_{50}=0.31 \pm 0.02 \mu \mathrm{M}\right)$ subunit compositions with a modestly higher potency than GluN1/GluN2C $\left(\mathrm{IC}_{50}=\right.$ $0.51 \pm 0.01 \mu \mathrm{M})$ and GluN1/GluN2D $\left(\mathrm{IC}_{50}=0.83 \pm 0.02\right.$ $\mu \mathrm{M}$ ) subunits (Kotermanski and Johnson, 2009). In contrast, in the presence of physiologic levels of $\mathrm{Mg}^{2+}$ ( $1 \mathrm{mM})$, ketamine blocks NMDAR containing GluN1/ GluN2C $\left(\mathrm{IC}_{50}=1.18 \pm 0.0 \mu \mathrm{M}\right)$ and GluN1/GluN2D $\left(\mathrm{IC}_{50}=2.95 \pm 0.02 \mu \mathrm{M}\right)$ subunits, with a higher potency than the GluN1/GluN2A $\left(\mathrm{IC}_{50}=5.35 \pm 0.34 \mu \mathrm{M}\right)$ and GluN1/GluN2B $\left(\mathrm{IC}_{50}=5.08 \pm 0.02 \mu \mathrm{M}\right)$ subunits (Kotermanski and Johnson, 2009). Nevertheless, Yamakura et al. (1993) failed to identify differences in ketamineinduced inhibition of the different NMDAR receptor subunits in Xenopus oocytes injected with subunitspecific mRNAs synthesized in vitro. These findings highlight a lack of clarity on any differential effects of ketamine on NMDAR subtypes composed of different subunits.

Studies have shown that $(S)$-ketamine inhibits NMDARs composed of GluN1/GluN2C $\left(\mathrm{IC}_{50}=1.11 \mu \mathrm{M}\right)$ and GluN1/ GluN2D $\left(\mathrm{IC}_{50}=1.50 \mu \mathrm{M}\right)$ with higher potency than those composed of GluN1/GluN2A $\left(\mathrm{IC}_{50}=16.10 \mu \mathrm{M}\right)$ in the presence of $2 \mathrm{mM} \mathrm{Mg}^{2+}$ (Dravid et al., 2007). $(S)$-ketamine's potency to inhibit GluN1/GluN2B $\left(\mathrm{IC}_{50}=\right.$ $1.55 \mu \mathrm{M})$ is reported to be similar to its potency to inhibit GluN1/GluN2C- and GluN1/GluN2D-containing NMDARs in the presence of $2 \mathrm{mM} \mathrm{Mg}{ }^{2+}$ (Dravid et al., 2007). These findings indicate that any preferential potency of 
ketamine is likely not the result of higher affinity of ketamine to bind to the GluN2C-NMDARs per se, but may be due to differential capacity for $\mathrm{Mg}^{2+}$ binding, or interactions between the drug and $\mathrm{Mg}^{2+}$ within the channel (Kotermanski and Johnson, 2009; Kotermanski et al., 2009). Thus, ketamine may differentially block specific NMDAR subtypes in the brain depending upon local $\mathrm{Mg}^{2+}$ concentrations. In support of this concept, in the absence of $\mathrm{Mg}^{2+}$, ketamine blocks GluN2Bcontaining NMDARs with a higher potency compared with the NMDARs containing other GluN2 subunits, as measured using recombinant NMDAR GluN2A-D subunits expressed in Xenopus oocytes (Dravid et al., 2007).

In the presence of extracellular $\mathrm{Mg}^{2+}$, ketamine's $\mathrm{N}$-demethylated metabolite, norketamine, also inhibits the NMDAR. $(S)$-norketamine has a reported $\mathrm{K}_{\mathrm{i}}$ of 1.70 $2.25 \mu \mathrm{M}$ for NMDARs in the spinal cord and the cerebral cortex, whereas $(R)$-norketamine has an approximately eight times lower binding affinity $\left(\mathrm{K}_{\mathrm{i}}=13.0-26.46 \mu \mathrm{M}\right.$; Ebert et al., 1997; Moaddel et al., 2013); also see Table 3. In accordance with these findings, $(S)$-norketamine $\left(\mathrm{IC}_{50}=3.0 \pm 0.8 \mu \mathrm{M}\right)$ more potently inhibited NMDA $(10 \mu \mathrm{M})$-evoked currents than $(R)$-norketamine $\left(\mathrm{IC}_{50}=\right.$ $39 \pm 1.4 \mu \mathrm{M}$ ) in rat cerebral cortical neurons (Ebert et al., 1997). Therefore, because NMDAR inhibition was considered the primary mechanism of action of ketamine, the clinical effects of the drug were initially attributed to ketamine and norketamine (Leung and Baillie, 1986; Hirota and Lambert, 2011; Singh et al., 2014).

DHNK and HNK metabolites display weak or no ability to displace $\left[{ }^{3} \mathrm{H}\right] \mathrm{MK}-801$ binding to NMDARs. $(R)$-DHNK has lower affinity than $(S)$-DHNK (59.7-74.6 and 39.0-42.0 $\mu \mathrm{M}$, respectively) for displacing $\left[{ }^{3} \mathrm{H}\right] \mathrm{MK}-801$ binding to the NMDAR (Moaddel et al., 2013; Morris et al., 2017). (2S,6S)-HNK has a $\mathrm{K}_{\mathrm{i}}=10.4-21.0 \mu \mathrm{M}$ for displacing $\left[{ }^{3} \mathrm{H}\right] \mathrm{MK}-801$ binding, whereas $(2 R, 6 R)$-HNK does not bind to the NMDAR-PCP site with appreciable affinity $\left(\mathrm{K}_{\mathrm{i}}>100 \mu \mathrm{M}\right.$; Moaddel et al., 2013; Morris et al., 2017). In addition, at concentrations up to $10 \mu \mathrm{M}$, neither $(2 S, 6 S)$-HNK nor $(2 R, 6 R)$-HNK functionally inhibit NMDA-evoked currents in rat hippocampal interneurons (Zanos et al., 2016). Lack of functional NMDAR inhibition by $(2 R, 6 R)$-HNK at $10 \mu \mathrm{M}$ was also reported by Suzuki et al. (2017). At a higher concentration $(50 \mu \mathrm{M})$, $(2 R, 6 R)$-HNK moderately $(\sim 40 \%)$ inhibited NMDARmediated miniature excitatory postsynaptic currents recorded from cultured hippocampal neurons in the absence of $\mathrm{Mg}^{2+}$. This finding supported the contention that, at concentrations higher than those relevant to antidepressant treatment and in the absence of $\mathrm{Mg}^{2+}$, (2R,6R)-HNK might functionally inhibit NMDARs (Suzuki et al., 2017; Zanos et al., 2017a). Notably, at the same concentration $(50 \mu \mathrm{M})$ and under the same experimental conditions, ketamine induced $>90 \%$ inhibition of NMDAR-mediated miniature excitatory postsynaptic currents recorded from hippocampal neurons
(Suzuki et al., 2017). (2R,6S)-, (2S,6R)-, $(2 R, 5 R)-,(2 S, 5 S)$-, $(2 S, 5 S)_{-},(2 R, 5 S)_{-},(2 S, 5 R)-,(2 R, 4 S)-,(2 S, 4 R)-,(2 R, 4 R)_{-}$, and $(2 S, 4 S)$-HNKs do not have significant affinity to displace $\left[{ }^{3} \mathrm{H}\right] \mathrm{MK}-801$ binding $\left(\mathrm{K}_{\mathrm{i}}>100 \mu \mathrm{M}\right.$; Morris et al., 2017).

There is also evidence that, by reducing extracellular levels of D-serine, ketamine's enantiomers and its metabolites may indirectly decrease the activation of NMDARs (Singh et al., 2013). D-serine, an endogenous NMDAR coagonist that binds to the glycine ${ }_{B}$ site, is required for activation of the NMDAR complex (Paoletti et al., 2013) and is produced by enzymatic L-serine enantioconversion catalyzed by serine racemase (Wolosker et al., 2008). Incubation of PC-12 cells with increasing concentrations of $(S)$ - and $(R)$-ketamine exerted differential effects on the intracellular and extracellular D-serine levels. Specifically, application of $(S)$-ketamine was associated with increased intracellular D-serine $\left(\mathrm{EC}_{50}=0.82 \pm 0.29 \mu \mathrm{M}\right)$ and decreased extracellular levels of D-serine $\left(\mathrm{IC}_{50}=0.82 \pm 0.29 \mu \mathrm{M}\right.$; Singh et al., 2015). In contrast, $(R)$-ketamine decreased both intracellular $\left(\mathrm{IC}_{50}=0.94 \pm 0.16 \mu \mathrm{M}\right)$ and extracellular levels of D-serine $\left(\mathrm{IC}_{50}=0.70 \pm 0.10 \mu \mathrm{M}\right.$; Singh et al., 2015; Table 3). Similar findings were observed using $1321 \mathrm{~N} 1$ cells and primary hippocampal and cortical neuronal cells. Singh et al. (2015) also demonstrated that inhibition of the amino acid transporter, ASCT2, resulted in qualitatively similar effects to those induced by $(S)$-ketamine on D-serine levels. In addition, coincubation with sub-saturating concentrations of an ASCT2 inhibitor and $(S)$-ketamine resulted in an additive effect in both PC-12 cells and primary neuronal cells in regard to D-serine levels, indicating that the effects of $(S)$-ketamine might be due to an inhibition of the amino acid transporter systems.

The differential effects of ketamine's enantiomers on D-serine levels might contribute to their differential behavioral effects. Indeed, whereas $(S)$-ketamine is a more potent anesthetic and analgesic drug (Marietta et al., 1977; White et al., 1985) than $(R)$-ketamine, $(R)$ ketamine is a more potent and longer-lasting antidepressant than $(S)$-ketamine in several animal tests (Zhang et al., 2014; Yang et al., 2015; Zanos et al., 2016; Fukumoto et al., 2017). In fact, D-serine plays a role in synaptic plasticity (Henneberger et al., 2010), and baseline plasma D-serine levels are negatively correlated with ketamine treatment response in patients suffering from major depression (Moaddel et al., 2015a), indicating a possible role of $\mathrm{D}$-serine levels in the antidepressant responses of ketamine (also see Hashimoto, 2014). In vivo, sub-chronic (14-day) administration of ketamine to rats was shown to reduce serine racemase mRNA levels in the forebrain (Watanabe et al., 2010). However, a single administration of ketamine at the dose of $50 \mathrm{mg} / \mathrm{kg}$ resulted in an enhancement of serine racemase mRNA levels in the striatum, hippocampus, and cortex of rats (Takeyama et al., 2006), an effect that is 
predicted to induce an increase rather than a decrease in D-serine levels. Indeed, a single administration of (R)-ketamine (10 mg/kg, i.p.) slightly, but significantly increased cortical D-serine/L-serine ratio in mice $(\mathrm{Ma}$ et al., 2017). Therefore, further in vivo confirmation of the effects of ketamine and its enantiomers on D-serine levels is warranted.

DHNK has also been shown to modify D-serine levels. Singh et al. (2013) demonstrated that incubation of PC-12 and 1321N1 cells with 5-90 nM DHNK decreased the relative intracellular $\mathrm{D}$-serine concentrations. Because DHNK is not produced in the brain and does not cross the blood-brain barrier in ketamine-treated rodents (Can et al., 2016; Moaddel et al., 2016), the behavioral relevance of this metabolite's actions on $\mathrm{D}$-serine levels is not clear (Zanos et al., 2016).

HNKs are also capable of reducing intracellular $\mathrm{D}$-serine concentrations in $\mathrm{PC}-12$ cells, with $(2 S, 6 S)$ $\mathrm{HNK}$ being more potent than $(2 R, 6 R)$-HNK $\left(\mathrm{IC}_{50} \mathrm{~S}\right.$ are reported to be $0.18 \pm 0.04$ and $0.68 \pm 0.09 \mathrm{nM}$, respectively; Singh et al., 2016c). It is possible that the HNK-induced reduction of intracellular D-serine levels may also result in a reduction of extracellular levels of this amino acid. However, modulation of extracellular levels of $\mathrm{D}$-serine may not be an important determinant of the antidepressant effects of HNKs, because at least in mice, $(2 R, 6 R)$-HNK exerts more potent antidepressant actions than (2S,6S)-HNK (Zanos et al., 2016) and DHNK (Sałat et al., 2015). In addition, electrophysiological studies failed to identify any inhibitory effects of antidepressant-relevant concentrations of these metabolites on NMDAR function (Zanos et al., 2016, 2017b; Suzuki et al., 2017), as decreased extracellular D-serine levels would predict. Moreover, acute D-serine administration induces ketamine-like antidepressant behavioral and biochemical responses in rats (Wei et al., 2017), further complicating the possible functional role of decreased extracellular D-serine levels following ketamine administration. Further verification, possibly using human brain-derived cells or measuring extracellular D-serine levels in vivo following administration of ketamine and/or its metabolites, would be informative in determining the functional relevance of these results.

\section{B. Hyperpolarization-Activated Cyclic Nucleotide- Gated Channels}

HCN channels are voltage-gated cation channels (HCN1-HCN4; Luthi and McCormick, 1998; Wahl-Schott and Biel, 2009). Activation of these channels by membrane hyperpolarization is facilitated by cyclic nucleotides, including cAMP. In the central nervous system, HCN channels play a major role in controlling neuronal excitability, synaptic activity, and rhythmic oscillations (Shah, 2014).

There is a report of subunit-specific inhibitory effects of ketamine $\left(\mathrm{EC}_{50}=8.2-15.6 \mu \mathrm{M}\right)$ on $\mathrm{HCN} 1-\mathrm{HCN} 2$ heteromeric channels and hyperpolarization-activated pacemaker currents $\left(I_{\mathrm{h}}\right.$; Chen et al., 2009). This may be relevant to the anesthetic actions of ketamine, as ketamine-induced anesthesia was significantly suppressed in HCN knockout mice (Chen et al., 2009). Additionally, $(S)$-ketamine was found to be more potent at inhibiting these channels $\left(\mathrm{EC}_{50}=4.1-7.4 \mu \mathrm{M}\right)$ compared with racemic ketamine $\left(\mathrm{EC}_{50}=8.2-15.6 \mu \mathrm{M}\right.$; Chen et al., 2009), concordant with the greater anesthetic potency of $(S)$-ketamine. Indeed, it has been hypothesized that NMDAR inhibition is not the sole mechanism underlying the anesthetic properties of ketamine (Petrenko et al., 2014). Further studies are required to substantiate the exact role of HCN channel inhibition in this regard, and to replicate these findings.

In addition to a possible role in the anesthetic properties of ketamine, HCN1 channel inhibition may have a role in ketamine's antidepressant actions because reduced HCN1 activity in the hippocampus has been associated with antidepressant effects in rodents (Lewis et al., 2011; Kim et al., 2012; Han et al., 2017). Of interest, mice lacking the HCN1 gene did not manifest ketamine-induced reductions in immobility time in the forced-swim test following chronic oral corticosterone treatment ( $\mathrm{Li}$ et al., 2014). Furthermore, following ketamine administration, these mice did not show increased sucrose preference or decreased latency to feed in the novelty-suppressed feeding test (Zhang et al., 2016). Unfortunately, these results cannot be unambiguously interpreted as evidence that HCN1 mediates the antidepressant effects of ketamine because HCN1 deletion by itself induced baseline behavioral changes compatible with reduced depressive-like behavior (e.g., decreased immobility in the forced-swim test). In addition, Zhang et al. (2016) suggested that reduction of HCN1 function by ketamine was secondary to inhibition of presynaptic NMDARs. The authors did not test the hypothesis that direct inhibition of HCN1 by ketamine, as was suggested by Petrenko et al. (2014), accounts for its antidepressant effects. There are currently no published data on the activity of ketamine's metabolites on the function of HCN1 channels or the involvement of these channels on the behavioral effects of these metabolites.

\section{GABA Uptake and GABA Receptors}

The primary inhibitory neurotransmitter, GABA, activates both the ionotropic GABA receptor subtypes $\mathrm{A}$ and $\mathrm{C}\left(\mathrm{GABA}_{\mathrm{A}}\right.$ and $\left.\mathrm{GABA}_{\mathrm{C}}\right)$ and the metabotropic GABA receptor subtype $B\left(\mathrm{GABA}_{\mathrm{B}}\right)$ in the brain (Jacob et al., 2008). Electrophysiological studies have revealed that high concentrations of ketamine potentiate GABAergic inhibitory postsynaptic currents in neurons of guinea pig olfactory cortical slices (300 $\mu \mathrm{M}$; Scholfield, 1980) and of rat hippocampal slices (500 $\mu \mathrm{M}$; Gage and Robertson, 1985). At high concentrations, ketamine potentiates GABA-activated $\mathrm{GABA}_{\mathrm{A}}$ receptors ectopically expressed 
in Xenopus oocytes (365 $\mu \mathrm{M}$; Lin et al., 1992) and HEK293 cells $\left(>500 \mu \mathrm{M} ; \mathrm{EC}_{50}=1.2 \mathrm{mM}\right.$; Flood and Krasowski, 2000; but see Anis et al., 1983). There is also evidence for an inhibitory effect of ketamine on GABA uptake $\left(\mathrm{K}_{\mathrm{i}}=\right.$ $\left.6.2 \pm 1.1 ; \mathrm{IC}_{50}=50 \mu \mathrm{M}\right)$, as assessed by the $\left[{ }^{3} \mathrm{H}\right] \mathrm{GABA}-$ binding assay in striatal synaptosomes of rats (Mantz et al., 1995), indicating that ketamine might cause an increase in extracellular GABA levels. Indeed, it was shown that intramuscular administration of ketamine to rats increases GABA content in the brain and in synaptosomal-enriched fractions of the brain (Wood and Hertz, 1980). However, the effect of ketamine on GABA uptake was not found at clinically relevant concentrations in mice $\left(\mathrm{IC}_{50}>1000 \mu \mathrm{M}\right.$; Wood and Hertz, 1980).

The functional relevance of the actions of ketamine on $\mathrm{GABA}_{\mathrm{A}}$ receptors is not clear because ketamine concentrations required to modify the activity of these receptors are much higher than those achieved following ketamine administration in clinical settings for anesthetic, analgesic, anti-inflammatory, and antidepressant effects. Nevertheless, there is preclinical evidence for both agonist and antagonist properties of ketamine at $\mathrm{GABA}_{\mathrm{A}}$ receptors. For example, peripheral administration of subthreshold doses of ketamine $(0.1 \mathrm{mg} / \mathrm{kg}$, i.p. $)$ combined with the $\mathrm{GABA}_{\mathrm{A}}$ receptor agonist muscimol $(0.1 \mathrm{mg} / \mathrm{kg}$, i.p. $)$ induced a synergistic antidepressant behavioral response in the acute (30 minutes postinjection) forced-swim test in mice (Rosa et al., 2016). In contrast, direct infusion of muscimol into the infralimbic prefrontal cortex abolished the sustained (24 hours postinjection) antidepressant behavioral effects of ketamine in rats (Fuchikami et al., 2015), suggesting that the in vivo interaction between ketamine and $\mathrm{GABA}_{\mathrm{A}}$ receptors might be brain region specific. In addition, ketamine-associated delirium occurring at anesthetic doses (1-2 mg/kg, i.v. infusion) is effectively minimized via pretreatment with benzodiazepines (positive allosteric modulators of $\mathrm{GABA}_{\mathrm{A}}$ receptors; Dundee and Lilburn, 1978; Perumal et al., 2015). In contrast, Irifune et al. (2000) showed that both muscimol and the benzodiazepine receptor agonist diazepam augment ketamine-induced anesthesia, whereas the $\mathrm{GABA}_{\mathrm{A}}$ receptor antagonist bicuculline antagonizes ketamineinduced anesthesia in mice. Finally, at subanesthetic doses, ketamine does not bind to $\mathrm{GABA}_{\mathrm{A}}$ receptors in the human brain, as assessed by positron emission tomography (PET) scan imaging (Salmi et al., 2005), and does not alter $\mathrm{GABA}_{\mathrm{A}}$ receptor function at anestheticrelevant concentrations (i.e., $10 \mu \mathrm{M}$ ) in HEK293 cells in vitro (Flood and Krasowski, 2000). These findings indicate that, at least at subanesthetic doses, ketamine itself might only indirectly affect $\mathrm{GABA}_{\mathrm{A}}$ receptor activity to exert any relevant behavioral effects. Indeed, it is postulated that ketamine-induced dissociation/ psychotomimetic effects are due to NMDAR blockade on GABAergic inhibitory interneurons, an action that is presumed to disinhibit excitatory neurotransmission via decreased GABA release, and to consequently reduce activation of the $\mathrm{GABA}_{\mathrm{A}}$ receptors in glutamatergic synapses (Moghaddam et al., 1997; Farber et al., 1998; Homayoun and Moghaddam, 2007; Hare et al., 2017; Wohleb et al., 2017).

\section{Cholinergic Receptors}

Ketamine is reported to bind to both muscarinic and nicotinic acetylcholine receptors (mAChRs and nAChRs, respectively). To date, five subtypes of mAChRs have been identified (M1-M5). These are metabotropic receptors that signal primarily, although not exclusively, through $\mathrm{G}_{\alpha \mathrm{i} / \mathrm{o}}\left(\mathrm{M} 1, \mathrm{M} 3\right.$, and M5) or $\mathrm{G}_{\alpha \mathrm{q}}$ (Eglen, 2005). Binding of ketamine to the $\mathrm{mAChR}$ subtypes M1, M2, and M3 has been described. In particular, assessment of $\left[{ }^{3} \mathrm{H}\right]$ quinuclidinyl benzilate displacement revealed that $(S)$-ketamine has $\sim$ twofold higher affinity than $(R)$-ketamine for $\mathrm{mAChRs}$ (Hustveit et al., 1995). In a subsequent study, Hirota et al. (2002) demonstrated that, with $\mathrm{K}_{\mathrm{i}}$ values of approximately 45 , 294 , and $246 \mu \mathrm{M}$, respectively, ketamine displaced $\left[{ }^{3} \mathrm{H}\right] N$-methyl scopolamine binding to $\mathrm{M} 1, \mathrm{M} 2$, and $\mathrm{M} 3$ mAChRs ectopically expressed in Chinese hamster ovary (CHO) cells. However, the authors reported that ketamine had no significant effect on basal or methacholine-induced $\mathrm{Ca}^{2+}$ signals in M1-expressing CHO cells (Hirota et al., 2002). In contrast, Durieux (1995) reported that, at clinically relevant concentrations, ketamine inhibited M1 mAChR activation in Xenopus oocytes $\left(\mathrm{IC}_{50}=5.7 \mu \mathrm{M}\right)$. The apparently discrepant results could be accounted for by the fact that receptors ectopically expressed in CHO cells and oocytes can have differential sensitivity (e.g., McIntyre et al., 2001). These findings suggest the need for additional studies to identify the exact effects of ketamine on $\mathrm{mAChRs}$ and the functional relevance of these effects.

In contrast to the metabotropic mAChRs, $n A C h R s$ are ionotropic receptors, which are nonselective cation channels activated by the neurotransmitter acetylcholine. These receptors are composed of five subunits. To date, $10 \alpha(\alpha 1-\alpha 10)$ and four $\beta(\beta 1-\beta 4)$ nAChR subunits have been cloned, and different combinations of these subunits give rise to a number of functional $\mathrm{nAChR}$ subtypes, which are expressed in neuronal and nonneuronal cells and have specific pharmacological, functional, and kinetic properties (Albuquerque et al., 2009).

Ketamine is reported to act as a noncompetitive, open-channel blocker of the $\alpha 7, \alpha 4 \beta 2, \alpha 4 \beta 4$, and $\alpha 3 \beta 4$ nAChR subtypes (Flood and Krasowski, 2000; Yamakura et al., 2000; Coates and Flood, 2001; Jozwiak et al., 2002; Pereira et al., 2002). Ketamine concentration dependently blocked acetylcholine (1 $\mathrm{mM})$-induced activation of $\alpha 4 \beta 4 \mathrm{nAChRs}$ ectopically expressed in Xenopus oocytes $\left(\mathrm{IC}_{50}=0.24 \pm 0.03 \mu \mathrm{M}\right)$, with complete inhibition being achieved with $10 \mu \mathrm{M}$ ketamine (Flood and Krasowski, 2000). In addition, with $\mathrm{IC}_{50}$ values of 
20 and $50 \mu \mathrm{M}$, respectively, ketamine inhibited acetylcholine $(1 \mathrm{mM})$-induced activation of $\alpha 7$ and $\alpha 4 \beta 2$ nAChRs ectopically expressed in oocytes (Coates and Flood, 2001). Moreover, Moaddel et al. (2013) showed that ketamine inhibits nicotine-induced $\alpha 3 \beta 4 \mathrm{nAChR}$ activation $\left(\mathrm{IC}_{50}=3.1 \mu \mathrm{M}\right)$. Because ketamine concentrations up to $\sim 10 \mu \mathrm{M}$ are within the clinically relevant range, some nAChR subtypes may underlie the effects of ketamine in vivo.

Moaddel et al. (2013) also demonstrated that at $100 \mathrm{nM}$ $(R, S)$-DHNK reduced the amplitude of acetylcholineinduced whole-cell currents in $\mathrm{KX} \alpha 7 \mathrm{R} 1$ cells that ectopically express $\alpha 7 \mathrm{nAChRs}$ by approximately $60 \%$. At the same concentration, the metabolites $(2 S, 6 S)$ HNK, $(2 R, 6 R)$-HNK, and $(R, S)$-norketamine also reduced the amplitude of acetylcholine-induced $\alpha 7 \mathrm{nAChR}$ currents by approximately 54\%, 51\%, and $45 \%$, respectively (Moaddel et al., 2013). In this study, the authors reported that $(R, S)$-DHNK was not acting as a channel blocker at $\alpha 7 \mathrm{nAChRs}$, because its inhibitory effect was voltage independent. Moreover, $(R, S)$-DHNK did not bind at the agonist-binding site of the $\alpha 7 \mathrm{nAChRs}$, because it did not displace $\alpha$-bungarotoxin binding, suggesting that this metabolite might be acting as a negative allosteric modulator (Moaddel et al., 2013).

The $\alpha 7 \mathrm{nAChR}$ antagonist activity of ketamine metabolites may have implications for the antidepressant action of ketamine. It is noteworthy in this context that blockade of $\alpha 7 \mathrm{nAChRs}$ results in antidepressant effects in rodent models (Mineur and Picciotto, 2010; Philip et al., 2010). Thus, modulation of $\alpha 7 \mathrm{nAChR}$ activity could also be one of the underlying mechanisms involved in ketamine's antidepressant actions, possibly through its metabolites. In support of this hypothesis, nAChR antagonists are aleady in clinical trials for the treatment of depression (Mineur and Picciotto, 2010; Philip et al., 2010).

Other nAChR subtypes are also sensitive to inhibition by therapeutically relevant concentrations of ketamine metabolites. Specifically, in KX $\alpha 3 \beta 4 \mathrm{R} 2$ cells stably expressing rat $\alpha 3 \beta 4 \mathrm{nAChRs}$, ketamine and $(R, S)$ norketamine were reported to inhibit the $\alpha 3 \beta 4 \mathrm{nAChR}$ with $\mathrm{IC}_{50}$ values of approximately 3.1 and $9.1 \mu \mathrm{M}$, respectively, whereas DHNK, $(2 S, 6 S)$-, or $(2 R, 6 R)$-HNK did not have any significant effect on these receptors $\left(\mathrm{IC}_{50}>200 \mu \mathrm{M}\right.$; Moaddel et al., 2013). Therefore, one cannot rule out the possibility that $\alpha 3 \beta 4 \mathrm{nAChRs}$ also contribute to the pharmacological effects of ketamine.

\section{E. Monoaminergic Receptors and Transporters}

Dopamine (DA) and serotonin [5-hydroxytryptamine (5-HT)] receptors are metabotropic receptors, with the exception of the 5-HT receptor subtype 3 , which is ionotropic. Five different subtypes of DA receptors $\left(D_{1-5} R\right)$ and seven subtypes of 5 -HT receptors $\left(5-\mathrm{HT}_{1-7} \mathrm{R}\right)$ have been characterized in the central nervous system (De Felice, 2017). Neurotransmitter transporters regulate DA and 5-HT uptake across the cellular/intracellular membranes and play a key role in the regulation of dopaminergic and serotoninergic neurotransmission.

Although there is some evidence that ketamine may act on DA receptors and transporters (see Table 3), there is also conflicting evidence indicating that ketamine does not directly alter dopaminergic signaling; also see Kokkinou et al. (2018). Ketamine was reported to have high affinity $(0.06-1.0 \mu \mathrm{M})$ for $\mathrm{D}_{2}$ receptors $\left(\mathrm{D}_{2} \mathrm{Rs}\right.$; Kapur and Seeman, 2002; Seeman et al., 2005) and to act as a partial agonist at these receptors $\left(\mathrm{EC}_{50}=\right.$ $0.9 \pm 0.4 \mu \mathrm{M})$. This partial agonist activity at $\mathrm{D}_{2} \mathrm{Rs}$ was suggested to contribute to the psychotomimetic effects of ketamine (Kapur and Seeman, 2002; Seeman et al., 2005). This is further supported by the finding that a ketamine-induced decrease in $\mathrm{D}_{2} \mathrm{R}$ binding is significantly correlated with schizophrenia-related symptoms in humans, as measured by PET scanning (Breier et al., 1998).

There are several published studies reporting ketamine-induced decreases in striatal $\mathrm{D}_{2} \mathrm{R}$ binding (an indirect measure of DA release) in humans. Specifically, subanesthetic doses of ketamine (i.v. bolus of ketamine; $0.12 \mathrm{mg} / \mathrm{kg}$ ), followed by an i.v. infusion of $0.65 \mathrm{mg} / \mathrm{kg}$ ketamine over 60 minutes $(0.29-0.45 \mu \mathrm{M}$; Breier et al., 1998), $0.5 \mathrm{mg} / \mathrm{kg}$ ketamine over 20 minutes (Smith et al., 1998 ), or $0.014 \mathrm{mg} / \mathrm{kg}$ per minute $(S)$-ketamine for 90 minutes (Vollenweider et al., 2000) decreased striatal $\mathrm{D}_{2} \mathrm{R}$ binding. However, subsequent studies have failed to replicate these findings using single-photon emission computed tomography/PET techniques. In particular, when ketamine was administered as an i.v. bolus $(0.12 \mathrm{mg} / \mathrm{kg})$ followed by a constant 70 -minute i.v. infusion $(0.65 \mathrm{mg} / \mathrm{kg}$ per hour), resulting in an average plasma concentration of $0.59 \pm 0.22 \mu \mathrm{M}$ in healthy individuals, there was no change in $\mathrm{D}_{2} \mathrm{R}$ availability in striatal regions of the brain (Kegeles et al., 2002). Similarly, i.v. infusion of ketamine (66-minute infusion yielding a stable plasma ketamine concentration of $1.23 \pm 0.12 \mu \mathrm{M})$ in healthy male volunteers did not alter striatal $\mathrm{D}_{2} \mathrm{R}$ binding (Aalto et al., 2002). In accordance with the lack of direct effects of subanesthetic doses of ketamine on the dopamine $\mathrm{D}_{2} \mathrm{R}$, psychotomimetic effects of a $0.23 \mathrm{mg} / \mathrm{kg}$ bolus or $0.65 \mathrm{mg} / \mathrm{kg}$ per hour infusion of ketamine were not blocked by administration of a $\mathrm{D}_{2} \mathrm{R}$ antagonist in humans (Krystal and D'Souza, 2001). In addition, ketamine was not found to modify electrically evoked accumbal DA release measured in real-time using fast-scan cyclic voltammetry in mice (Can et al., 2016). In contrast to the previously mentioned studies, it was also reported that ketamine lacks functional agonist and antagonist activity on all of the DA receptor subtypes at concentrations up to $10 \mu \mathrm{M}$ (Can et al., 2016).

Inhibition of the DA transporter by ketamine in HEK293 cells has also been reported $\left(\mathrm{K}_{\mathrm{i}}=62.9 \mu \mathrm{M}\right.$; Nishimura et al., 1998). However, this effect did not occur at concentrations up to $10 \mu \mathrm{M}$ (Can et al., 2016). 
Because this effect was only observed at relatively high concentrations, its functional/clinical relevance remains to be determined.

Ketamine was also reported to bind to $5-\mathrm{HT}_{2}$ receptors with an affinity of $15 \pm 5 \mu \mathrm{M}$ (Kapur and Seeman, 2002). This finding might be relevant to the analgesic effects of the drug, because the $5-\mathrm{HT}_{2 \mathrm{~B} / 2 \mathrm{C}}$ receptor antagonist methysergide inhibited the analgesic effects of ketamine in rats (Crisp et al., 1991), implicating serotonergic signaling in the mechanisms of ketamine analgesia. Moreover, ketamine administration induced an increase in extracellular serotonin (5-HT) levels in the prefrontal cortex and dorsal raphe nucleus of mice (Pham et al., 2017b).

In nonhuman primates, ketamine administration was shown to significantly increase accumbal and ventral pallidum $5-\mathrm{HT}_{1 \mathrm{~B}}$ receptor binding, an effect that was blocked by pretreatment with the $\alpha$-amino-3hydroxy-5-methyl-4-isoxazolepropionic acid (AMPA) receptor antagonist 2,3-dihydroxy-6-nitro-7-sulfamoylbenzo[f]quinoxaline-2,3-dione (NBQX; Yamanaka et al., 2014). This finding may suggest that this effect of ketamine is involved in its antidepressant actions because AMPA receptor activation is a convergent mechanism of ketamine's antidepressant actions, and NBQX administration abolishes ketamine's effects in several animal tests of antidepressant efficacy (Maeng et al., 2008; Autry et al., 2011; Koike et al., 2011; Walker et al., 2013; Fukumoto et al., 2014; Koike and Chaki, 2014; Zhou et al., 2014; Yang et al., 2015; Zanos et al., 2016; Zanos et al., 2018b,c). Antagonist actions of ketamine on $5-\mathrm{HT}_{3}$ receptors have been reported, but these occur at higher than clinically relevant concentrations $\left(\mathrm{Ki}>90 \mu \mathrm{M} ; \mathrm{IC}_{50}>100 \mu \mathrm{M}\right.$; Appadu and Lambert, 1996; Yamakura et al., 2000; Ho and Flood, 2004).

Several studies suggest that increased 5-HT levels are necessary for the antidepressant-like effects of ketamine in rodents. For instance, pharmacological treatments that reduce 5-HT levels in the brain abolished ketamine's antidepressant behavioral effects in the forced-swim test (du Jardin et al., 2016; Pham et al., $2017 \mathrm{~b}$ ) and in the novelty-suppressed feeding test (Fukumoto et al., 2014) in rodents. In addition, higher extracellular 5-HT levels were positively correlated with ketamine's antidepressant activity in the forcedswim test in mice (Pham et al., 2017b). Whether these effects are due to a direct action of ketamine on 5-HT receptors is not clear and needs further investigation. Nevertheless, there are also conflicting data on the effects of ketamine on 5-HT receptors, because even at very high concentrations $(1 \mathrm{mM})$ ketamine only slightly altered $\left[{ }^{3} \mathrm{H}\right] 5$-HT or $\left[{ }^{3} \mathrm{H}\right]$ spiroperidol binding to 5 - $\mathrm{HT}_{1}$ or $5-\mathrm{HT}_{2}$ receptors, respectively (Martin et al., 1982). It is thus possible that ketamine may interact with serotonin uptake as opposed to directly binding to serotonin receptors. Indeed, administration of antidepressant doses of ketamine ( $1.5 \mathrm{mg} / \mathrm{kg}$; 40-minute infusion) to nonhuman primates reduced serotonin transporter (SERT) activity (Yamamoto et al., 2013), an effect that was hypothesized to reflect direct binding of ketamine to SERTs to regulate 5-HT reuptake. However, in vitro work indicated that ketamine inhibits SERTs at concentrations ranging from 75 (Azzaro and Smith, 1977) to $162 \mu \mathrm{M}$ (Nishimura et al., 1998), which are not only above the antidepressant-relevant concentrations, but also well above the clinical anesthetic concentrations of ketamine. At antidepressant-relevant concentrations, ketamine does not have an agonist or antagonist effect on SERTs (Can et al., 2016). Therefore, in vivo evidence of ketamine-induced inhibition of serotonin reuptake (Martin et al., 1982) could be attributed to indirect interactions of ketamine with the serotonergic system, at least at subanesthetic concentrations.

Finally, although there is some evidence that ketamine acts as an uptake inhibitor at norepinephrine transporters (NETs; $\mathrm{K}_{\mathrm{i}}=66.8 \mu \mathrm{M}$; Nishimura et al., 1998), the inhibition constant indicates that ketamine would not modulate NET function at clinically relevant concentrations (up to $10 \mu \mathrm{M}$ ). There is also a noted lack of functional activity of clinically relevant concentrations of ketamine (up to $10 \mu \mathrm{M}$ ) on NETs (Can et al., 2016).

To date, there is only one published study assessing the effect of ketamine's metabolites on monoaminergic receptors and transporters. At concentrations up to $10 \mu \mathrm{M}$ there was no agonist or antagonist activity of $(S)$-norketamine, $(R)$-norketamine, $(S)$-dehydronorketamine, $(R)$-dehydronorketamine, $(2 S, 6 S)$-HNK, or $(2 R, 6 R)$-HNK on $\mathrm{D}_{1}, \mathrm{D}_{2}, \mathrm{D}_{3}, \mathrm{D}_{4}$, or $\mathrm{D}_{5}$ receptors; DA transporter; NET; or SERT (Can et al., 2016). Although these findings suggest that direct effects of ketamine metabolites on DA receptors or monoaminergic transporters do not account for the antidepressant actions of ketamine, it cannot be ruled out that, at higher concentrations, ketamine's metabolites may interact with and directly or indirectly modify the activity of these receptors and transporters.

\section{F. Opioid Receptors}

Opioid receptors are expressed throughout the central nervous system as well as in peripheral tissues (Trescot et al., 2008). These receptors are G proteincoupled receptors and are classified into three subtypes ( $\mu$-, $\delta$-, and $\kappa$-opioid receptors) (Kieffer and GaveriauxRuff, 2002). A primary function of opioid receptor activation is inhibiting the transmission of nociceptive stimuli, resulting in analgesia (Trescot et al., 2008; Stein, 2016).

Ketamine was reported to activate human recombinant $\mu-, \kappa$-, and $\delta$-opioid receptors expressed in CHO cells $\left(\mathrm{K}_{\mathrm{i}}=42.1,28.1\right.$, and $272 \mu \mathrm{M}$, respectively; Hirota et al., 1999). ( $S$ )-ketamine was shown to have higher affinity compared with $(R)$-ketamine for binding to opioid receptors. In particular, $(S)$-ketamine's affinities 
range from 11 to $29 \mu \mathrm{M}$ for the $\mu-, 25-28 \mu \mathrm{M}$ for the $\kappa^{-}$, and $130-205 \mu \mathrm{M}$ for the $\delta$-opioid receptors (Hustveit et al., 1995; Hirota et al., 1999; Nemeth et al., 2010). In contrast, $(R)$-ketamine has affinities ranging from 28 to $84 \mu \mathrm{M}$ for the $\mu-, 60-100 \mu \mathrm{M}$ for the $\kappa-$, and $130-286 \mu \mathrm{M}$ for the $\delta$-opioid receptors (Hustveit et al., 1995; Hirota et al., 1999). Similar to these findings, $(S)$-ketamine $\left(\mathrm{IC}_{50}=23.0 \pm 1.2 \mu \mathrm{M}\right)$ showed higher potency to bind and displace the non-specific opioid ligand $\left[{ }^{3} \mathrm{H}\right]$ dihydromorphine compared with the racemic ketamine $\left(\mathrm{IC}_{50}=\right.$ $16.3 \pm 7.4 \mu \mathrm{M})$ and $(R)$-ketamine $\left(\mathrm{IC}_{50}=45.5 \pm 3.2 \mu \mathrm{M}\right.$; Finck and Ngai, 1982).

The actions of ketamine at opioid receptors are hypothesized to be involved in its analgesic effects (Finck et al., 1988; Pacheco Dda et al., 2014), and these findings are consistent with the higher potency of $(S)$-ketamine in measures of antinociception compared with $(R$ )-ketamine (White et al., 1980; Oye et al., 1992; Mathisen et al., 1995). However, the exact roles of opioid receptors in mediating these effects are unclear.

Although the analgesic actions of ketamine are blocked by intracerebroventricular administration (i.e., direct brain exposure) of $\mu$ - and $\delta$-, but not $\kappa$-opioid receptor antagonists in mice (Pacheco Dda et al., 2014), global opioid receptor inhibition achieved by systemic administration of naloxone does not prevent ketamineinduced analgesia in humans (Mikkelsen et al., 1999). These seemingly opposing findings indicate that ketamine might induce analgesia via an indirect interaction with the opioid system, or may exert an opioid receptor subtype-specific action. In support of such a subtype-specific effect, in vivo evidence indicates that ketamine might be a $\kappa$-opioid receptor agonist and a $\mu$-opioid receptor antagonist. Specifically, ketamine microinjection in the periaqueductal gray region, which contains $\mu$-but not $\kappa$-opioid receptors, did not exert antinociceptive effects, but blocked the effects of the $\mu$-opioid receptor agonist, morphine, in the same region (Smith et al., 1985). This could explain the failure of naloxone to block ketamine-induced analgesia and supports a subtype-specific role of opioid receptors in ketamine-induced analgesia. However, it should be noted that these findings are in opposition of the results of Pacheco Dda et al. (2014), as discussed above. Furthermore, it has been reported that subeffective doses of ketamine only partially antagonize the cataleptic actions of morphine in rats (Hance et al., 1989); however, a combination of subeffective doses of ketamine and morphine induced catalepsy in the same experimental settings (Hance et al., 1989). Altogether, these findings implicate the opioid system in ketamine's analgesic effects, but further studies are needed to clarify the exact mechanisms. Interactions between ketamine and the opioid system may be more relevant in chronic pain, in which ketamine reduces opioid tolerance. In particular, via acting on the downstream extracellular signal-regulated kinase
1/2 pathway, ketamine $(10 \mu \mathrm{M})$ abolished $\mu$-opioid receptor-induced desensitization in vitro (Gupta et al., 2011).

Activation of $\kappa$-opioid receptors by ketamine $\left(\mathrm{EC}_{50}=\right.$ $29 \mu \mathrm{M}$ ) was reported to be involved in ketamine's effects on attention and visual perception in rats assessed in the five-choice serial reaction time task (Nemeth et al., 2010). Pretreatment with a selective $\kappa$-opioid receptor antagonist blocked the ability of ketamine $(20 \mathrm{mg} / \mathrm{kg})$ to impair attention and visual perception (Nemeth et al., 2010). In contrast, in healthy volunteers, inhibition of opioid receptors by naloxone augmented the dissociative and cognitive deficit effects induced by a subthreshold administration of ketamine (1-minute $0.23 \mathrm{mg} / \mathrm{kg}$ bolus, followed by a 60 -minute $0.58 \mathrm{mg} / \mathrm{kg}$ ketamine infusion; Krystal et al., 2006), possibly indicating an antagonist activity of low doses of ketamine on the opioid receptors in vivo. Nevertheless, further work is needed to establish the exact role of opioid receptor modulation in mediating the side effects of ketamine. There are currently no published studies assessing the effects of ketamine's metabolites on opioid receptors. However, there is recent evidence indicating that $(2 R, 6 R ; 2 S, 6 S)-\mathrm{HNK}$ (at $10 \mathrm{and} / \mathrm{or} 30 \mathrm{mg} / \mathrm{kg}$, s.c.) does not possess antinociceptive properties and does not alter opioid (morphine) tolerance in rats (Lilius et al., 2018a), indicating a possible lack of interactions between this metabolite and the opioid receptor system. Notably, norketamine, similar to ketamine, attenuates tolerance to morphine (Lilius et al., 2018b).

\section{G. Sigma Receptors}

Another potential site of action of ketamine is the sigma receptor. Sigma receptors are classified into two different subtypes, sigma I and II receptors $\left(\sigma_{1} R\right.$ and $\sigma_{2} R$, respectively; Bowen et al., 1989). Although a third subtype has also been suggested to exist $\left(\sigma_{3} R\right)$, it has not been fully defined (Myers et al., 1994).

As illustrated in Table 3, ketamine binding has been described at both $\sigma 1 \mathrm{R}$ and $\sigma 2 \mathrm{R}$ (Smith et al., 1987; Hustveit et al., 1995; Robson et al., 2012). The first evidence of direct binding of ketamine to sigma receptors came from Klepstad et al. (1990), who demonstrated that $(R)$-ketamine has a potency of $\mathrm{IC}_{50}=\sim 15 \mu \mathrm{M}$ to bind to sigma receptors, whereas $(S)$-ketamine has an $\mathrm{IC}_{50}$ of $\sim 100 \mu \mathrm{M}$. Although these findings were qualitative and not absolutely quantitative due to the different brain regions used for the binding studies, Hustveit et al. (1995) confirmed these initial findings by showing that $(R)$-ketamine has an affinity of $19 \mu \mathrm{M}$ at sigma receptors, whereas (S)-ketamine shows $\sim 15$-fold lower binding affinity for these receptors $(131 \mu \mathrm{M})$. Robson et al. (2012) reported that $(R, S)$-ketamine has a preferential affinity for the $\sigma_{2} \mathrm{R}\left(\mathrm{K}_{\mathrm{i}}=26.3 \mu \mathrm{M}\right)$ compared with the $\sigma_{1} \mathrm{R}\left(\mathrm{K}_{\mathrm{i}}=139.6 \mu \mathrm{M}\right)$. In support of such binding in vivo, studies in nonhuman primates showed competition binding between ketamine and $\left[{ }^{11} \mathrm{C}\right] \mathrm{SA} 5845$, a sigma receptor PET tracer (Kortekaas et al., 2008). 
Sigma receptors are promising targets for antidepressant treatment (Fishback et al., 2010), and activation of these receptors induces antidepressant behavioral responses in animals (Matsuno et al., 1996; Skuza and Rogoz, 2002; Wang et al., 2007; Lucas et al., 2008) and humans (Pande et al., 1999). As a result it could be postulated that the action of ketamine on sigma receptors is involved in the mechanisms underlying its antidepressant responses, consistent with $(R)$-ketamine's higher binding affinity for these receptors, and its more potent antidepressant effects compared with $(S)$-ketamine in rodent models (Zhang et al., 2014; Yang et al., 2015; Zanos et al., 2016; Fukumoto et al., 2017).

Although administration of $\sigma_{1} \mathrm{R}$ and $\sigma_{2} \mathrm{R}$ antagonists did not attenuate the antidepressant behavioral effects of ketamine in mice (Robson et al., 2012), administration of a $\sigma_{1} R$-selective antagonist blocked the potentiating effects of ketamine on nerve growth factor-induced neurite outgrowth, and thus, modulation of neuroplasticityrelated pathways (Robson et al., 2012) that are involved in the antidepressant effects of the drug (see Kavalali and Monteggia (2012), Gerhard et al. (2016)). These findings may indicate that ketamine's actions on sigma receptors could be involved in the neuroplasticity-related effects of the drug, and thus indirectly involved in its antidepressant actions. There is currently no evidence of activity of ketamine's metabolites on sigma receptors.

\section{H. Voltage-Gated Sodium Channels}

Voltage-gated ion channels are among the first identified ion channels and are involved in the generation of action potentials (Hodgkin and Huxley, 1952). Local anesthetics typically induce concentration-dependent inhibition of sodium channel activity, via binding to sites within the channel pore (Becker and Reed, 2012). Whereas ketamine has been shown to act as a local anesthetic in veterinary practice and in human patients (Bion, 1984; Gomez de Segura et al., 1998; Hawksworth and Serpell, 1998; Kathirvel et al., 2000), there is currently conflicting evidence regarding the effects of ketamine on voltagegated sodium channel activity.

In isolated guinea pig ventricular myocytes, ketamine at concentrations ranging from 30 to $300 \mu \mathrm{M}$ induced a concentration-, but not use-dependent tonic inhibition of sodium channel currents (16\%-36\% inhibition; Hara et al., 1998b). In contrast, both tonic $\left(\mathrm{IC}_{50}=866.2 \pm\right.$ $34.7 \mu \mathrm{M})$ and phasic $\left(\mathrm{IC}_{50}=314.8 \mu \mathrm{M}\right)$ blockade of sodium channels was induced by ketamine in rat dorsal root ganglion neurons (Zhou and Zhao, 2000). In addition, ketamine was reported to block voltage-gated sodium channels in Xenopus oocytes (tonic inhibition: $\mathrm{IC}_{50}=$ $800 \mu \mathrm{M}$; phasic inhibition: $\mathrm{IC}_{50}=2.3 \mathrm{mM}$; Wagner et al., 2001). Moreover, although Benoit (1995) demonstrated no inhibitory effect of ketamine on nodal sodium- channel currents of myelinated nerve fibers, others have reported up to $71.1 \%$ blockade of sodium channel conductance by ketamine $\left(\mathrm{ED}_{50}=1.1 \mathrm{mM}\right.$; Frenkel and Urban, 1992). A study assessing the effects of $(S)$ and $(R)$-ketamine on the activity of sodium channels showed that $(S)$-ketamine inhibits voltage-gated sodium channels with an apparent potency of $240 \pm$ 60 and $59 \pm 10 \mu \mathrm{M}$ in neuronal and skeletal muscle isoforms, respectively. The potency of $(R)$-ketamine to block sodium channels was lower $\left(\mathrm{IC}_{50}=333 \pm 93\right.$ and $181 \pm 49 \mu \mathrm{M}$ in neuronal and skeletal muscle isoforms, respectively; Haeseler et al., 2003) than that of $(S)$ ketamine. Similarly, Schnoebel et al. (2005) showed stereoselective tonic block of voltage-gated sodium currents with $(S)$-ketamine being more potent than $(R)$-ketamine $\left(\mathrm{IC}_{50}=128\right.$ and $269 \mu \mathrm{M}$, respectively). These findings predict that $(S)$-ketamine is a more effective local anesthetic than $(R)$-ketamine.

These discrepancies in the effects of ketamine on the activity of sodium channels might be due to differences in the cell populations and experimental procedures used. Overall, these findings support an inhibitory effect of ketamine on sodium channels, which is a characteristic of local anesthetics (Becker and Reed, 2012). These effects occur at concentrations well above circulating ketamine levels relevant for general anesthesia, but could possibly be relevant to local ketamine anesthesia.

\section{L-Type Voltage-Dependent Calcium Channels}

The L-type voltage-dependent calcium channel (VDCC) family consists of four different members referred to as $\mathrm{Ca}_{\mathrm{v}} 1.1-\mathrm{Ca}_{\mathrm{v}} 1.4$ (Catterall, 2011). $\mathrm{Ca}_{\mathrm{v}} 1.2$ is the main LTCC expressed in the mammalian brain (Bhat et al., 2012). Antagonism of L-type VDCCs by ketamine has been reported over a wide range of concentrations. In porcine tracheal smooth muscle cells, for example, ketamine blocked VDCCs with an $\mathrm{IC}_{50}$ of $1 \mathrm{mM}$ (Yamakage et al., 1995). In rabbit portal vein smooth cells, $1 \mathrm{mM}$ ketamine completely inhibited VDCC currents (Yamazaki et al., 1992). Finally, in bullfrog single atrial cells, ketamine inhibited VDCC currents with an $\mathrm{IC}_{50}$ of $9.2 \mu \mathrm{M}$ (Hatakeyama et al., 2001). This effect was not use-dependent, and ketamine did not act as an open channel blocker. Nonusedependent tonic inhibition of VDCCs was also reported in isolated guinea pig ventricular myocytes, in which 30-300 $\mu \mathrm{M}$ induced a 26\%-53\% inhibition (Hara et al., 1998b). The discrepancies in the reported concentrations at which ketamine inhibits VDCCs may be due to differences in species, cell type, or experimental preparations (e.g., differences in bath solutions).

Despite evidence of VDCC inhibition by ketamine, an in vitro study showed that AMPA receptor activation and subsequent increases in brain-derived neurotrophic factor release and mechanistic target of rapamycin complex 1 activation-actions that are believed to underlie ketamine's antidepressant properties-require VDCC activation (Jourdi et al., 2009). Furthermore, ketamine's antidepressant effects in mice are blocked by 
pretreatment with L-type calcium channel antagonists (Lepack et al., 2014). These findings are not in line with the inhibitory activity of ketamine at these channels, as previously described. However, it should be noted that these studies were performed in cells derived from peripheral tissues (e.g., heart, trachea) and that effects of ketamine on VDCCs in brain-derived cells at antidepressant-relevant concentrations have not been reported to our knowledge. In addition to the possible role of ketamine-induced inhibition of calcium channels in mediating the antidepressant actions of the drug, blockade of calcium channels has been also hypothesized to be involved in the psychoactive/psychotomimetic effects of ketamine (Lisek et al., 2016).

\section{Conclusions}

Ketamine has been in clinical use as an anesthetic since the 1970s. However, novel use indications (e.g., chronic pain and depression) and mechanisms of action (e.g., HNK metabolites) are still emerging. Its use as an anesthetic, analgesic, anti-inflammatory, and antidepressant drug has reignited research to understand the neurobiological mechanisms underlying these effects of ketamine, as well as its metabolites, and several molecular and cellular targets have been identified to date.

Ketamine is typically used clinically (and in preclinical research) as the racemic mixture, $(R-S)$-ketamine. It is extensively and rapidly metabolized in vivo, resulting in the formation of norketamine and HKs, followed by production of the secondary metabolites, DHNK and the HNKs. Although ketamine, norketamine, and HNKs readily cross the blood-brain barrier, DHNK does not appear to reach pharmacologically active brain concentrations, at least in the mouse brain (Can et al., 2016). Ketamine, and to a lesser extent, norketamine, are noncompetitive antagonists of the NMDAR ion channel. DHNK and HNKs, however, appear to have much lower potency to inhibit the NMDAR, if at all (Morris et al., 2017; Suzuki et al., 2017; Zanos et al., 2017a).

In addition to the NMDAR, we reviewed findings supporting ketamine's actions at a number of receptors and ion channels, including DA, 5-HT, opioid, cholinergic, sigma, and $\mathrm{GABA}_{\mathrm{A}}$ receptors, as well as monoamine transporters and HCN, sodium, and L-type VDCCs. Ketamine's well-characterized anesthetic effects are primarily attributed to NMDAR inhibition. However, there is evidence that HCN channel inhibition might also be involved in the anesthetic properties of ketamine. Similarly, evidence implicates NMDAR inhibition in the analgesic actions of ketamine, with the possibility of opioid receptors also playing a role.

\section{A. (R)- and (S)-Ketamine as Antidepressants}

Much attention has focused upon the NMDAR as the primary pharmacological target responsible for ketamine's antidepressant actions. However, in contrast to this prediction, clinical studies have suggested no-or only modest-antidepressant efficacy of some alternative NMDAR antagonists. To date, these drugs lack the robust, rapid, or sustained antidepressant effectiveness of ketamine, and some (e.g., memantine) have been proven clinically ineffective in multiple studies (Newport et al., 2015). Moreover, Hashimoto and colleagues first reported superior and longer-lasting antidepressant actions of $(R)$-ketamine compared with $(S)$-ketamine in rodent models (Zhang et al., 2014; Yang et al., 2015; Fukumoto et al., 2017). These findings were also supported by Zanos et al. (2016), who showed that (S)-ketamine's antidepressant behavioral effects only become apparent at higher doses compared with $(R)$-ketamine. The increased potency of $(R)$-ketamine does not seem to be related to a U-shaped dose response of the drugs, as it has been shown more potent compared with $(S)$-ketamine with up to a 30 -fold range of doses in multiple mouse tests of antidepressant efficacy (Zanos et al., 2016; Fukumoto et al., 2017). Administration of equal doses of $(R)$ - and $(S)$-ketamine did not yield different levels of these enantiomers in the brains of rodents (Zanos et al., 2016; Fukumoto et al., 2017), indicating that increased antidepressant potency of $(R)$-ketamine in rodent models is not due to greater brain levels of the drug. These preclinical rodent data indicate that $(R)$-ketamine is a more potent antidepressant compared with the $(S)$-ketamine enantiomer (Zhang et al., 2014; Yang et al., 2015; Zanos et al., 2016; Fukumoto et al., 2017), suggesting that it is unlikely that ketamine exerts its antidepressant actions solely via inhibition of the NMDAR (Zanos et al., 2018a). Nevertheless, we note that preclinical rodent studies have also indicated rapid-acting antidepressant behavioral actions of $(S)$-ketamine in mice (Zhang et al., 2014; Yang et al., 2015; Zanos et al., 2016; Fukumoto et al., 2017).

The finding that ketamine exerts rapid antidepressant actions, within hours of administration, has focused extensive research efforts on understanding this phenomenon. This finding and elucidation of the relevant mechanisms involved have the potential to revolutionize the treatment of depression, considering that currently approved antidepressants take weeks or even months to exert their full antidepressant effects (Rush et al., 2006), and many patients suffering from major depressive disorders are resistant to classic antidepressant pharmacotherapies. Similar to racemic ketamine, clinical human studies in depressed patients have indicated that a 40-minute, i.v. infusion of $(S)$-ketamine exerts rapid antidepressant actions (within 2 hours of administration; Singh et al., 2016a). In addition, there are reported dose-dependent antidepressant actions of intranasally administered $(S)$-ketamine (dose of 28-84 mg, twice per week for a total of 2 weeks) in treatment-resistant depressed patients under oral classic antidepressant treatment (Daly et al., 2018). $(S)$-ketamine is currently in phase III clinical trials as an antidepressant (Andrade, 2017a). 
If in human depression, as is the case in mouse models, $(R)$-ketamine has superior potency to $(S)$-ketamine, this would have advantages considering its fewer side effects due to less potent inhibition of the NMDAR (see section $N$-Methyl-D-Aspartate Receptors). However, there are currently no published clinical studies assessing the antidepressant efficacy of $(R)$-ketamine in depressed patients. Furthermore, there are no published clinical studies directly comparing the antidepressant actions of the $(S)$ - and $(R)$-ketamine enantiomers, or comparing the actions of either enantiomer to the racemic mixture.

\section{B. Utility of Ketamine's Hydroxynorketamine Metabolites as Drug Treatments}

It was reported that metabolism of ketamine is necessary for its full antidepressant actions in mice (Zanos et al., 2016). Specific HNK metabolites of ketamine, $(2 S, 6 S)$-HNK, and $(2 R, 6 R)$-HNK, derived from the metabolism of $(S)$-ketamine and $(R)$-ketamine, respectively, do not bind to or functionally inhibit the NMDAR at antidepressant-relevant concentrations (Morris et al., 2017; Suzuki et al., 2017; Zanos et al., 2017a), but do exert antidepressant behavioral effects similar to those observed following administration of ketamine itself (Zanos et al., 2016). These findings further challenge the NMDAR inhibition hypothesis of ketamine's antidepressant actions. In addition, $(2 R, 6 R)$-HNK exerts antidepressant effects without the sensory dissociation, ataxia, and abuse liability of ketamine in animal tests (Zanos et al., 2016). Indeed, the psychoactive side effects of ketamine, including dissociation and changes in sensory perception, as well as its abuse potential, have been attributed to the NMDARinhibition effects of ketamine (Shaffer et al., 2014).

The recent findings that ketamine metabolites are involved in the antidepressant actions of ketamine suggest the possible use of these metabolites in the treatment of depression and open new paths for investigating their role in other brain disorders. As we discussed earlier, HNK metabolites may contribute to the clinical effects of subanesthetic doses of ketamine, perhaps due to their direct actions on nAChRs (Moaddel et al., 2013), indirect actions on D-serine (Singh et al., $2013,2016 \mathrm{c}$ ), or other targets that have not yet been identified. This work may provide a framework for a novel ketamine metabolite paradigm, which posits clinically relevant effects dependent upon metabolic conversion of ketamine, but it does not involve NMDAR inhibition (Singh et al., 2014). Nevertheless, future preclinical studies are needed to support the contention that NMDAR inhibition is not required for the effectiveness of ketamine's metabolites as fast-acting antidepressants and to identify the underlying mechanism of action of these metabolites. It also remains to be investigated whether ketamine metabolites have a role in the anti-inflammatory or analgesic actions of ketamine.

\section{Future Directions}

Identification of the targets responsible for the different behavioral effects of ketamine, and potentially its metabolites, is critical for the development of novel pharmacotherapies that will lack the side effects of ketamine, including psychotomimetic effects, changes in sensory perception, and abuse potential. In addition to the recently completed studies in preclinical depression models (Zanos et al., 2016), studies of ketamine metabolites in animal models of pain, inflammation, depression, and suicidality (see Gould et al., 2017) are essential to better understand their therapeutic potential. Expanded clinical use of racemic ketamine, $(S)$-ketamine, $(R)$-ketamine, and potentially key metabolites [i.e., $(2 R, 6 R)-\mathrm{HNK}$ ] represents an important opportunity to define new therapies for unmet medical conditions and to better define pharmacology-phenotype relationships. Notably, clinical exploration of these agents is feasible given the historical safety knowledge surrounding racemic and enantio-pure forms of ketamine (and thus its metabolites) when given acutely. As such, investments in alternate routes of administration, dosing strategies, and drug combination assessments are not overly burdensome. Furthermore, the breadth of potential indications coupled to ketamine's multiple pharmacological targets offers an unprecedented window of insight into new mechanisms for future therapeutic interventions. Given these factors, it is clear that the comprehensive understanding of ketamine and ketamine metabolite pharmacology presents invaluable opportunities in both basic and translational research and clinical care.

\section{Authorship Contributions}

Wrote or contributed to the writing of the manuscript: Zanos, Moaddel, Morris, Riggs, Highland, Georgiou, Pereira, Albuquerque, Thomas, Zarate, Gould.

\section{References}

Aalto S, Hirvonen J, Kajander J, Scheinin H, Någren K, Vilkman H, Gustafsson L, Syvälahti E, and Hietala J (2002) Ketamine does not decrease striatal dopamine D2 receptor binding in man. Psychopharmacology (Berl) 164:401-406.

Abel KM, Allin MP, Hemsley DR, and Geyer MA (2003) Low dose ketamine increases prepulse inhibition in healthy men. Neuropharmacology 44:729-737.

Adamowicz P and Kala M (2005) Urinary excretion rates of ketamine and norketamine following therapeutic ketamine administration: method and detection window considerations. J Anal Toxicol 29:376-382.

Adams JD Jr, Baillie TA, Trevor AJ, and Castagnoli N Jr (1981) Studies on the biotransformation of ketamine: 1-Identification of metabolites produced in vitro from rat liver microsomal preparations. Biomed Mass Spectrom 8:527-538.

Adams JD, Castagnoli N, and Trevor AJ (1978) Quantitative analysis of ketamine enantiomers. Proc West Pharmacol Soc 21:471-472.

Akin A, Esmaoglu A, Guler G, Demircioglu R, Narin N, and Boyaci A (2005) Propofol and propofol-ketamine in pediatric patients undergoing cardiac catheterization. Pediatr Cardiol 26:553-557.

Albuquerque EX, Pereira EF, Alkondon M, and Rogers SW (2009) Mammalian nicotinic acetylcholine receptors: from structure to function. Physiol Rev 89:73-120.

Allaoua H and Chicheportiche R (1989) Anaesthetic properties of phencyclidine (PCP) and analogues may be related to their interaction with $\mathrm{Na}+$ channels. Eur $J$ Pharmacol 163:327-335.

Allen HL and Iversen LL (1990) Phencyclidine, dizocilpine, and cerebrocortical neurons. Science 247:221.

Anand A, Charney DS, Oren DA, Berman RM, Hu XS, Cappiello A, and Krystal JH (2000) Attenuation of the neuropsychiatric effects of ketamine with lamotrigine: support for hyperglutamatergic effects of N-methyl-D-aspartate receptor antagonists. Arch Gen Psychiatry 57:270-276.

Andrade C (2017a) Ketamine for depression, 3: does chirality matter? J Clin Psychiatry 78:e674-e677. 
Andrade C (2017b) Ketamine for depression, 4: in what dose, at what rate, by what route, for how long, and at what frequency? $J$ Clin Psychiatry 78: e852-e857.

Anis NA, Berry SC, Burton NR, and Lodge D (1983) The dissociative anaesthetics, ketamine and phencyclidine, selectively reduce excitation of central mammalian neurones by N-methyl-aspartate. Br J Pharmacol 79:565-575.

Appadu BL and Lambert DG (1996) Interaction of i.v. anaesthetic agents with 5-HT3 receptors. $\mathrm{Br}$ J Anaesth 76:271-273.

Arditti J, Spadari M, de Haro L, Brun A, Bourdon JH, and Valli M (2002). Ketaminedreams and realities. Acta Clin Belg 57 (Suppl 1):31-33.

Arias HR, McCardy EA, Bayer EZ, Gallagher MJ, and Blanton MP (2002) Allosterically linked noncompetitive antagonist binding sites in the resting nicotinic acetylcholine receptor ion channel. Arch Biochem Biophys 403:121-131.

Auer RN (1996) Effect of age and sex on N-methyl-D-aspartate antagonist-induced neuronal necrosis in rats. Stroke 27:743-746.

Augustinack JC, Schneider A, Mandelkow EM, and Hyman BT (2002) Specific tau phosphorylation sites correlate with severity of neuronal cytopathology in Alzheimer's disease. Acta Neuropathol 103:26-35.

Autry AE, Adachi M, Nosyreva E, Na ES, Los MF, Cheng PF, Kavalali ET, and Monteggia LM (2011) NMDA receptor blockade at rest triggers rapid behavioural antidepressant responses. Nature 475:91-95.

Azevedo VM, Lauretti GR, Pereira NL, and Reis MP (2000) Transdermal ketamine as an adjuvant for postoperative analgesia after abdominal gynecological surgery using lidocaine epidural blockade. Anesth Analg 91:1479-1482.

Azzaro AJ and Smith DJ (1977) The inhibitory action of ketamine HC1 on [3H]5hydroxytryptamine accumulation by rat brain synaptosomal-rich fractions: comparison with $[3 \mathrm{H}]$ catecholamine and $[3 \mathrm{H}] \gamma$-aminobutyric acid uptake. Neuropharmacology 16:349-356.

Backonja M, Arndt G, Gombar KA, Check B, and Zimmermann M (1994) Response of chronic neuropathic pain syndromes to ketamine: a preliminary study. Pain 56: $51-57$

Ballard ED, Ionescu DF, Vande Voort JL, Niciu MJ, Richards EM, Luckenbaugh DA Brutsché NE, Ameli R, Furey ML, and Zarate CA Jr (2014) Improvement in suicidal ideation after ketamine infusion: relationship to reductions in depression and anxiety. $J$ Psychiatr Res 58:161-166.

Ballard ED, Wills K, Lally N, Richards EM, Luckenbaugh DA, Walls T, Ameli R, Niciu MJ, Brutsche NE, Park L, et al. (2017) Anhedonia as a clinical correlate of suicidal thoughts in clinical ketamine trials. J Affect Disord 218:195-200.

Becker DE and Reed KL (2012) Local anesthetics: review of pharmacological considerations. Anesth Prog 59:90-101, quiz 102-103.

Beilin B, Rusabrov Y, Shapira Y, Roytblat L, Greemberg L, Yardeni IZ, and Bessler H (2007) Low-dose ketamine affects immune responses in humans during the early postoperative period. $\mathrm{Br} J$ Anaesth 99:522-527.

Benoit E (1995) Effects of intravenous anaesthetics on nerve axons. Eur J Anaes thesiol 12:59-70.

Berman RM, Cappiello A, Anand A, Oren DA, Heninger GR, Charney DS, and Krystal JH (2000) Antidepressant effects of ketamine in depressed patients. Biol Psychiatry 47:351-354.

Bhat S, Dao DT, Terrillion CE, Arad M, Smith RJ, Soldatov NM, and Gould TD (2012) CACNA1C (Cav1.2) in the pathophysiology of psychiatric disease. Prog Neurobiol 99:1-14.

Bion JF (1984) Intrathecal ketamine for war surgery: a preliminary study under field conditions. Anaesthesia 39:1023-1028.

Blier P, Zigman D, and Blier J (2012) On the safety and benefits of repeated intravenous injections of ketamine for depression. Biol Psychiatry 72:e11-e12.

Bobo WV and Miller SC (2002) Ketamine as a preferred substance of abuse. Am J Addict 11:332-334.

Bokor G and Anderson PD (2014) Ketamine: an update on its abuse. J Pharm Pract 27:582-586.

Bolze S and Boulieu R (1998) HPLC determination of ketamine, norketamine, and dehydronorketamine in plasma with a high-purity reversed-phase sorbent. Clin Chem 44:560-564.

Bonanno FG (2002) Ketamine in war/tropical surgery (a final tribute to the racemic mixture). Injury 33:323-327.

Bonifazi A, Del Bello F, Mammoli V, Piergentili A, Petrelli R, Cimarelli C, Pellei M, Schepmann D, Wünsch B, Barocelli E, et al. (2015) Novel potent N-methyl-daspartate (NMDA) receptor antagonists or $\sigma 1$ receptor ligands based on properly substituted 1,4-dioxane ring. J Med Chem 58:8601-8615.

Bourke DL, Malit LA, and Smith TC (1987) Respiratory interactions of ketamine and morphine. Anesthesiology 66:153-156.

Bowdle TA, Radant AD, Cowley DS, Kharasch ED, Strassman RJ, and Roy-Byrne PP (1998) Psychedelic effects of ketamine in healthy volunteers: relationship to steady-state plasma concentrations. Anesthesiology 88:82-88.

Bowen WD, Hellewell SB, and McGarry KA (1989) Evidence for a multi-site model of the rat brain sigma receptor. Eur J Pharmacol 163:309-318.

Bree MM, Feller I, and Corssen G (1967) Safety and tolerance of repeated anesthesia with CI 581 (ketamine) in monkeys. Anesth Analg 46:596-600.

Breier A, Adler CM, Weisenfeld N, Su TP, Elman I, Picken L, Malhotra AK, and Pickar D (1998) Effects of NMDA antagonism on striatal dopamine release in healthy subjects: application of a novel PET approach. Synapse 29:142-147.

Bresink I, Danysz W, Parsons CG, and Mutschler E (1995) Different binding affinities of NMDA receptor channel blockers in various brain regions-indication of NMDA receptor heterogeneity. Neuropharmacology 34:533-540.

Can A, Zanos P, Moaddel R, Kang HJ, Dossou KSS, Wainer IW, Cheer JF, Frost DO, Huang X-P, and Gould TD (2016) Effects of ketamine and ketamine metabolites on evoked striatal dopamine release, dopamine receptors, and monoamine transporters. J Pharmacol Exp Ther 359:159-170.

Canuso CM, Singh JB, Fedgchin M, Alphs L, Lane R, Lim P, Pinter C, Hough D, Sanacora G, Manji H, et al. (2018) Efficacy and safety of intranasal esketamine for the rapid reduction of symptoms of depression and suicidality in patients at imminent risk for suicide: results of a double-blind, randomized, placebo-controlled study. Am J Psychiatry DOI: 10.1176/appi.ajp.2018.17060720.

Carliss RD, Radovsky A, Chengelis CP, O'Neill TP, and Shuey DL (2007) Oral administration of dextromethorphan does not produce neuronal vacuolation in the rat brain. Neurotoxicology 28:813-818.

Carr DB, Goudas LC, Denman WT, Brookoff D, Staats PS, Brennen L, Green G, Albin R, Hamilton D, Rogers MC, et al. (2004) Safety and efficacy of intranasal ketamine for the treatment of breakthrough pain in patients with chronic pain: a randomized, double-blind, placebo-controlled, crossover study. Pain 108:17-27.

Catterall WA (2011) Voltage-gated calcium channels. Cold Spring Harb Perspect Biol 3:a003947.

Cavalleri L, Merlo Pich E, Millan MJ, Chiamulera C, Kunath T, Spano PF, and Collo G (2017) Ketamine enhances structural plasticity in mouse mesencephalic and human iPSC-derived dopaminergic neurons via AMPAR-driven BDNF and mTOR signaling. Molecular Psychiatry 23:812.

Chang T and Glazko AJ (1972) A gas chromatographic assay for ketamine in human plasma. Anesthesiology 36:401-404.

Chang T and Glazko AJ (1974) Biotransformation and disposition of ketamine. Int Anesthesiol Clin 12:157-177.

Chen G, Ensor CR, and Bohner B (1966) The neuropharmacology of 2-(omicron-chlorophenyl)2-methylaminocyclohexanoe hydrochloride. J Pharmacol Exp Ther 152:332-339.

Chen X, Shu S, and Bayliss DA (2009) HCN1 channel subunits are a molecular substrate for hypnotic actions of ketamine. J Neurosci 29:600-609.

Cheng PS, Fu CY, Lee CH, Liu C, and Chien CS (2007) GC-MS quantification of ketamine, norketamine, and dehydronorketamine in urine specimens and comparative study using ELISA as the preliminary test methodology. J Chromatogr $B$ Analyt Technol Biomed Life Sci 852:443-449.

Cho JE, Shim JK, Choi YS, Kim DH, Hong SW, and Kwak YL (2009) Effect of lowdose ketamine on inflammatory response in off-pump coronary artery bypass graft surgery. Br J Anaesth 102:23-28

Chong C, Schug SA, Page-Sharp M, Jenkins B, and Ilett KF (2009) Development of a sublingual/oral formulation of ketamine for use in neuropathic pain: preliminary findings from a three-way randomized, crossover study. Clin Drug Investig 29:317-324.

Chu PS, Ma WK, Wong SC, Chu RW, Cheng CH, Wong S, Tse JM, Lau FL, Yiu MK, and Man CW (2008) The destruction of the lower urinary tract by ketamine abuse: a new syndrome? BJU Int 102:1616-1622.

Clements JA and Nimmo WS (1981) Pharmacokinetics and analgesic effect of ketamine in man. Br J Anaesth 53:27-30.

Clements JA, Nimmo WS, and Grant IS (1982) Bioavailability, pharmacokinetics, and analgesic activity of ketamine in humans. J Pharm Sci 71:539-542.

Coates KM and Flood P (2001) Ketamine and its preservative, benzethonium chloride, both inhibit human recombinant $\alpha 7$ and $\alpha 4 \beta 2$ neuronal nicotinic acetylcholine receptors in Xenopus oocytes. Br J Pharmacol 134:871-879.

Cohen ML, Chan SL, Way WL, and Trevor AJ (1973) Distribution in the brain and metabolism of ketamine in the rat after intravenous administration. Anesthesiology 39 : $370-376$

Collier BB (1972) Ketamine and the conscious mind. Anaesthesia 27:120-134

Corazza O, Assi S, and Schifano F (2013) From "Special K" to "Special M": the evolution of the recreational use of ketamine and methoxetamine. CNS Neurosci Ther 19:454-460.

Corssen G and Domino EF (1966) Dissociative anesthesia: further pharmacologic studies and first clinical experience with the phencyclidine derivative CI-581. Anesth Analg 45:29-40.

Craven R (2007) Ketamine. Anaesthesia 62 (Suppl 1):48-53.

Cremer J, Martin M, Redl H, Bahrami S, Abraham C, Graeter T, Haverich A, Schlag G, and Borst HG (1996) Systemic inflammatory response syndrome after cardiac operations. Ann Thorac Surg 61:1714-1720.

Crisp T, Perrotti JM, Smith DL, Stafinsky JL, and Smith DJ (1991) The loca monoaminergic dependency of spinal ketamine. Eur J Pharmacol 194:167-172.

Cusin C, Ionescu DF, Pavone KJ, Akeju O, Cassano P, Taylor N, Eikermann M, Durham K, Swee MB, Chang T, et al. (2017) Ketamine augmentation for outpatients with treatment-resistant depression: preliminary evidence for two-step intravenous dose escalation. Aust N Z J Psychiatry 51:55-64.

Dachs RJ and Innes GM (1997) Intravenous ketamine sedation of pediatric patients in the emergency department. Ann Emerg Med 29:146-150.

Dalgarno PJ and Shewan D (1996) Illicit use of ketamine in Scotland. J Psychoactive Drugs 28:191-199.

Daly EJ, Singh JB, Fedgchin M, Cooper K, Lim P, Shelton RC, Thase ME, Winokur A, Van Nueten L, Manji H, et al. (2018) Efficacy and safety of intranasal esketamine adjunctive to oral antidepressant therapy in treatment-resistant depression: a randomized clinical trial. JAMA Psychiatry 75:139-148.

Dayton PG, Stiller RL, Cook DR, and Perel JM (1983) The binding of ketamine to plasma proteins: emphasis on human plasma. Eur J Clin Pharmacol 24:825-831. De Felice LJ (2017) Monoamine transporters as ionotropic receptors. Trends Neurosci 40:195-196.

De Kock M, Lavand'homme P, and Waterloos H (2001) 'Balanced analgesia' in the perioperative period: is there a place for ketamine? Pain 92:373-380.

De Kock M, Loix S, and Lavand'homme P (2013) Ketamine and peripheral inflammation. CNS Neurosci Ther 19:403-410.

Delini-Stula A (1980) Drug-induced alterations in animal behavior as a tool for the evaluation of antidepressants: correlation with biochemical effects, in Psychotropic Agents: Part I: Antipsychotics and Antidepressants (Hoffmeister F and Stille G eds) pp 505-526, Springer, Berlin.

Desta Z, Moaddel R, Ogburn ET, Xu C, Ramamoorthy A, Venkata SL, Sanghvi M, Goldberg ME, Torjman MC, and Wainer IW (2012) Stereoselective and regiospecific hydroxylation of ketamine and norketamine. Xenobiotica 42:1076-1087.

Diazgranados N, Ibrahim L, Brutsche NE, Newberg A, Kronstein P, Khalife S, Kammerer WA, Quezado Z, Luckenbaugh DA, Salvadore G, et al. (2010a) A randomized add-on trial of an N-methyl-D-aspartate antagonist in treatment-resistant bipolar depression. Arch Gen Psychiatry 67:793-802. 
DiazGranados N, Ibrahim LA, Brutsche NE, Ameli R, Henter ID, Luckenbaugh DA, Machado-Vieira R, and Zarate CA Jr (2010b) Rapid resolution of suicidal ideation after a single infusion of an N-methyl-D-aspartate antagonist in patients with treatment-resistant major depressive disorder. J Clin Psychiatry 71: 1605-1611.

Dinis-Oliveira RJ (2017) Metabolism and metabolomics of ketamine: a toxicological approach. Forensic Sci Res 2:2-10.

Domino EF (2010) Taming the ketamine tiger: 1965. Anesthesiology 113:678-684.

Domino EF, Chodoff P, and Corssen G (1965) Pharmacologic effects of Ci-581, a new dissociative anesthetic, in man. Clin Pharmacol Ther 6:279-291.

Downey D, Dutta A, McKie S, Dawson GR, Dourish CT, Craig K, Smith MA, McCarthy DJ, Harmer CJ, Goodwin GM, et al. (2016) Comparing the actions of lanicemine and ketamine in depression: key role of the anterior cingulate. Eur Neuropsychopharmacol 26:994-1003.

Dravid SM, Erreger K, Yuan H, Nicholson K, Le P, Lyuboslavsky P, Almonte A Murray E, Mosely C, Barber J, et al. (2007) Subunit-specific mechanisms and proton sensitivity of NMDA receptor channel block. J Physiol 581:107-128.

Driesen NR, McCarthy G, Bhagwagar Z, Bloch MH, Calhoun VD, D'Souza DC, Gueorguieva R, He G, Leung HC, Ramani R, et al. (2013) The impact of NMDA receptor blockade on human working memory-related prefrontal function and connectivity. Neuropsychopharmacology 38:2613-2622.

du Jardin KG, Liebenberg N, Müller HK, Elfving B, Sanchez C, and Wegener G (2016) Differential interaction with the serotonin system by S-ketamine, vortioxetine, and fluoxetine in a genetic rat model of depression. Psychopharmacology (Berl) 233:2813-2825.

Dundee JW, Knox JW, Black GW, Moore J, Pandit SK, Bovill J, Clarke RS, Love SH, Elliott J, and Coppel DL (1970) Ketamine as an induction agent in anaesthetics. Lancet 1:1370-1371.

Dundee JW and Lilburn JK (1978) Ketamine-iorazepam: attenuation of psychic sequelae of ketamine by lorazepam. Anaesthesia 33:312-314.

Durieux ME (1995) Inhibition by ketamine of muscarinic acetylcholine receptor function. Anesth Analg 81:57-62.

Ebert B, Mikkelsen S, Thorkildsen C, and Borgbjerg FM (1997) Norketamine, the main metabolite of ketamine, is a non-competitive NMDA receptor antagonist in the rat cortex and spinal cord. Eur J Pharmacol 333:99-104.

Edginton AN, Schmitt W, Voith B, and Willmann S (2006) A mechanistic approach for the scaling of clearance in children. Clin Pharmacokinet 45:683-704.

Eglen RM (2005) Muscarinic receptor subtype pharmacology and physiology. Prog Med Chem 43:105-136.

Eide K, Stubhaug A, Oye I, and Breivik H (1995) Continuous subcutaneous administration of the N-methyl-D-aspartic acid (NMDA) receptor antagonist ketamine in the treatment of post-herpetic neuralgia. Pain 61:221-228.

Eide PK, Jørum E, Stubhaug A, Bremnes J, and Breivik H (1994) Relief of postherpetic neuralgia with the N-methyl-D-aspartic acid receptor antagonist ketamine: a double-blind, cross-over comparison with morphine and placebo. Pain $\mathbf{5 8}$ $347-354$.

Emnett C, Li H, Jiang X, Benz A, Boggiano J, Conyers S, Wozniak DF, Zorumski CF, Reichert DE, and Mennerick S (2016) A clickable analogue of ketamine retains NMDA receptor activity, psychoactivity, and accumulates in neurons. Sci Rep 6 38808

Erdemir H, Huber FC, and Corssen G (1970) Dissociative anesthesia with ketamine: a suitable adjunct to epidural anesthesia. Anesth Analg 49:623-627.

Fanta S, Kinnunen M, Backman JT, and Kalso E (2015) Population pharmacokinetics of S-ketamine and norketamine in healthy volunteers after intravenous and oral dosing. Eur J Clin Pharmacol 71:441-447.

Farber NB, Newcomer JW, and Olney JW (1998) The glutamate synapse in neuropsychiatric disorders: focus on schizophrenia and Alzheimer's disease. Prog Brain Res 116:421-437.

Felser JM and Orban DJ (1982) Dystonic reaction after ketamine abuse. Ann Emerg Med 11:673-675.

Finck AD and Ngai SH (1982) Opiate receptor mediation of ketamine analgesia. Anesthesiology 56:291-297.

Finck AD, Samaniego E, and Ngai SH (1988) Morphine tolerance decreases the analgesic effects of ketamine in mice. Anesthesiology 68:397-400.

Fishback JA, Robson MJ, Xu YT, and Matsumoto RR (2010) Sigma receptors: potential targets for a new class of antidepressant drug. Pharmacol Ther 127: 271-282.

Fix AS, Horn JW, Wightman KA, Johnson CA, Long GG, Storts RW, Farber N, Wozniak DF, and Olney JW (1993) Neuronal vacuolization and necrosis induced by the noncompetitive N-methyl-D-aspartate (NMDA) antagonist MK(+)801 (dizocilpine maleate): a light and electron microscopic evaluation of the rat retrosplenial cortex. Exp Neurol 123:204-215.

Flood P and Krasowski MD (2000) Intravenous anesthetics differentially modulate ligand-gated ion channels. Anesthesiology 92:1418-1425.

Franks NP and Lieb WR (1994) Molecular and cellular mechanisms of general anaesthesia. Nature 367:607-614

Frenkel C and Urban BW (1992) Molecular actions of racemic ketamine on human CNS sodium channels. Br J Anaesth 69:292-297.

Fuchikami M, Thomas A, Liu R, Wohleb ES, Land BB, DiLeone RJ, Aghajanian GK, and Duman RS (2015) Optogenetic stimulation of infralimbic PFC reproduces ketamine's rapid and sustained antidepressant actions. Proc Natl Acad Sci USA 112:8106-8111.

Fukumoto K, Iijima M, and Chaki S (2014) Serotonin-1A receptor stimulation mediates effects of a metabotropic glutamate 2/3 receptor antagonist, 2S-2-amino-2 (1S,2S-2-carboxycycloprop-1-yl)-3-(xanth-9-yl)propanoic acid (LY341495), and an $\mathrm{N}$-methyl-D-aspartate receptor antagonist, ketamine, in the novelty-suppressed feeding test. Psychopharmacology (Berl) 231:2291-2298.

Fukumoto K, Toki H, Iijima M, Hashihayata T, Yamaguchi JI, Hashimoto K, and Chaki S (2017) Antidepressant potential of $(R)$-ketamine in rodent models: comparison with (S)-ketamine. J Pharmacol Exp Ther 361:9-16.
Gage PW and Robertson B (1985) Prolongation of inhibitory postsynaptic currents by pentobarbitone, halothane and ketamine in CA1 pyramidal cells in rat hippocampus. Br J Pharmacol 85:675-681.

Gao M, Rejaei D, and Liu H (2016) Ketamine use in current clinical practice. Acta Pharmacol Sin 37:865-872.

Garfield JM, Garfield FB, Stone JG, Hopkins D, and Johns LA (1972) A comparison of psychologic responses to ketamine and thiopental-nitrous oxide-halothane anesthesia. Anesthesiology 36:329-338.

Geisslinger G, Hering W, Thomann P, Knoll R, Kamp HD, and Brune K (1993) Pharmacokinetics and pharmacodynamics of ketamine enantiomers in surgica patients using a stereoselective analytical method. Br J Anaesth 70:666-671.

Georg A and Friedl A (1991) Identification and characterization of two sigma-like binding sites in the mouse neuroblastoma $\times$ rat glioma hybrid cell line NG108-15. $J$ Pharmacol Exp Ther 259:479-483.

George D, Gálvez V, Martin D, Kumar D, Leyden J, Hadzi-Pavlovic D, Harper S, Brodaty H, Glue P, Taylor R, et al. (2017) Pilot randomized controlled trial of titrated subcutaneous ketamine in older patients with treatment-resistant depression. Am J Geriatr Psychiatry 25:1199-1209.

Gerhard DM, Wohleb ES, and Duman RS (2016) Emerging treatment mechanisms for depression: focus on glutamate and synaptic plasticity. Drug Discov Today 21: $454-464$.

Ghoneim MM, Hinrichs JV, Mewaldt SP, and Petersen RC (1985) Ketamine: behavioral effects of subanesthetic doses. J Clin Psychopharmacol 5:70-77.

Gill JR and Stajíc M (2000) Ketamine in non-hospital and hospital deaths in New York city. J Forensic Sci 45:655-658.

Gilling KE, Jatzke C, Hechenberger M, and Parsons CG (2009) Potency, voltagedependency, agonist concentration-dependency, blocking kinetics and partial untrapping of the uncompetitive N-methyl-D-aspartate (NMDA) channel blocker memantine at human NMDA (GluN1/GluN2A) receptors. Neuropharmacology 56: 866-875.

Goldberg ME, Torjman MC, Schwartzman RJ, Mager DE, and Wainer IW (2010) Pharmacodynamic profiles of ketamine (R)- and (S)- with 5-day inpatient infusion for the treatment of complex regional pain syndrome. Pain Physician 13:379-387.

Gómez de Segura IA, De Rossi R, Santos M, López San-Roman J, Tendillo FJ, and San-Roman F (1998) Epidural injection of ketamine for perineal analgesia in the horse. Vet Surg 27:384-391.

Gonzalez-Burgos G, Cho RY, and Lewis DA (2015) Alterations in cortical network oscillations and parvalbumin neurons in schizophrenia. Biol Psychiatry 77: 1031-1040.

Gorlin AW, Rosenfeld DM, and Ramakrishna H (2016) Intravenous subanesthetic ketamine for perioperative analgesia. J Anaesthesiol Clin Pharmacol 32:160-167.

Gould TD, Georgiou P, Brenner LA, Brundin L, Can A, Courtet P, Donaldson ZR, Dwivedi Y, Guillaume S, Gottesman II, et al. (2017) Animal models to improve our understanding and treatment of suicidal behavior. Transl Psychiatry 7:e1092.

Grant IS, Nimmo WS, and Clements JA (1981) Pharmacokinetics and analgesic effects of i.m. and oral ketamine. Br J Anaesth 53:805-810.

Grant IS, Nimmo WS, McNicol LR, and Clements JA (1983) Ketamine disposition in children and adults. $\mathrm{Br}$ J Anaesth 55:1107-1111.

Green CJ, Knight J, Precious S, and Simpkin S (1981) Ketamine alone and combined with diazepam or xylazine in laboratory animals: a 10 year experience. Lab Anim 15:163-170.

Green SM, Roback MG, Kennedy RM, and Krauss B (2011) Clinical practice guideline for emergency department ketamine dissociative sedation: 2011 update. Ann Emerg Med 57:449-461.

Grott Zanicotti C, Perez D, and Glue P (2013) Case report: long-term mood response to repeat dose intramuscular ketamine in a depressed patient with advanced cancer. J Palliat Med 16:719-720.

Gupta A, Devi LA, and Gomes I (2011) Potentiation of $\mu$-opioid receptor-mediated signaling by ketamine. $J$ Neurochem 119:294-302.

Haas DA and Harper DG (1992) Ketamine: a review of its pharmacologic properties and use in ambulatory anesthesia. Anesth Prog 39:61-68.

Haeseler G, Tetzlaff D, Bufler J, Dengler R, Münte S, Hecker H, and Leuwer M (2003) Blockade of voltage-operated neuronal and skeletal muscle sodium channels by S(+)- and R(-)-ketamine. Anesth Analg 96:1019-1026.

Hagelberg NM, Peltoniemi MA, Saari TI, Kurkinen KJ, Laine K, Neuvonen PJ, and Olkkola KT (2010) Clarithromycin, a potent inhibitor of CYP3A, greatly increases exposure to oral S-ketamine. Eur J Pain 14:625-629.

Han Y, Heuermann RJ, Lyman KA, Fisher D, Ismail QA, and Chetkovich DM (2017) HCN-channel dendritic targeting requires bipartite interaction with TRIP8b and regulates antidepressant-like behavioral effects. Mol Psychiatry 22:458-465.

Hance AJ, Winters WD, Quam DD, Benthuysen JL, and Cadd GG (1989) Catalepsy induced by combinations of ketamine and morphine: potentiation, antagonism, tolerance and cross-tolerance in the rat. Neuropharmacology 28:109-116.

Hansen G, Jensen SB, Chandresh L, and Hilden T (1988) The psychotropic effect of ketamine. J Psychoactive Drugs 20:419-425.

Hara K, Yanagihara N, Minami K, Ueno S, Toyohira Y, Sata T, Kawamura M, Brüss M, Bönisch H, Shigematsu A, et al. (1998a) Ketamine interacts with the noradrenaline transporter at a site partly overlapping the desipramine binding site. Naunyn Schmiedebergs Arch Pharmacol 358:328-333.

Hara Y, Chugun A, Nakaya H, and Kondo H (1998b) Tonic block of the sodium and calcium currents by ketamine in isolated guinea pig ventricular myocytes. $J$ Vet Med Sci 60:479-483.

Hare BD, Ghosal S, and Duman RS (2017) Rapid acting antidepressants in chronic stress models: molecular and cellular mechanisms. Chronic Stress (Thousand Oaks) 1: DOI: $10.1177 / 2470547017697317$.

Hargreaves RJ, Hill RG, and Iversen LL (1994) Neuroprotective NMDA antagonists: the controversy over their potential for adverse effects on cortical neuronal morphology. Acta Neurochir Suppl (Wien) 60:15-19. 
Harris JA, Biersner RJ, Edwards D, and Bailey LW (1975) Attention, learning, and personality during ketamine emergence: a pilot study. Anesth Analg 54:169-172. Harrison NL and Simmonds MA (1985) Quantitative studies on some antagonists of $\mathrm{N}$-methyl D-aspartate in slices of rat cerebral cortex. Br J Pharmacol 84:381-391. Hashimoto K (2014) Blood D-serine levels as a predictive biomarker for the rapid antidepressant effects of the NMDA receptor antagonist ketamine. Psychopharmacology (Berl) 231:4081-4082.

Hatakeyama N, Yamazaki M, Shibuya N, Yamamura S, and Momose Y (2001) Effects of ketamine on voltage-dependent calcium currents and membrane potentials in single bullfrog atrial cells. J Anesth 15:149-153.

Hawksworth C and Serpell M (1998) Intrathecal anesthesia with ketamine. Reg Anesth Pain Med 23:283-288.

Henneberger C, Papouin T, Oliet SHR, and Rusakov DA (2010) Long-term potentiation depends on release of D-serine from astrocytes. Nature 463:232-236.

Hennein HA, Ebba H, Rodriguez JL, Merrick SH, Keith FM, Bronstein MH, Leung JM, Mangano DT, Greenfield LJ, and Rankin JS (1994) Relationship of the proinflammatory cytokines to myocardial ischemia and dysfunction after uncomplicated coronary revascularization. J Thorac Cardiovasc Surg 108:626-635.

Hetem LA, Danion JM, Diemunsch P, and Brandt C (2000) Effect of a subanesthetic dose of ketamine on memory and conscious awareness in healthy volunteers. Psychopharmacology (Berl) 152:283-288.

Hijazi Y and Boulieu R (2002) Contribution of CYP3A4, CYP2B6, and CYP2C9 isoforms to N-demethylation of ketamine in human liver microsomes. Drug Metab Dispos 30:853-858.

Himmelseher S and Pfenninger E (1998) The clinical use of S-(+)-ketamine-a determination of its place. Anasthesiol Intensivmed Notfallmed Schmerzther 33:764-770.

Hirlinger WK and Dick W (1984) Intramuscular ketamine analgesia in emergency patients. II. Clinical study of traumatized patients. Anaesthesist 33:272-275.

Hirota K, Hashimoto Y, and Lambert DG (2002) Interaction of intravenous anesthetics with recombinant human M1-M3 muscarinic receptors expressed in Chinese hamster ovary cells. Anesth Analg 95:1607-1610.

Hirota K and Lambert DG (2011) Ketamine: new uses for an old drug? Br J Anaesth 107:123-126.

Hirota K, Okawa H, Appadu BL, Grandy DK, Devi LA, and Lambert DG (1999) Stereoselective interaction of ketamine with recombinant mu, kappa, and delta opioid receptors expressed in Chinese hamster ovary cells. Anesthesiology 90:174-182.

Hirsiger S, Simmen HP, Werner CM, Wanner GA, and Rittirsch D (2012) Danger signals activating the immune response after trauma. Mediators Inflamm 2012 315941.

Ho KK and Flood P (2004) Single amino acid residue in the extracellular portion of transmembrane segment 2 in the nicotinic alpha7 acetylcholine receptor modulates sensitivity to ketamine. Anesthesiology 100:657-662.

Hodgkin AL and Huxley AF (1952) Currents carried by sodium and potassium ions through the membrane of the giant axon of Loligo. $J$ Physiol 116:449-472.

Homayoun H and Moghaddam B (2007) NMDA receptor hypofunction produces opposite effects on prefrontal cortex interneurons and pyramidal neurons. J Neurosci 27:11496-11500.

Honey GD, Honey RA, Sharar SR, Turner DC, Pomarol-Clotet E, Kumaran D, Simons JS, Hu X, Rugg MD, Bullmore ET, et al. (2005) Impairment of specific episodic memory processes by sub-psychotic doses of ketamine: the effects of levels of processing at encoding and of the subsequent retrieval task Psychopharmacology (Berl) 181:445-457.

Hornik CP, Gonzalez D, van den Anker J, Atz AM, Yogev R, Poindexter BB, Ng KC, Delmore P, Harper BL, Melloni C, et al. (2018) Population pharmacokinetics of intramuscular and intravenous ketamine in children. J Clin Pharmacol 54: DOI 10.1002/jcph.1116.

Hu YD, Xiang YT, Fang JX, Zu S, Sha S, Shi H, Ungvari GS, Correll CU, Chiu HF, Xue Y, et al. (2016) Single i.v. ketamine augmentation of newly initiated escitalopram for major depression: results from a randomized, placebo-controlled 4-week study. Psychol Med 46:623-635.

Huang HC and Jiang ZF (2009) Accumulated amyloid-beta peptide and hyperphosphorylated tau protein: relationship and links in Alzheimer's disease. $J \mathrm{Alz}$ heimers Dis 16:15-27.

Huettner JE and Bean BP (1988) Block of N-methyl-D-aspartate-activated current by the anticonvulsant MK-801: selective binding to open channels. Proc Natl Acad Sci USA 85:1307-1311.

Huge V, Lauchart M, Magerl W, Schelling G, Beyer A, Thieme D, and Azad SC (2010) Effects of low-dose intranasal (S)-ketamine in patients with neuropathic pain. Eur $J$ Pain 14:387-394.

Hustveit O, Maurset A, and Oye I (1995) Interaction of the chiral forms of ketamine with opioid, phencyclidine, sigma and muscarinic receptors. Pharmacol Toxicol 77: 355-359

Ibrahim L, Diazgranados N, Franco-Chaves J, Brutsche N, Henter ID, Kronstein P, Moaddel R, Wainer I, Luckenbaugh DA, Manji HK, et al. (2012) Course of improvement in depressive symptoms to a single intravenous infusion of ketamine vs add-on riluzole: results from a 4-week, double-blind, placebo-controlled study. Neuropsychopharmacology 37:1526-1533.

Idvall J, Ahlgren I, Aronsen KR, and Stenberg P (1979) Ketamine infusions: pharmacokinetics and clinical effects. Br J Anaesth 51:1167-1173.

Idvall J, Holasek J, and Stenberg P (1983) Rectal ketamine for induction of anaesthesia in children. Anaesthesia 38:60-64.

Ihmsen H, Geisslinger G, and Schüttler J (2001) Stereoselective pharmacokinetics of ketamine: R(-)-ketamine inhibits the elimination of $\mathrm{S}(+)$-ketamine. Clin Pharmacol Ther 70:431-438.

Ionescu DF, Luckenbaugh DA, Niciu MJ, Richards EM, and Zarate CA Jr (2015) A single infusion of ketamine improves depression scores in patients with anxious bipolar depression. Bipolar Disord 17:438-443.

Irifune M, Sato T, Kamata Y, Nishikawa T, Dohi T, and Kawahara M (2000) Evidence for GABA(A) receptor agonistic properties of ketamine: convulsive and anesthetic behavioral models in mice. Anesth Analg 91:230-236.
Izumi Y and Zorumski CF (2014) Metaplastic effects of subanesthetic ketamine on CA1 hippocampal function. Neuropharmacology 86:273-281.

Jacob TC, Moss SJ, and Jurd R (2008) GABA(A) receptor trafficking and its role in the dynamic modulation of neuronal inhibition. Nat Rev Neurosci 9:331-343.

Jahr CE (1992) High probability opening of NMDA receptor channels by L-glutamate. Science 255:470-472.

Jansen K (1989) Near death experience and the NMDA receptor. BMJ 298:1708.

Jansen KL (2000) A review of the nonmedical use of ketamine: use, users and consequences. J Psychoactive Drugs 32:419-433.

Jansen KL and Darracot-Cankovic R (2001) The nonmedical use of ketamine, part two: a review of problem use and dependence. J Psychoactive Drugs 33:151-158.

Jevtovic-Todorovic V, Wozniak DF, Benshoff ND, and Olney JW (2001) A comparative evaluation of the neurotoxic properties of ketamine and nitrous oxide. Brain Res 895:264-267.

Johansson J, Sjöberg J, Nordgren M, Sandström E, Sjöberg F, and Zetterström H (2013) Prehospital analgesia using nasal administration of S-ketamine-a case series. Scand J Trauma Resusc Emerg Med 21:38.

Jourdi H, Hsu YT, Zhou M, Qin Q, Bi X, and Baudry M (2009) Positive AMPA receptor modulation rapidly stimulates $\mathrm{BDNF}$ release and increases dendritic mRNA translation. $J$ Neurosci 29:8688-8697.

Jozwiak K, Haginaka J, Moaddel R, and Wainer IW (2002) Displacement and nonlinear chromatographic techniques in the investigation of interaction of noncompetitive inhibitors with an immobilized alpha3beta4 nicotinic acetylcholine receptor liquid chromatographic stationary phase. Anal Chem 74:4618-4624.

Kadriu B, Gold PW, Luckenbaugh DA, Lener MS, Ballard ED, Niciu MJ, Henter ID, Park LT, De Sousa RT, Yuan P, et al. (2017) Acute ketamine administration corrects abnormal inflammatory bone markers in major depressive disorder. Mol Psychiatry [published ahead of print].

Kang H, Park P, Bortolotto ZA, Brandt SD, Colestock T, Wallach J, Collingridge GL, and Lodge D (2017) Ephenidine: a new psychoactive agent with ketamine-like NMDA receptor antagonist properties. Neuropharmacology 112:144-149.

Kapur S and Seeman P (2001) Ketamine has equal affinity for NMDA receptors and the high-affinity state of the dopamine D2 receptor. Biol Psychiatry 49:954-957.

Kapur S and Seeman P (2002) NMDA receptor antagonists ketamine and PCP have direct effects on the dopamine $\mathrm{D}(2)$ and serotonin 5-HT(2)receptors-implications for models of schizophrenia. Mol Psychiatry 7:837-844.

Karch SB and Drummer OH (2015) Dissociative anesthetics, in Karch's Pathology of Drug Abuse, 5th ed, pp 697-754, CRS Press, Boca Raton, FL.

Kathirvel S, Sadhasivam S, Saxena A, Kannan TR, and Ganjoo P (2000) Effects of intrathecal ketamine added to bupivacaine for spinal anaesthesia. Anaesthesia $\mathbf{5 5}$ 899-904

Kavalali ET and Monteggia LM (2012) Synaptic mechanisms underlying rapid antidepressant action of ketamine. Am J Psychiatry 169:1150-1156.

Kawasaki C, Kawasaki T, Ogata M, Nandate K, and Shigematsu A (2001) Ketamine isomers suppress superantigen-induced proinflammatory cytokine production in human whole blood. Can J Anaesth 48:819-823.

Kawasaki T, Ogata M, Kawasaki C, Ogata J, Inoue Y, and Shigematsu A (1999) Ketamine suppresses proinflammatory cytokine production in human whole blood in vitro. Anesth Analg 89:665-669.

Ke X, Ding Y, Xu K, He H, Wang D, Deng X, Zhang X, Zhou Y, Zhou C, Liu Y, et al. (2018) The profile of cognitive impairments in chronic ketamine users. Psychiatry Res 266:124-131.

Kegeles LS, Martinez D, Kochan LD, Hwang DR, Huang Y, Mawlawi O, Suckow RF, Van Heertum RL, and Laruelle M (2002) NMDA antagonist effects on striatal dopamine release: positron emission tomography studies in humans. Synapse 43: 19-29.

Keita H, Lecharny JB, Henzel D, Desmonts JM, and Mantz J (1996) Is inhibition of dopamine uptake relevant to the hypnotic action of i.v. anaesthetics? Br J Anaesth 77:254-256.

Kennedy RM, Porter FL, Miller JP, and Jaffe DM (1998) Comparison of fentanyl/midazolam with ketamine/midazolam for pediatric orthopedic emergencies. Pediatrics 102:956-963.

Kharasch ED and Labroo R (1992) Metabolism of ketamine stereoisomers by human liver microsomes. Anesthesiology 77:1201-1207.

Khorramzadeh E and Lotfy AO (1973) The use of ketamine in psychiatry. Psychosomatics 14:344-346.

Kieffer BL and Gavériaux-Ruff C (2002) Exploring the opioid system by gene knockout. Prog Neurobiol 66:285-306.

Kim CS, Chang PY, and Johnston D (2012) Enhancement of dorsal hippocampal activity by knockdown of HCN1 channels leads to anxiolytic- and antidepressantlike behaviors. Neuron 75:503-516.

Kishimoto T, Chawla JM, Hagi K, Zarate CA, Kane JM, Bauer M, and Correll CU (2016) Single-dose infusion ketamine and non-ketamine N-methyl-d-aspartate receptor antagonists for unipolar and bipolar depression: a meta-analysis of efficacy, safety and time trajectories. Psychol Med 46:1459-1472.

Klepstad P, Maurset A, Moberg ER, and Oye I (1990) Evidence of a role for NMDA receptors in pain perception. Eur J Pharmacol 187:513-518.

Kohrs R and Durieux ME (1998) Ketamine: teaching an old drug new tricks. Anesth Analg 87:1186-1193.

Koike H and Chaki S (2014) Requirement of AMPA receptor stimulation for the sustained antidepressant activity of ketamine and LY341495 during the forced swim test in rats. Behav Brain Res 271:111-115.

Koike H, Iijima M, and Chaki S (2011) Involvement of AMPA receptor in both the rapid and sustained antidepressant-like effects of ketamine in animal models of depression. Behav Brain Res 224:107-111.

Kokkinou M, Ashok AH, and Howes OD (2018) The effects of ketamine on dopaminergic function: meta-analysis and review of the implications for neuropsychiatric disorders. Mol Psychiatry 23:59-69.

Kornhuber J, Mack-Burkhardt F, Kornhuber ME, and Riederer P (1989) [3H]MK-801 binding sites in post-mortem human frontal cortex. Eur J Pharmacol 162:483-490. 
Kortekaas R, Maguire RP, van Waarde A, Leenders KL, and Elsinga PH (2008) Despite irreversible binding, PET tracer [11C]-SA5845 is suitable for imaging of drug competition at sigma receptors: the cases of ketamine and haloperidol. Neurochem Int 53:45-50.

Kotermanski SE and Johnson JW (2009) Mg2+ imparts NMDA receptor subtype selectivity to the Alzheimer's drug memantine. J Neurosci 29:2774-2779.

Kotermanski SE, Wood JT, and Johnson JW (2009) Memantine binding to a superficial site on NMDA receptors contributes to partial trapping. $J$ Physiol 587: $4589-4604$

Krystal JH and D'Souza DC (2001) Comment on "ketamine has equal affinity for NMDA receptors and the high-affinity state of the dopamine $\mathrm{D}(2)$ receptor." Biol Psychiatry 50:555-556.

Krystal JH, Karper LP, Seibyl JP, Freeman GK, Delaney R, Bremner JD, Heninger GR, Bowers MB Jr, and Charney DS (1994) Subanesthetic effects of the noncompetitive NMDA antagonist, ketamine, in humans: psychotomimetic, perceptual, cognitive, and neuroendocrine responses. Arch Gen Psychiatry 51:199-214.

Krystal JH, Madonick S, Perry E, Gueorguieva R, Brush L, Wray Y, Belger A, and D'Souza DC (2006) Potentiation of low dose ketamine effects by naltrexone: potential implications for the pharmacotherapy of alcoholism. Neuropsychopharmacology 31:1793-1800.

Kuroda K, Suzumura K, Shirakawa T, Hiraishi T, Nakahara Y, Fushiki H, Honda S, Naraoka H, Miyoshi S, and Aoki Y (2015) Investigation of mechanisms for MK-801induced neurotoxicity utilizing metabolomic approach. Toxicol Sci 146:344-353.

Lahti AC, Weiler MA, Tamara Michaelidis BA, Parwani A, and Tamminga CA (2001) Effects of ketamine in normal and schizophrenic volunteers. Neuropsychopharmacology 25:455-467.

Lai R, Katalinic N, Glue P, Somogyi AA, Mitchell PB, Leyden J, Harper S, and Loo CK (2014) Pilot dose-response trial of i.v. ketamine in treatment-resistant depression. World J Biol Psychiatry 15:579-584.

Lally N, Nugent AC, Luckenbaugh DA, Ameli R, Roiser JP, and Zarate CA (2014) Anti-anhedonic effect of ketamine and its neural correlates in treatment-resistant bipolar depression. Transl Psychiatry 4:e469.

Lally N, Nugent AC, Luckenbaugh DA, Niciu MJ, Roiser JP, and Zarate CA Jr (2015) Neural correlates of change in major depressive disorder anhedonia following openlabel ketamine. J Psychopharmacol 29:596-607.

Lankveld DP, Bull S, Van Dijk P, Fink-Gremmels J, and Hellebrekers LJ (2005) Ketamine inhibits LPS-induced tumour necrosis factor-alpha and interleukin-6 in an equine macrophage cell line. Vet Res 36:257-262.

Lapidus KA, Levitch CF, Perez AM, Brallier JW, Parides MK, Soleimani L, Feder A, Iosifescu DV, Charney DS, and Murrough JW (2014) A randomized controlled trial of intranasal ketamine in major depressive disorder. Biol Psychiatry $\mathbf{7 6}$ 970-976

Larsen B, Hoff G, Wilhelm W, Buchinger H, Wanner GA, and Bauer M (1998) Effect of intravenous anesthetics on spontaneous and endotoxin-stimulated cytokine response in cultured human whole blood. Anesthesiology 89:1218-1227.

Laskowski K, Stirling A, McKay WP, and Lim HJ (2011) A systematic review of intravenous ketamine for postoperative analgesia. Can J Anaesth 58:911-923.

Lauretti GR, Lima IC, Reis MP, Prado WA, and Pereira NL (1999) Oral ketamine and transdermal nitroglycerin as analgesic adjuvants to oral morphine therapy for cancer pain management. Anesthesiology 90:1528-1533.

Lepack AE, Fuchikami M, Dwyer JM, Banasr M, and Duman RS (2014) BDNF release is required for the behavioral actions of ketamine. Int $J$ Neuropsychopharmacol 18: DOI: 10.1093/ijnp/pyu033.

Lerma J, Zukin RS, and Bennett MV (1991) Interaction of Mg2+ and phencyclidine in use-dependent block of NMDA channels. Neurosci Lett 123:187-191.

Leung LY and Baillie TA (1986) Comparative pharmacology in the rat of ketamine and its two principal metabolites, norketamine and (Z)-6-hydroxynorketamine. J Med Chem 29:2396-2399.

Lewis AS, Vaidya SP, Blaiss CA, Liu Z, Stoub TR, Brager DH, Chen X, Bender RA Estep CM, Popov AB, et al. (2011) Deletion of the hyperpolarization-activated cyclic nucleotide-gated channel auxiliary subunit TRIP8b impairs hippocampal Ih localization and function and promotes antidepressant behavior in mice. $J \mathrm{Neu}$ rosci 31:7424-7440.

Li CT, Chen MH, Lin WC, Hong CJ, Yang BH, Liu RS, Tu PC, and Su TP (2016) The effects of low-dose ketamine on the prefrontal cortex and amygdala in treatmentresistant depression: a randomized controlled study. Hum Brain Mapp 37: 1080-1090.

Li CY, Chou TC, Wong CS, Ho ST, Wu CC, Yen MH, and Ding YA (1997) Ketamine inhibits nitric oxide synthase in lipopolysaccharide-treated rat alveolar macrophages. Can J Anaesth 44:989-995.

Li J, Chen FF, Chen XD, and Zhou C (2014) Inhibition of HCN1 channels by ketamine accounts for its antidepressant actions. Sichuan Da Xue Xue Bao Yi Xue Ban 45:888-892, 932

Li N, Lee B, Liu RJ, Banasr M, Dwyer JM, Iwata M, Li XY, Aghajanian G, and Duman RS (2010) mTOR-dependent synapse formation underlies the rapid antidepressant effects of NMDA antagonists. Science 329:959-964.

Li Q, Shi L, Lu G, Yu HL, Yeung FK, Wong NK, Sun L, Liu K, Yew D, Pan F, et al (2017) Chronic ketamine exposure causes white matter microstructural abnormalities in adolescent cynomolgus monkeys. Front Neurosci 11:285.

Liao Y, Tang J, Ma M, Wu Z, Yang M, Wang X, Liu T, Chen X, Fletcher PC, and Hao W (2010) Frontal white matter abnormalities following chronic ketamine use: a diffusion tensor imaging study. Brain 133:2115-2122.

Lilius T, Kangas E, Niemi M, Rauhala P, and Kalso E (2018a) Ketamine and norketamine attenuate oxycodone tolerance markedly less than that of morphine: from behaviour to drug availability. $B r$ J Anaesth 120:818-826.

Lilius TO, Viisanen H, Jokinen V, Niemi M, Kalso EA, and Rauhala PV (2018b) Interactions of ( $2 \mathrm{~S}, 6 \mathrm{~S} ; 2 \mathrm{R}, 6 \mathrm{R})$-Hydroxynorketamine, a Secondary Metabolite of (R,S)-Ketamine, with Morphine. Basic Clin Pharmacol Toxicol 122:481-488.

Lim DK (2003) Ketamine associated psychedelic effects and dependence. Singapore Med J 44:31-34.
Lin HR and Lua AC (2004) Detection of acid-labile conjugates of ketamine and its metabolites in urine samples collected from pub participants. J Anal Toxicol 28: $181-186$

Lin LH, Chen LL, Zirrolli JA, and Harris RA (1992) General anesthetics potentiate gamma-aminobutyric acid actions on gamma-aminobutyric acidA receptors expressed by Xenopus oocytes: lack of involvement of intracellular calcium. $J$ Pharmacol Exp Ther 263:569-578.

Lisek M, Boczek T, Ferenc B, and Zylinska L (2016) Regional brain dysregulation of $\mathrm{Ca}(2+)$-handling systems in ketamine-induced rat model of experimental psychosis. Cell Tissue Res 363:609-620.

Little B, Chang T, Chucot L, Dill WA, Enrile LL, Glazko AJ, Jassani M, Kretchmer $\mathrm{H}$, and Sweet AY (1972) Study of ketamine as an obstetric anesthetic agent. Am J Obstet Gynecol 113:247-260.

Littlewood CL, Cash D, Dixon AL, Dix SL, White CT, O’Neill MJ, Tricklebank M, and Williams SCR (2006) Using the BOLD MR signal to differentiate the stereoisomers of ketamine in the rat. NeuroImage 32:1733-1746.

Lockhart CH and Nelson WL (1974) The relationship of ketamine requirement to age in pediatric patients. Anesthesiology 40:507-508.

Lodge D, Anis NA, and Burton NR (1982) Effects of optical isomers of ketamine on excitation of cat and rat spinal neurones by amino acids and acetylcholine. Neurosci Lett 29:281-286.

Lodge DJ, Behrens MM, and Grace AA (2009) A loss of parvalbumin-containing interneurons is associated with diminished oscillatory activity in an animal model of schizophrenia. J Neurosci 29:2344-2354.

Loix S, De Kock M, and Henin P (2011) The anti-inflammatory effects of ketamine: state of the art. Acta Anaesthesiol Belg 62:47-58

Loo CK, Gálvez V, O’Keefe E, Mitchell PB, Hadzi-Pavlovic D, Leyden J, Harper S, Somogyi AA, Lai R, Weickert CS, et al. (2016) Placebo-controlled pilot trial testing dose titration and intravenous, intramuscular and subcutaneous routes for ketamine in depression. Acta Psychiatr Scand 134:48-56.

Lucas G, Rymar VV, Sadikot AF, and Debonnel G (2008) Further evidence for an antidepressant potential of the selective sigma1 agonist SA 4503: electrophysiological, morphological and behavioural studies. Int $J$ Neuropsychopharmacol 11: $485-495$.

Lüthi A and McCormick DA (1998) H-current: properties of a neuronal and network pacemaker. Neuron 21:9-12.

Lynch DR, Lawrence JJ, Lenz S, Anegawa NJ, Dichter M, and Pritchett DB (1995) Pharmacological characterization of heterodimeric NMDA receptors composed of NR 1a and 2B subunits: differences with receptors formed from NR 1a and $2 \mathrm{~A}$. J Neurochem 64:1462-1468.

Ma M, Ren Q, Fujita Y, Yang C, Dong C, Ohgi Y, Futamura T, and Hashimoto K (2017) Alterations in amino acid levels in mouse brain regions after adjunctive treatment of brexpiprazole with fluoxetine: comparison with (R)-ketamine. Psychopharmacology (Berl) 234:3165-3173.

MacDonald JF, Bartlett MC, Mody I, Pahapill P, Reynolds JN, Salter MW, Schneiderman JH, and Pennefather PS (1991) Actions of ketamine, phencyclidine and MK-801 on NMDA receptor currents in cultured mouse hippocampal neurones. J Physiol 432:483-508.

MacDonald JF, Miljkovic Z, and Pennefather P (1987) Use-dependent block of excitatory amino acid currents in cultured neurons by ketamine. $J$ Neurophysiol 58: 251-266.

Maeng S, Zarate CA Jr, Du J, Schloesser RJ, McCammon J, Chen G, and Manji HK (2008) Cellular mechanisms underlying the antidepressant effects of ketamine: role of alpha-amino-3-hydroxy-5-methylisoxazole-4-propionic acid receptors. Biol Psychiatry 63:349-352

Malaquin JM (1984) Ketamine via rectal route for the induction of pediatric anesthesia. Cah Anesthesiol 32:373-374.

Malhotra AK, Pinals DA, Adler CM, Elman I, Clifton A, Pickar D, and Breier A (1997) Ketamine-induced exacerbation of psychotic symptoms and cognitive impairment in neuroleptic-free schizophrenics. Neuropsychopharmacology 17: $141-150$

Malhotra AK, Pinals DA, Weingartner H, Sirocco K, Missar CD, Pickar D, and Breier A (1996) NMDA receptor function and human cognition: the effects of ketamine in healthy volunteers. Neuropsychopharmacology 14:301-307.

Malinovsky JM, Servin F, Cozian A, Lepage JY, and Pinaud M (1996) Ketamine and norketamine plasma concentrations after i.v., nasal and rectal administration in children. Br J Anaesth 77:203-207.

Mantz J, Lecharny JB, Laudenbach V, Henzel D, Peytavin G, and Desmonts JM (1995) Anesthetics affect the uptake but not the depolarization-evoked release of GABA in rat striatal synaptosomes. Anesthesiology 82:502-511.

Marchetti F, Coutaux A, Bellanger A, Magneux C, Bourgeois P, and Mion G (2015) Efficacy and safety of oral ketamine for the relief of intractable chronic pain: a retrospective 5-year study of 51 patients. Eur J Pain 19:984-993.

Marietta MP, Way WL, Castagnoli N Jr, and Trevor AJ (1977) On the pharmacology of the ketamine enantiomorphs in the rat. J Pharmacol Exp Ther 202: $157-165$

Martin DC, Adams RJ, and Watkins CA (1988) Inhibition of synaptosomal serotonin uptake by Ketalar. Res Commun Chem Pathol Pharmacol 62:129-132.

Martin DC, Introna RP, and Aronstam RS (1990) Inhibition of neuronal 5-HT uptake by ketamine, but not halothane, involves disruption of substrate recognition by the transporter. Neurosci Lett 112:99-103.

Martin LL, Bouchal RL, and Smith DJ (1982) Ketamine inhibits serotonin uptake in vivo. Neuropharmacology 21:113-118.

Mason K, Cottrell AM, Corrigan AG, Gillatt DA, and Mitchelmore AE (2010) Ketamine-associated lower urinary tract destruction: a new radiological challenge. Clin Radiol 65:795-800.

Mathew SJ, Murrough JW, aan het Rot M, Collins KA, Reich DL, and Charney DS (2010) Riluzole for relapse prevention following intravenous ketamine in treatment-resistant depression: a pilot randomized, placebo-controlled continuation trial. Int J Neuropsychopharmacol 13:71-82. 
Mathisen LC, Skjelbred P, Skoglund LA, and Oye I (1995) Effect of ketamine, an NMDA receptor inhibitor, in acute and chronic orofacial pain. Pain 61:215-220.

Matsuno K, Kobayashi T, Tanaka MK, and Mita S (1996) Sigma 1 receptor subtype is involved in the relief of behavioral despair in the mouse forced swimming test. Eur J Pharmacol 312:267-271.

McCarthy DA, Chen G, Kaump DH, and Ensor C (1965) General anesthetic and other pharmacological properties of 2-(O-chlorophenyl)-2-methylamino cyclohexanone Hcl (Ci-581). J New Drugs 5:21-33.

McGuinness SK, Wasiak J, Cleland H, Symons J, Hogan L, Hucker T, and Mahar PD (2011) A systematic review of ketamine as an analgesic agent in adult burn injuries. Pain Med 12:1551-1558.

McIntyre P, McLatchie LM, Chambers A, Phillips E, Clarke M, Savidge J, Toms C, Peacock M, Shah K, Winter J, et al. (2001) Pharmacological differences between the human and rat vanilloid receptor 1 (VR1). Br J Pharmacol 132:1084-1094.

Meng E, Wu S-T, Cha T-L, Sun G-H, Yu D-S, and Chang S-Y (2013) A murderer of young bladders: ketamine-associated cystitis. Urol Sci 24:113-116.

Mikkelsen S, Ilkjaer S, Brennum J, Borgbjerg FM, and Dahl JB (1999) The effect of naloxone on ketamine-induced effects on hyperalgesia and ketamine-induced side effects in humans. Anesthesiology 90:1539-1545.

Miller OH, Yang L, Wang CC, Hargroder EA, Zhang Y, Delpire E, and Hall BJ (2014) GluN2B-containing NMDA receptors regulate depression-like behavior and are critical for the rapid antidepressant actions of ketamine. eLife 3:e03581.

Mineur YS and Picciotto MR (2010) Nicotine receptors and depression: revisiting and revising the cholinergic hypothesis. Trends Pharmacol Sci 31:580-586.

Mion G and Villevieille T (2013) Ketamine pharmacology: an update (pharmacodynamics and molecular aspects, recent findings). CNS Neurosci Ther 19:370-380.

Miyasaka M and Domino EF (1968) Neural mechanisms of ketamine-induced anesthesia. Int $J$ Neuropharmacol 7:557-573.

Moaddel R, Abdrakhmanova G, Kozak J, Jozwiak K, Toll L, Jimenez L, Rosenberg A Tran T, Xiao Y, Zarate CA, et al. (2013) Sub-anesthetic concentrations of (R,S) ketamine metabolites inhibit acetylcholine-evoked currents in $\alpha 7$ nicotinic acetylcholine receptors. Eur J Pharmacol 698:228-234.

Moaddel R, Luckenbaugh DA, Xie Y, Villaseñor A, Brutsche NE, Machado-Vieira R, Ramamoorthy A, Lorenzo MP, Garcia A, Bernier M, et al. (2015a) D-serine plasma concentration is a potential biomarker of (R,S)-ketamine antidepressant response in subjects with treatment-resistant depression. Psychopharmacology (Berl) 232:399-409.

Moaddel R, Sanghvi M, Dossou KS, Ramamoorthy A, Green C, Bupp J, Swezey R, O'Loughlin K, and Wainer IW (2015b) The distribution and clearance of (2S,6S)hydroxynorketamine, an active ketamine metabolite, in Wistar rats. Pharmacol Res Perspect 3:e00157.

Moaddel R, Sanghvi M, Ramamoorthy A, Jozwiak K, Singh N, Green C, O’Loughlin K, Torjman M, and Wainer IW (2016) Subchronic administration of (R,S)-ketamine induces ketamine ring hydroxylation in Wistar rats. J Pharm Biomed Anal 127: $3-8$

Moaddel R, Venkata SL, Tanga MJ, Bupp JE, Green CE, Iyer L, Furimsky A, Goldberg ME, Torjman MC, and Wainer IW (2010) A parallel chiral-achiral liquid chromatographic method for the determination of the stereoisomers of ketamine and ketamine metabolites in the plasma and urine of patients with complex regional pain syndrome. Talanta 82:1892-1904.

Moghaddam B, Adams B, Verma A, and Daly D (1997) Activation of glutamatergic neurotransmission by ketamine: a novel step in the pathway from NMDA receptor blockade to dopaminergic and cognitive disruptions associated with the prefrontal cortex. J Neurosci 17:2921-2927.

Morgan CJ and Curran HV; Independent Scientific Committee on Drugs (2012) Ketamine use: a review. Addiction 107:27-38.

Morgan CJ, Mofeez A, Brandner B, Bromley L, and Curran HV (2004) Acute effects of ketamine on memory systems and psychotic symptoms in healthy volunteers. Neuropsychopharmacology 29:208-218.

Morgan CJ, Rossell SL, Pepper F, Smart J, Blackburn J, Brandner B, and Curran HV (2006) Semantic priming after ketamine acutely in healthy volunteers and following chronic self-administration in substance users. Biol Psychiatry 59:265-272.

Morris PJ, Moaddel R, Zanos P, Moore CE, Gould T, Zarate CA Jr, and Thomas CJ (2017) Synthesis and N-methyl-d-aspartate (NMDA) receptor activity of ketamine metabolites. Org Lett 19:4572-4575.

Mössner LD, Schmitz A, Theurillat R, Thormann W, and Mevissen M (2011) Inhibition of cytochrome P450 enzymes involved in ketamine metabolism by use of liver microsomes and specific cytochrome P450 enzymes from horses, dogs, and humans. Am J Vet Res 72:1505-1513.

Muetzelfeldt L, Kamboj SK, Rees H, Taylor J, Morgan CJ, and Curran HV (2008) Journey through the K-hole: phenomenological aspects of ketamine use. Drug Alcohol Depend 95:219-229.

Murrough JW, Iosifescu DV, Chang LC, Al Jurdi RK, Green CE, Perez AM, Iqbal S, Pillemer S, Foulkes A, Shah A, et al. (2013a) Antidepressant efficacy of ketamine in treatment-resistant major depression: a two-site randomized controlled trial. Am J Psychiatry 170:1134-1142.

Murrough JW, Perez AM, Pillemer S, Stern J, Parides MK, aan het Rot M, Collins KA, Mathew SJ, Charney DS, and Iosifescu DV (2013b) Rapid and longer-term antidepressant effects of repeated ketamine infusions in treatment-resistant major depression. Biol Psychiatry 74:250-256.

Murrough JW, Soleimani L, DeWilde KE, Collins KA, Lapidus KA, Iacoviello BM, Lener M, Kautz M, Kim J, Stern JB, et al. (2015) Ketamine for rapid reduction of suicidal ideation: a randomized controlled trial. Psychol Med 45:3571-3580.

Myers AM, Charifson PS, Owens CE, Kula NS, McPhail AT, Baldessarini RJ, Booth RG, and Wyrick SD (1994) Conformational analysis, pharmacophore identification, and comparative molecular field analysis of ligands for the neuromodulatory sigma 3 receptor. J Med Chem 37:4109-4117.

Nemeth CL, Paine TA, Rittiner JE, Béguin C, Carroll FI, Roth BL, Cohen BM, and Carlezon WA Jr (2010) Role of kappa-opioid receptors in the effects of salvinorin $\mathrm{A}$ and ketamine on attention in rats. Psychopharmacology (Berl) 210: $263-274$.
Newcomer JW, Farber NB, Jevtovic-Todorovic V, Selke G, Melson AK, Hershey T, Craft S, and Olney JW (1999) Ketamine-induced NMDA receptor hypofunction as a model of memory impairment and psychosis. Neuropsychopharmacology 20: 106-118

Newport DJ, Carpenter LL, McDonald WM, Potash JB, Tohen M, and Nemeroff CB; APA Council of Research Task Force on Novel Biomarkers and Treatments (2015) Ketamine and other NMDA antagonists: early clinical trials and possible mechanisms in depression. Am J Psychiatry 172:950-966.

Newton K and Dixit VM (2012) Signaling in innate immunity and inflammation. Cold Spring Harb Perspect Biol 4: DOI: 10.1101/cshperspect.a006049.

Nishimura M, Sato K, Okada T, Yoshiya I, Schloss P, Shimada S, and Tohyama M (1998) Ketamine inhibits monoamine transporters expressed in human embryonic kidney 293 cells. Anesthesiology 88:768-774.

Oka Y, Murata A, Nishijima J, Yasuda T, Hiraoka N, Ohmachi Y, Kitagawa K, Yasuda T, Toda H, Tanaka N, et al. (1992) Circulating interleukin 6 as a useful marker for predicting postoperative complications. Cytokine 4:298-304.

Olney JW, Labruyere J, and Price MT (1989) Pathological changes induced in cerebrocortical neurons by phencyclidine and related drugs. Science 244:1360-1362. Olney JW, Labruyere J, Wang G, Wozniak DF, Price MT, and Sesma MA (1991) NMDA antagonist neurotoxicity: mechanism and prevention. Science 254:1515-1518. Orser BA, Pennefather PS, and MacDonald JF (1997) Multiple mechanisms of ketamine blockade of N-methyl-D-aspartate receptors. Anesthesiology 86:903-917.

Oye I, Paulsen O, and Maurset A (1992) Effects of ketamine on sensory perception evidence for a role of N-methyl-D-aspartate receptors. J Pharmacol Exp Ther 260: 1209-1213.

Pacheco Dda F, Romero TR, and Duarte ID (2014) Central antinociception induced by ketamine is mediated by endogenous opioids and $\mu$ - and $\delta$-opioid receptors. Brain Res 1562:69-75.

Pal HR, Berry N, Kumar R, and Ray R (2002) Ketamine dependence. Anaesth Intensive Care 30:382-384.

Pande AC, Genève J, Scherrer B, Smith F, Leadbetter RA, and de Meynard C (1999) A placebo-controlled trial of igmesine in the treatment of major depression. Eur Neuropsychopharmacol $\mathbf{9}: 138$.

Paoletti P, Bellone C, and Zhou Q (2013) NMDA receptor subunit diversity: impact on receptor properties, synaptic plasticity and disease. Nat Rev Neurosci 14:383-400 Park M, Newman LE, Gold PW, Luckenbaugh DA, Yuan P, Machado-Vieira R, and Zarate CA Jr (2017) Change in cytokine levels is not associated with rapid antidepressant response to ketamine in treatment-resistant depression. J Psychiatr Res 84:113-118.

Parsons CG, Panchenko VA, Pinchenko VO, Tsyndrenko AY, and Krishtal OA (1996) Comparative patch-clamp studies with freshly dissociated rat hippocampal and striatal neurons on the NMDA receptor antagonistic effects of amantadine and memantine. Eur $J$ Neurosci 8:446-454.

Parsons CG, Quack G, Bresink I, Baran L, Przegalinski E, Kostowski W, Krzascik P Hartmann S, and Danysz W (1995) Comparison of the potency, kinetics and voltage-dependency of a series of uncompetitive NMDA receptor antagonists in vitro with anticonvulsive and motor impairment activity in vivo. Neuropharmacology 34:1239-1258.

Paul RK, Singh NS, Khadeer M, Moaddel R, Sanghvi M, Green CE, O'Loughlin K, Torjman MC, Bernier M, and Wainer IW (2014) (R,S)-Ketamine metabolites (R,S)norketamine and (2S,6S)-hydroxynorketamine increase the mammalian target of rapamycin function. Anesthesiology 121:149-159.

Peltoniemi MA, Hagelberg NM, Olkkola KT, and Saari TI (2016) Ketamine: a review of clinical pharmacokinetics and pharmacodynamics in anesthesia and pain therapy. Clin Pharmacokinet 55:1059-1077.

Peltoniemi MA, Saari TI, Hagelberg NM, Laine K, Kurkinen KJ, Neuvonen PJ, and Olkkola KT (2012) Rifampicin has a profound effect on the pharmacokinetics of oral S-ketamine and less on intravenous S-ketamine. Basic Clin Pharmacol Toxicol 111:325-332.

Pereira EF, Hilmas C, Santos MD, Alkondon M, Maelicke A, and Albuquerque EX (2002) Unconventional ligands and modulators of nicotinic receptors. J Neurobiol 53:479-500.

Perumal DK, Adhimoolam M, Selvaraj N, Lazarus SP, and Mohammed MA (2015) Midazolam premedication for ketamine-induced emergence phenomenon: a prospective observational study. J Res Pharm Pract 4:89-93.

Petrenko AB, Yamakura T, Sakimura K, and Baba H (2014) Defining the role of NMDA receptors in anesthesia: are we there yet? Eur J Pharmacol 723:29-37.

Pfenninger EG, Durieux ME, and Himmelseher S (2002) Cognitive impairment after small-dose ketamine isomers in comparison to equianalgesic racemic ketamine in human volunteers. Anesthesiology 96:357-366.

Pham TH, Defaix C, Xu X, Deng SX, Fabresse N, Alvarez JC, Landry DW, Brachman RA, Denny CA, and Gardier AM (2017a) Common neurotransmission recruited in (R,S)-ketamine and (2R,6R)-hydroxynorketamine-induced sustained antidepressantlike effects. Biol Psychiatry [published ahead of print].

Pham TH, Mendez-David I, Defaix C, Guiard BP, Tritschler L, David DJ, and Gardier AM (2017b) Ketamine treatment involves medial prefrontal cortex serotonin to induce a rapid antidepressant-like activity in BALB/cJ mice. Neuropharmacology 112:198-209.

Phelps LE, Brutsche N, Moral JR, Luckenbaugh DA, Manji HK, and Zarate CA Jr (2009) Family history of alcohol dependence and initial antidepressant response to an N-methyl-D-aspartate antagonist. Biol Psychiatry 65:181-184.

Philip NS, Carpenter LL, Tyrka AR, and Price LH (2010) Nicotinic acetylcholine receptors and depression: a review of the preclinical and clinical literature. Psychopharmacology (Berl) 212:1-12.

Pomarol-Clotet E, Honey GD, Murray GK, Corlett PR, Absalom AR, Lee M, McKenna PJ, Bullmore ET, and Fletcher PC (2006) Psychological effects of ketamine in healthy volunteers: phenomenological study. Br J Psychiatry 189:173-179.

Porter RH and Greenamyre JT (1995) Regional variations in the pharmacology of NMDA receptor channel blockers: implications for therapeutic potential. J Neurochem 64:614-623. 
Portmann S, Kwan HY, Theurillat R, Schmitz A, Mevissen M, and Thormann W (2010) Enantioselective capillary electrophoresis for identification and characterization of human cytochrome P450 enzymes which metabolize ketamine and norketamine in vitro. J Chromatogr A 1217:7942-7948.

Price RB, Nock MK, Charney DS, and Mathew SJ (2009) Effects of intravenous ketamine on explicit and implicit measures of suicidality in treatment-resistant depression. Biol Psychiatry 66:522-526.

Rao LK, Flaker AM, Friedel CC, and Kharasch ED (2016) Role of cytochrome P4502B6 polymorphisms in ketamine metabolism and clearance. Anesthesiology 125:1103-1112.

Rasmussen KG, Lineberry TW, Galardy CW, Kung S, Lapid MI, Palmer BA, Ritter MJ, Schak KM, Sola CL, Hanson AJ, et al. (2013) Serial infusions of low-dose ketamine for major depression. J Psychopharmacol 27:444-450.

Reich DL and Silvay G (1989) Ketamine: an update on the first twenty-five years of clinical experience. Can J Anaesth 36:186-197.

Reid C, Hatton R, and Middleton P (2011) Case report: prehospital use of intranasal ketamine for paediatric burn injury. Emerg Med $J$ 28:328-329.

Remérand F, Le Tendre C, Baud A, Couvret C, Pourrat X, Favard L, Laffon M, and Fusciardi J (2009) The early and delayed analgesic effects of ketamine after total hip arthroplasty: a prospective, randomized, controlled, double-blind study. Anesth Analg 109:1963-1971.

Reynolds IJ and Miller RJ (1989) Ifenprodil is a novel type of N-methyl-D-aspartate receptor antagonist: interaction with polyamines. Mol Pharmacol 36:758-765.

Riva-Posse P, Reiff CM, Edwards JA, Job GP, Galendez GC, Garlow SJ, Saah TC, Dunlop BW, and McDonald WM (2018) Blood pressure safety of subanesthetic ketamine for depression: a report on 684 infusions. J Affect Disord DOI: 10.1016/j. jad.2018.02.025 [published ahead of print].

Robson MJ, Elliott M, Seminerio MJ, and Matsumoto RR (2012) Evaluation of sigma $(\sigma)$ receptors in the antidepressant-like effects of ketamine in vitro and in vivo. Eur Neuropsychopharmacol 22:308-317.

Rolan P, Lim S, Sunderland V, Liu Y, and Molnar V (2014) The absolute bioavailability of racemic ketamine from a novel sublingual formulation. $\mathrm{Br} \mathrm{J}$ Clin Pharmacol 77:1011-1016.

Rosa PB, Neis VB, Ribeiro CM, Moretti M, and Rodrigues AL (2016) Antidepressantlike effects of ascorbic acid and ketamine involve modulation of GABAA and GABAB receptors. Pharmacol Rep 68:996-1001.

Roytblat L, Korotkoruchko A, Katz J, Glazer M, Greemberg L, and Fisher A (1993) Postoperative pain: the effect of low-dose ketamine in addition to general anesthesia. Anesth Analg 77:1161-1165.

Roytblat L, Talmor D, Rachinsky M, Greemberg L, Pekar A, Appelbaum A, Gurman GM, Shapira Y, and Duvdenani A (1998) Ketamine attenuates the interleukin-6 response after cardiopulmonary bypass. Anesth Analg 87:266-271.

Rush AJ, Trivedi MH, Wisniewski SR, Nierenberg AA, Stewart JW, Warden D, Niederehe G, Thase ME, Lavori PW, Lebowitz BD, et al. (2006) Acute and longerterm outcomes in depressed outpatients requiring one or several treatment steps: a STAR*D report. Am J Psychiatry 163:1905-1917.

Russabrov E, Davies JM, Bessler H, Greemberg L, Roytblat L, Yardeni I-Z, Artru AA, and Shapira Y (2008) Effect of ketamine on inflammatory and immune responses after short- duration surgery in obese patients. Open Anesthesiol J 2:40-45.

Ryder S, Way WL, and Trevor AJ (1978) Comparative pharmacology of the optical isomers of ketamine in mice. Eur J Pharmacol 49:15-23.

Sage M and Laird SM (1972) Ketamine anaesthesia for burns surgery. Postgrad Med $J$ 48:156-161.

Sałat K, Siwek A, Starowicz G, Librowski T, Nowak G, Drabik U, Gajdosz R, and Popik P (2015) Antidepressant-like effects of ketamine, norketamine and dehydronorketamine in forced swim test: role of activity at NMDA receptor. $\mathrm{Neu}$ ropharmacology 99:301-307.

Salmi E, Långsjö JW, Aalto S, Någren K, Metsähonkala L, Kaisti KK, Korpi ER, Hietala J, and Scheinin H (2005) Subanesthetic ketamine does not affect $11 \mathrm{C}$ flumazenil binding in humans. Anesth Analg 101:722-725.

Schnoebel R, Wolff M, Peters SC, Bräu ME, Scholz A, Hempelmann G, Olschewski H, and Olschewski A (2005) Ketamine impairs excitability in superficial dorsal horn neurones by blocking sodium and voltage-gated potassium currents. $\mathrm{Br} J$ Pharmacol 146:826-833.

Scholfield CN (1980) Potentiation of inhibition by general anaesthetics in neurones of the olfactory cortex in vitro. Pflugers Arch 383:249-255.

Schüttler J, Stanski DR, White PF, Trevor AJ, Horai Y, Verotta D, and Sheiner LB (1987) Pharmacodynamic modeling of the EEG effects of ketamine and its enantiomers in man. J Pharmacokinet Biopharm 15:241-253.

Seeman P and Kapur S (2003) Anesthetics inhibit high-affinity states of dopamine D2 and other G-linked receptors. Synapse 50:35-40.

Seeman P, Ko F, and Tallerico T (2005) Dopamine receptor contribution to the action of PCP, LSD and ketamine psychotomimetics. Mol Psychiatry 10:877-883.

Segmiller F, Rüther T, Linhardt A, Padberg F, Berger M, Pogarell O, Möller HJ, Kohler C, and Schüle C (2013) Repeated S-ketamine infusions in therapy resistant depression: a case series. J Clin Pharmacol 53:996-998.

Sekerci C, Dönmez A, Ateş Y, and Okten F (1996) Oral ketamine premedication in children (placebo controlled double-blind study). Eur J Anaesthesiol 13:606-611.

Selye H (1976) Forty years of stress research: principal remaining problems and misconceptions. Can Med Assoc J 115:53-56.

Shaffer CL, Osgood SM, Smith DL, Liu J, and Trapa PE (2014) Enhancing ketamine translational pharmacology via receptor occupancy normalization. Neuropharmacology 86:174-180.

Shah MM (2014) Cortical HCN channels: function, trafficking and plasticity. $J$ Physiol 592:2711-2719.

Shahani R, Streutker C, Dickson B, and Stewart RJ (2007) Ketamine-associated ulcerative cystitis: a new clinical entity. Urology 69:810-812.

Sharif NA, Nunes JL, and Whiting RL (1991) Pharmacological characterization of the $\mathrm{N}$-methyl-D-aspartate (NMDA) receptor-channel in rodent and dog brain and rat spinal cord using [3H]MK-801 binding. Neurochem Res 16:563-569.
Shimada T, Yamazaki H, Mimura M, Inui Y, and Guengerich FP (1994) Interindividual variations in human liver cytochrome P-450 enzymes involved in the oxidation of drugs, carcinogens and toxic chemicals: studies with liver microsomes of 30 Japanese and 30 Caucasians. J Pharmacol Exp Ther 270:414-423.

Shimaoka M, Iida T, Ohara A, Taenaka N, Mashimo T, Honda T, and Yoshiya I (1996) Ketamine inhibits nitric oxide production in mouse-activated macrophagelike cells. $\mathrm{Br}$ J Anaesth 77:238-242.

Shirayama Y and Hashimoto K (2018) Lack of antidepressant effects of (2R,6R)hydroxynorketamine in a rat learned helplessness model: comparison with (R)ketamine. Int $J$ Neuropsychopharmacol 21:84-88.

Short B, Fong J, Galvez V, Shelker W, and Loo CK (2018) Side-effects associated with ketamine use in depression: a systematic review. Lancet Psychiatry 5:65-78.

Siegel RK (1978) Phencyclidine and ketamine intoxication: a study of four populations of recreational users. NIDA Res Monogr 21:119-147.

Singh JB, Fedgchin M, Daly E, Xi L, Melman C, De Bruecker G, Tadic A, Sienaert P, Wiegand F, Manji $\mathrm{H}$, et al. (2016a) Intravenous esketamine in adult treatmentresistant depression: a double-blind, double-randomization, placebo-controlled study. Biol Psychiatry 80:424-431.

Singh JB, Fedgchin M, Daly EJ, De Boer P, Cooper K, Lim P, Pinter C, Murrough JW, Sanacora G, Shelton RC, et al. (2016b) A double-blind, randomized, placebocontrolled, dose-frequency study of intravenous ketamine in patients with treatment-resistant depression. Am J Psychiatry 173:816-826.

Singh NS, Bernier M, Camandola S, Khadeer MA, Moaddel R, Mattson MP, and Wainer IW (2015) Enantioselective inhibition of d-serine transport by (S)ketamine. $\mathrm{Br} J$ Pharmacol DOI: 10.1111/bph.13239 [published ahead of print].

Singh NS, Paul RK, Ramamoorthy A, Torjman MC, Moaddel R, Bernier M, and Wainer IW (2013) Nicotinic acetylcholine receptor antagonists alter the function and expression of serine racemase in PC-12 and 1321N1 cells. Cell Signal 25:2634-2645.

Singh NS, Rutkowska E, Plazinska A, Khadeer M, Moaddel R, Jozwiak K, Bernier M, and Wainer IW (2016c) Ketamine metabolites enantioselectively decrease intracellular D-serine concentrations in PC-12 cells. PLoS One 11:e0149499.

Singh NS, Zarate CA Jr, Moaddel R, Bernier M, and Wainer IW (2014) What is hydroxynorketamine and what can it bring to neurotherapeutics? Expert Rev Neurother 14:1239-1242.

Sinner B and Graf BM (2008) Ketamine. Handb Exp Pharmacol 14:313-333.

Skeldon SC and Goldenberg SL (2014) Urological complications of illicit drug use. Nat Rev Urol 11:169-177.

Skuza G and Rogóz Z (2002) A potential antidepressant activity of SA4503, a selective sigma 1 receptor agonist. Behav Pharmacol 13:537-543.

Smith DJ, Bouchal RL, deSanctis CA, Monroe PJ, Amedro JB, Perrotti JM, and Crisp $\mathrm{T}$ (1987) Properties of the interaction between ketamine and opiate binding sites in vivo and in vitro. Neuropharmacology 26:1253-1260.

Smith DJ, Perrotti JM, Mansell AL, and Monroe PJ (1985) Ketamine analgesia is not related to an opiate action in the periaqueductal gray region of the rat brain. Pain 21:253-265.

Smith GS, Schloesser R, Brodie JD, Dewey SL, Logan J, Vitkun SA, Simkowitz P, Hurley A, Cooper T, Volkow ND, et al. (1998) Glutamate modulation of dopamine measured in vivo with positron emission tomography (PET) and 11C-raclopride in normal human subjects. Neuropsychopharmacology 18:18-25.

Sofia RD and Harakal JJ (1975) Evaluation of ketamine $\mathrm{HCl}$ for anti-depressant activity. Arch Int Pharmacodyn Ther 214:68-74.

Stein C (2016) Opioid receptors. Annu Rev Med 67:433-451.

Stewart CE (2001) Ketamine as a street drug. Emerg Med Serv 30:30, 32, 34 passim. Strayer RJ and Nelson LS (2008) Adverse events associated with ketamine for procedural sedation in adults. Am J Emerg Med 26:985-1028.

Stubhaug A, Breivik H, Eide PK, Kreunen M, and Foss A (1997) Mapping of punctuate hyperalgesia around a surgical incision demonstrates that ketamine is a powerful suppressor of central sensitization to pain following surgery. Acta Anaesthesiol Scand 41:1124-1132.

Sun L, Li Q, Li Q, Zhang Y, Liu D, Jiang H, Pan F, and Yew DT (2014) Chronic ketamine exposure induces permanent impairment of brain functions in adolescent cynomolgus monkeys. Addict Biol 19:185-194.

Sun W and Wessinger WD (2004) Characterization of the non-competitive antagonist binding site of the NMDA receptor in dark Agouti rats. Life Sci 75:1405-1415.

Sussman DR (1974) A comparative evaluation of ketamine anesthesia in children and adults. Anesthesiology 40:459-464.

Suzuki K, Nosyreva E, Hunt KW, Kavalali ET, and Monteggia LM (2017) Effects of a ketamine metabolite on synaptic NMDAR function. Nature 546:E1-E3.

Suzuki M, Haraguti S, Sugimoto K, Kikutani T, Shimada Y, and Sakamoto A (2006) Low-dose intravenous ketamine potentiates epidural analgesia after thoracotomy. Anesthesiology 105:111-119.

Szymkowicz SM, Finnegan N, and Dale RM (2013) A 12-month naturalistic observation of three patients receiving repeat intravenous ketamine infusions for their treatment-resistant depression. J Affect Disord 147:416-420.

Takeyama K, Yoshikawa M, Oka T, Kawaguchi M, Suzuki T, and Hashimoto A (2006) Ketamine enhances the expression of serine racemase and D-amino acid oxidase mRNAs in rat brain. Eur J Pharmacol 540:82-86.

Tanaka M, Sato M, Saito A, and Nishikawa T (2000) Reevaluation of rectal ketamine premedication in children: comparison with rectal midazolam. Anesthesiology 93 $1217-1224$

Temme L, Schepmann D, Schreiber JA, Frehland B, and Wünsch B (2018) Comparative pharmacological study of common NMDA receptor open channel blockers regarding their affinity and functional activity toward GluN2A and GluN2B NMDA receptors. ChemMedChem 13:446-452.

Thomson AM, West DC, and Lodge D (1985) An N-methylaspartate receptormediated synapse in rat cerebral cortex: a site of action of ketamine? Nature 313: 479-481.

Traber DL and Wilson RD (1969) Involvement of the sympathetic nervous system in the pressor response to ketamine. Anesth Analg 48:248-252. 
Traber DL, Wilson RD, and Priano LL (1970) The effect of beta-adrenergic blockade on the cardiopulmonary response to ketamine. Anesth Analg 49:604-613.

Trescot AM, Datta S, Lee M, and Hansen H (2008) Opioid pharmacology. Pain Physician 11:S133-S153.

Tsai TH, Cha TL, Lin CM, Tsao CW, Tang SH, Chuang FP, Wu ST, Sun GH, Yu DS, and Chang SY (2009) Ketamine-associated bladder dysfunction. Int J Urol 16: 826-829.

Tsze DS, Steele DW, Machan JT, Akhlaghi F, and Linakis JG (2012) Intranasal ketamine for procedural sedation in pediatric laceration repair: a preliminary report. Pediatr Emerg Care 28:767-770.

Turfus SC, Parkin MC, Cowan DA, Halket JM, Smith NW, Braithwaite RA Elliot SP, Steventon GB, and Kicman AT (2009) Use of human microsomes and deuterated substrates: an alternative approach for the identification of novel metabolites of ketamine by mass spectrometry. Drug Metab Dispos 37: 1769-1778.

Valentine GW, Mason GF, Gomez R, Fasula M, Watzl J, Pittman B, Krystal JH, and Sanacora G (2011) The antidepressant effect of ketamine is not associated with changes in occipital amino acid neurotransmitter content as measured by $[(1) \mathrm{H}]$ MRS. Psychiatry Res 191:122-127.

Vickers BA, Lee W, and Hunsberger J (2017) A case report: subanesthetic ketamine infusion for treatment of cancer-related pain produces urinary urge incontinence. A A Case Rep 8:219-221.

Virtue RW, Alanis JM, Mori M, Lafargue RT, Vogel JH, and Metcalf DR (1967) An anesthetic agent: 2-orthochlorophenyl, 2-methylamino cyclohexanone $\mathrm{HCl}$ (CI-581). Anesthesiology 28:823-833.

Vollenweider FX, Leenders KL, Oye I, Hell D, and Angst J (1997) Differential psychopathology and patterns of cerebral glucose utilisation produced by (S)- and (R)-ketamine in healthy volunteers using positron emission tomography (PET). Eur Neuropsychopharmacol 7:25-38.

Vollenweider FX, Vontobel P, Øye I, Hell D, and Leenders KL (2000) Effects of (S)-ketamine on striatal dopamine: a [11C]raclopride PET study of a model psychosis in humans. J Psychiatr Res 34:35-43.

Vyklicky V, Korinek M, Smejkalova T, Balik A, Krausova B, Kaniakova M, Lichnerova K, Cerny J, Krusek J, Dittert I, et al. (2014) Structure, function, and pharmacology of NMDA receptor channels. Physiol Res 63 (Suppl 1): S191-S203.

Wagner LE II, Gingrich KJ, Kulli JC, and Yang J (2001) Ketamine blockade of voltage-gated sodium channels: evidence for a shared receptor site with local anesthetics. Anesthesiology 95:1406-1413.

Wahl-Schott C and Biel M (2009) HCN channels: structure, cellular regulation and physiological function. Cell Mol Life Sci 66:470-494.

Walker AK, Budac DP, Bisulco S, Lee AW, Smith RA, Beenders B, Kelley KW, and Dantzer R (2013) NMDA receptor blockade by ketamine abrogates lipopolysaccharide-induced depressive-like behavior in C57BL/6J mice. Neuropsychopharmacology 38:1609-1616.

Wallach J, Kang H, Colestock T, Morris H, Bortolotto ZA, Collingridge GL, Lodge D, Halberstadt AL, Brandt SD, and Adejare A (2016) Pharmacological investigations of the dissociative 'legal highs' diphenidine, methoxphenidine and analogues. PLoS One 11:e0157021.

Wan LB, Levitch CF, Perez AM, Brallier JW, Iosifescu DV, Chang LC, Foulkes A Mathew SJ, Charney DS, and Murrough JW (2015) Ketamine safety and tolerability in clinical trials for treatment-resistant depression. J Clin Psychiatry $\mathbf{7 6}$ 247-252.

Wang C, Zheng D, Xu J, Lam W, and Yew DT (2013) Brain damages in ketamine addicts as revealed by magnetic resonance imaging. Front Neuroanat 7:23.

Wang J, Mack AL, Coop A, and Matsumoto RR (2007) Novel sigma (sigma) receptor agonists produce antidepressant-like effects in mice. Eur Neuropsychopharmacol 17:708-716.

Watanabe M, Yoshikawa M, Takeyama K, Hashimoto A, Kobayashi H, and Suzuki T (2010) Subchronic administration of ketamine decreases the mRNA expression of serine racemase in rat brain. Tokai J Exp Clin Med 35:137-143.

Weber F, Wulf H, Gruber M, and Biallas R (2004) S-ketamine and s-norketamine plasma concentrations after nasal and i.v. administration in anesthetized children. Paediatr Anaesth 14:983-988.

Wei IH, Chen KT, Tsai MH, Wu CH, Lane HY, and Huang CC (2017) Acute amino acid d-serine administration, similar to ketamine, produces antidepressant-like effects through identical mechanisms. J Agric Food Chem 65:10792-10803.

Weiner AL, Vieira L, McKay CA, and Bayer MJ (2000) Ketamine abusers presenting to the emergency department: a case series. J Emerg Med 18:447-451.

Weisman H (1971) Anesthesia for pediatric ophthalmology. Ann Ophthalmol 3:229-232.

Weksler N, Ovadia L, Muati G, and Stav A (1993) Nasal ketamine for paediatric premedication. Can $J$ Anaesth 40:119-121.

White PF, Ham J, Way WL, and Trevor AJ (1980) Pharmacology of ketamine isomers in surgical patients. Anesthesiology 52:231-239.

White PF, Schüttler J, Shafer A, Stanski DR, Horai Y, and Trevor AJ (1985) Comparative pharmacology of the ketamine isomers: studies in volunteers. $\mathrm{Br} J$ Anaesth 57:197-203.

White PF, Way WL, and Trevor AJ (1982) Ketamine-its pharmacology and therapeutic uses. Anesthesiology 56:119-136.

Wieber J, Gugler R, Hengstmann JH, and Dengler HJ (1975) Pharmacokinetics of ketamine in man. Anaesthesist 24:260-263.

Wilkins LK, Girard TA, and Cheyne JA (2012) Anomalous bodily-self experiences among recreational ketamine users. Cogn Neuropsychiatry 17:415-430.

Wohleb ES, Gerhard D, Thomas A, and Duman RS (2017) Molecular and cellular mechanisms of rapid-acting antidepressants ketamine and scopolamine. Curr Neuropharmacol 15:11-20.

Wolff $\mathrm{K}$ and Winstock AR (2006) Ketamine: from medicine to misuse. CNS Drugs 20: 199-218.

Wolosker H, Dumin E, Balan L, and Foltyn VN (2008) D-amino acids in the brain: D-serine in neurotransmission and neurodegeneration. FEBS J 275:3514-3526.
Wong EH, Kemp JA, Priestley T, Knight AR, Woodruff GN, and Iversen LL (1986) The anticonvulsant MK- 801 is a potent N-methyl-D-aspartate antagonist. Proc Natl Acad Sci USA 83:7104-7108.

Wong EH, Knight AR, and Woodruff GN (1988) [3H]MK-801 labels a site on the $\mathrm{N}$-methyl-D-aspartate receptor channel complex in rat brain membranes. $J \mathrm{Neu}$ rochem 50:274-281.

Wood JD and Hertz L (1980) Ketamine-induced changes in the GABA system of mouse brain. Neuropharmacology 19:805-808.

Woolf TF and Adams JD (1987) Biotransformation of ketamine, (Z)-6-hydroxyketamine, and (E)-6-hydroxyketamine by rat, rabbit, and human liver microsomal preparations. Xenobiotica 17:839-847.

Wray NH, Schappi JM, Singh H, Senese NB, and Rasenick MM (2018) NMDARindependent, cAMP-dependent antidepressant actions of ketamine. Mol Psychiatry DOI: $10.1038 / \mathrm{s} 41380-018-0083-8$ [published ahead of print].

Wu YN and Johnson SW (1996) Pharmacological characterization of inward current evoked by N-methyl-D-aspartate in dopamine neurons in the rat brain slice. $J$ Pharmacol Exp Ther 279:457-463.

Yamakage M, Hirshman CA, and Croxton TL (1995) Inhibitory effects of thiopental, ketamine, and propofol on voltage-dependent $\mathrm{Ca} 2+$ channels in porcine tracheal smooth muscle cells. Anesthesiology 83:1274-1282.

Yamakura T, Chavez-Noriega LE, and Harris RA (2000) Subunit-dependent inhibition of human neuronal nicotinic acetylcholine receptors and other ligandgated ion channels by dissociative anesthetics ketamine and dizocilpine. Anesthesiology 92:1144-1153.

Yamakura T, Mori H, Masaki H, Shimoji K, and Mishina M (1993) Different sensitivities of NMDA receptor channel subtypes to non-competitive antagonists. $\mathrm{Neu}$ roreport 4:687-690.

Yamakura T and Shimoji K (1999) Subunit- and site-specific pharmacology of the NMDA receptor channel. Prog Neurobiol 59:279-298.

Yamamoto S, Ohba H, Nishiyama S, Harada N, Kakiuchi T, Tsukada H, and Domino EF (2013) Subanesthetic doses of ketamine transiently decrease serotonin transporter activity: a PET study in conscious monkeys. Neuropsychopharmacology 38 2666-2674

Yamanaka H, Yokoyama C, Mizuma H, Kurai S, Finnema SJ, Halldin C, Doi H, and Onoe $\mathrm{H}$ (2014) A possible mechanism of the nucleus accumbens and ventral pallidum 5-HT1B receptors underlying the antidepressant action of ketamine: a PET study with macaques. Transl Psychiatry 4:e342.

Yamazaki M, Ito Y, Kuze S, Shibuya N, and Momose Y (1992) Effects of ketamine on voltage-dependent $\mathrm{Ca} 2+$ currents in single smooth muscle cells from rabbit portal vein. Pharmacology 45:162-169.

Yanagihara Y, Kariya S, Ohtani M, Uchino K, Aoyama T, Yamamura Y, and Iga T (2001) Involvement of CYP2B6 in n-demethylation of ketamine in human liver microsomes. Drug Metab Dispos 29:887-890.

Yanagihara Y, Ohtani M, Kariya S, Uchino K, Hiraishi T, Ashizawa N, Aoyama T, Yamamura Y, Yamada Y, and Iga T (2003) Plasma concentration profiles of ketamine and norketamine after administration of various ketamine preparations to healthy Japanese volunteers. Biopharm Drug Dispos 24:37-43.

Yang C, Han M, Zhang JC, Ren Q, and Hashimoto K (2016) Loss of parvalbuminimmunoreactivity in mouse brain regions after repeated intermittent administration of esketamine, but not R-ketamine. Psychiatry Res 239:281-283.

Yang C, Qu Y, Abe M, Nozawa D, Chaki S, and Hashimoto K (2017) (R)-Ketamine shows greater potency and longer lasting antidepressant effects than its metabolite (2R,6R)-hydroxynorketamine. Biol Psychiatry 82:e43-e44.

Yang C, Shirayama Y, Zhang JC, Ren Q, Yao W, Ma M, Dong C, and Hashimoto K (2015) R-ketamine: a rapid-onset and sustained antidepressant without psychotomimetic side effects. Transl Psychiatry 5:e632.

Yang J, Li W, Duan M, Zhou Z, Lin N, Wang Z, Sun J, and Xu J (2005) Large dose ketamine inhibits lipopolysaccharide-induced acute lung injury in rats. Inflamm Res 54:133-137.

Yao N, Skiteva O, Zhang X, Svenningsson P, and Chergui K (2017) Ketamine and its metabolite (2R,6R)-hydroxynorketamine induce lasting alterations in glutamatergic synaptic plasticity in the mesolimbic circuit. Mol Psychiatry DOI 10.1038/mp.2017.239 [published ahead of print]

Yeung LY, Wai MS, Fan M, Mak YT, Lam WP, Li Z, Lu G, and Yew DT (2010) Hyperphosphorylated tau in the brains of mice and monkeys with long-term administration of ketamine. Toxicol Lett 193:189-193.

Zanos P and Gould TD (2018a) Intracellular signaling pathways involved in (S)- and (R)-ketamine antidepressant actions. Biol Psychiatry 83:2-4.

Zanos P, Thompson SM, Duman RS, Zarate CA Jr, and Gould TD (2018b) Convergent mechanisms underlying rapid antidepressant action. CNS Drugs 32:197-227.

Zanos P and Gould TD (2018c) Mechanisms of ketamine action as an antidepressant. Mol Psychiatry 23:801-811.

Zanos P, Moaddel R, Morris PJ, Georgiou P, Fischell J, Elmer GI, Alkondon M, Yuan P, Pribut HJ, Singh NS, et al. (2016) NMDAR inhibition-independent antidepressant actions of ketamine metabolites. Nature 533:481-486.

Zanos P, Moaddel R, Morris PJ, Georgiou P, Fischell J, Elmer GI, Alkondon M, Yuan P, Pribut HJ, Singh NS, et al. (2017a) Zanos et al. reply. Nature DOI: 10.1038/ nature22085.

Zanos P, Moaddel R, Morris PJ, Georgiou P, Fischell J, Elmer GI, Alkondon M, Yuan P, Pribut HJ, Singh NS, et al. (2017b) Zanos et al. reply. Nature 546:E4-E5.

Zanos P, Moaddel R, Morris PJ, Wainer IW, Albuquerque EX, Thompson SM, Thomas CJ, Zarate CA Jr, and Gould TD (2017c) Reply to: antidepressant actions of ketamine versus hydroxynorketamine. Biol Psychiatry 81:e69-e71.

Zarate CA Jr, Brutsche N, Laje G, Luckenbaugh DA, Venkata SL, Ramamoorthy A, Moaddel R, and Wainer IW (2012a) Relationship of ketamine's plasma metabolites with response, diagnosis, and side effects in major depression. Biol Psychiatry 72:331-338.

Zarate CA Jr, Brutsche NE, Ibrahim L, Franco-Chaves J, Diazgranados N, Cravchik A, Selter J, Marquardt CA, Liberty V, and Luckenbaugh DA (2012b) Replication of ketamine's antidepressant efficacy in bipolar depression: a randomized controlled add-on trial. Biol Psychiatry 71:939-946. 
Zarate CA Jr, Singh JB, Carlson PJ, Brutsche NE, Ameli R, Luckenbaugh DA, Charney DS, and Manji HK (2006) A randomized trial of an N-methyl-D-aspartate antagonist in treatment-resistant major depression. Arch Gen Psychiatry 63:856-864.

Zeilhofer HU, Swandulla D, Geisslinger G, and Brune K (1992) Differential effects of ketamine enantiomers on NMDA receptor currents in cultured neurons. Eur $J$ Pharmacol 213:155-158.

Zhang C, Tang WK, Liang HJ, Ungvari GS, and Lin SK (2018) Other drug use does not impact cognitive impairments in chronic ketamine users. Drug Alcohol Depend 186:1-8. Zhang JC, Li SX, and Hashimoto K (2014) R (-)-ketamine shows greater potency and longer lasting antidepressant effects than S (+)-ketamine. Pharmacol Biochem Behav 116:137-141.

Zhang K, Xu T, Yuan Z, Wei Z, Yamaki VN, Huang M, Huganir RL, and Cai X (2016) Essential roles of AMPA receptor GluA1 phosphorylation and presynaptic HCN channels in fast-acting antidepressant responses of ketamine. Sci Signal 9:ra123.
Zhao X, Venkata SL, Moaddel R, Luckenbaugh DA, Brutsche NE, Ibrahim L, Zarate CA Jr, Mager DE, and Wainer IW (2012) Simultaneous population pharmacokinetic modelling of ketamine and three major metabolites in patients with treatment-resistant bipolar depression. Br J Clin Pharmacol 74:304-314.

Zhao Y and Sun L (2008) Antidepressants modulate the in vitro inhibitory effects of propofol and ketamine on norepinephrine and serotonin transporter function. $J$ Clin Neurosci 15:1264-1269.

Zhou W, Wang N, Yang C, Li XM, Zhou ZQ, and Yang JJ (2014) Ketamine-induced antidepressant effects are associated with AMPA receptors-mediated upregulation of $\mathrm{mTOR}$ and BDNF in rat hippocampus and prefrontal cortex. Eur Psychiatry $\mathbf{2 9}$ $419-423$.

Zhou ZS and Zhao ZQ (2000) Ketamine blockage of both tetrodotoxin (TTX)-sensitive and TTX-resistant sodium channels of rat dorsal root ganglion neurons. Brain Res Bull 52:427-433. 


\section{Correction to "Ketamine and Ketamine Metabolite Pharmacology: Insights into Therapeutic Mechanisms"}

In the above article [Zanos Z, Moaddel R, Morris PJ, Riggs LM, Highland JN, Georgiou P, Pereira EFR, Albuquerque EX, Thomas CJ, Zarate CA, and Gould TD (2018) Pharmacol Rev 70(3):621-660; doi: https://doi.org/10.1124/pr.117.015198], was originally published under copyright by The American Society for Pharmacology and Experimental Therapeutics. The paper is U.S. Government work not protected by U.S. copyright. The article has been corrected to display the correct copyright in the HTML and PDF versions.

The compositor regrets this error and any inconvenience it has caused. 